\title{
THE EUROPEAN COMMUNITY ARBITRATION COMMISSION ON YUGOSLAVIA*
}

\author{
By MATTHEW C. R. CRAVEN
}

\section{INTRODUCTION}

At a meeting in Brussels on 27 August 1991 , the European Community and its Member States agreed to convene an International Conference for Peace in Yugoslavia with a view to finding a permanent and pacific solution to the crisis within the Socialist Federal Republic of Yugoslavia (SFRY) which had resulted in conflict.' Those to attend the opening session in The Hague were the Federal Presidency and Federal Government of Yugoslavia, the Presidents of the six Republics, the President of the EC Council and representatives of the EC Commission and EC Member States. ${ }^{2}$ With a view to finding 'a peaceful accommodation of the conflicting aspirations of the Yugoslav peoples', it was decided that an Arbitration Commission should be created in the framework of the Conference' 3 to which 'the relevant authorities will submit their differences'. ${ }^{4}$

The Arbitration Commission so created delivered ten 'opinions' between December 1991 and July 1992.5 Opinions $1-3$ and 8-10 were delivered in response to questions formulated by the Chairman of the EC peace conference, and Opinions 4-7 on the initiative of the Council of Ministers of the EC. It also rendered an 'interlocutory decision' prior to its eighth opinion following Serbia and Montenegro's challenge to its

* (1) Dr Matthew C.R. Craven, rg96.

\$ Lecturer in Law, University of Leicester.

1 Joint Statement, 28 August $199 \mathrm{t}$, Bulletin of the $E C, 24$ (I991), no. 7/8, p. 115, s. 1.4.25. It was stated (p. 116): "The Community and its member States cannot stand idly by as the bloodshed in Croatia increases day by day. An agreement on the monitoring of the cease-fire and its maintenance should allow the Community and its. Member States to convene a peace conference and establish an arbitration procedure.'

Ibid.

3 Joint Statement, 3 September 1991, Bulletin of the EC, 24 (1991), no. 9, p. 63, s. 1.4.1. The idea of creating a European Court of Conciliation and Arbitration had been advanced earlier by Robert Badinter, President of the French Constitutional Court: see note, La Monde, 21 June 1991.

+ Joint Statement, loc. cit. above (n. r).

5 In total, the Commission issued fifteen opinions: Opinion No. 1, International Legal Materials, 31 (1992), p. 1494; Opinion .No. 2, ibid., p. 1497; Opinion No. 3, ibid., p. 1499; Opinion No. 4, ibid., p. 1501; Opinion No. 5, ibid., p. 1503; Opinion No. 6, ibid., p. 1507; Opinion No. 7, ibid., p. 1512; Opinion No. 8, ibid., p. 1521; Opinion No. 9, ibid., p. 1523; Opinion No. 10, ibid., p. 1525. 
competence. ${ }^{6}$ In January 1993 the Arbitration Commission was 'reconstituted', its composition and terms of reference being revised and clarified. ${ }^{7}$ In that form, the Arbitration Commission delivered a further five opinions (Opinions I 1-1 5). ${ }^{8}$ Since 1993, although the Conference of Yugoslavia has still been operating, ${ }^{9}$ the Commission has not been asked to deliver any further opinions on matters arising.

The fifteen opinions delivered by the Arbitration Commission represent an important and unusual range of opinions on a variety of questions of international law relating to statehood and succession. Rarely has it been the case that a body of legal experts has been asked to deliver a series of apparently abstract opinions on the international legal dimensions of the dismemberment of a single State. In a formal sense, the opinions of the Arbitration Commission are not binding on any of the States concerned. The Commission was not created in virtue of an international arbitration agreement between disputing parties, and had no treaty base. Rather, it was an executive creation on the part of the EC and its Member States acting through the medium of the Conference on Yugoslavia. Its opinions were directed not to the parties concerned but to the Conference itself, and were delivered in a consultative capacity. ${ }^{\circ}$ Nevertheless, as has been made clear with respect to the International Court of Justice (ICJ), advisory opinions delivered by independent judicial bodies have considerable moral and political authority, and while not having the effect of res judicata may be declaratory of general international law." Even if the Arbitration Commission cannot strictly be seen as an 'independent judicial body', it was certainly independent of the disputing parties, it attempted to conduct its activities in a broadly judicial manner, and it sought to found its opinions in general international law. As such, its opinions may be treated as non-binding but authoritative statements of the relevant law.

Ultimately, the significance of the Arbitration Commission's opinions may be appreciated in two ways. First, the opinions served to provide a

"Interlocutory Decision, ibid., p. 1518.

- International Legal Materials, 32 (1993), p. 1572.

*Opinion No. 11, ibid., p. 1586; Opinion No. 12, ibid., p. 1589; Opinion No. 13, ibid., p. 1591 ; Opinion No. 14, ibid., p. 1593 ; Opinion .No. 15, ibid., p. 1595.

- See Reports of Co-Chairmen of the Steering Committee of the International Conference on the Former Yugoslavia, S/1994/1074, ig September 1 994; S/1994/1124, 3 October 1994; S/1 1994/1246, 3 November 1994; S/1 994/1372, I December 1994; S/1994/1454 29 December 1994; S/1994/811, 8 July 1994; S/r994/83, 26 January 1994; S/1995/175, 2 March 1995; S/1995/302; S/1995/6, 5 January 1995. Reports of the Secretary-General on the International Conference on Yugoslavia: $\mathrm{S} / 24795$, II November 1992; S/25015, 24 December 1992; S/25050, 6 January 1993; $S / 25100$, Annex, 14 January 1993; S/25221, 2 February 1993; S/25708, 30 April 1993; S/25709, 3 May 1993.

10 Below, nn. 78-85.

"See separate opinion of Judge Azevedo in the Peace Treaties case, ICJ Report, 1950, p. 79, at p. 80 . In the same case Judge Zoricic noted that 'in practice, an advisory opinion given by the Court in regard to a dispute between States is nothing else than an unenforceable judgment': ibid., p. 1or. Cf. Article $38(1)(d)$. Statute of the ICJ. 
legal rationalization for elements of State practice that were otherwise contradictory or incoherent. For example, its view that in the dismemberment of the SFRY the principle of uti possidetis juris should be applied to 'internationalize' former administrative boundaries 12 essentially followed earlier statements of the EC Member States to the effect that they would 'never recognize changes of [former internal] frontiers which have not be brought about by peaceful means and by agreements'. ${ }^{3}$ Secondly, the Commission's opinions also had a proactive dimension, in that they provided a legal framework for the development of subsequent State practice. For example, the EC and its Member States, in refusing to accept the new Federal Republic of Yugoslavia (FRY) as the sole successor to the former Socialist Federal Republic of Yugoslavia (SFRY), expressly referred to the Arbitration Commission's conclusions in Opinion No. 10." The view that the SFRY underwent a process of dismemberment ${ }^{15}$ was also undoubtedly influential as regards the United Nations' determination that the FRY should not continue automatically the membership of the former SFRY in the UN. " In fact the influence exerted by the opinions of the Arbitration Commission became a point of issue as far as the FRY was concerned, which complained that in practice the advisory opinions 'were taken as judgments and served as a basis for making concrete decisions on relevant issues concerning the Yugoslav crisis'. ' 7

It should be noted, however, that the opinions of the Arbitration Commission were not entirely determinative of State practice. Despite its findings to the contrary, EC Member States proceeded to recognize Croatia as an independent State and at the same time refused to give diplomatic recognition to the Republic of Macedonia. ${ }^{8}$ As will be seen, however, this was largely due to the fact that on the issue of recognition, the Arbitration Commission was acting as a fact-finding body and its opinions were treated merely as a matter of information. In any case, it is apparent that the main elements of the Commission's opinions broadly corresponded with State practice and provided a legal framework for the precarious territorial and political settlement that was ultimately imposed upon the former Yugoslavia.

12 Below, n. 307.

1" Joint Statement, loc. cit. above (n. I). While the principle outlined by the EC might have been acceptable as regards existing international frontiers, it was highly unusual in so far as it referred to a situation which was at the time prima facie internal. See Weller, "The International Response to the Dissolution of the Socialist Federal Republic of Yugoslavia', American Yournal of Intermational Law, 86 (1992), p. 569, at pp. 575-6.

it Statement of EC Member States, 22 September 1992, this Year Book, 63 (1992), p. $65^{8}$.

is Opinion No. 8, loc. cit. above (n. 5), p. 1523.

16 SC Resn. 777, 19 September 1992.

17 Letter from the Deputy Prime Mlinister and Minister for Foreign Affairs of the FRY addressed to the ICFY Co-Chairmen, 2 July 1993. International Legal Materials, 32 (1993), p. 1584 .

is Below, nn. 257-8. 


\section{The Arbitration Commission'9}

\section{I. Membership}

Under its initial mandate, the Arbitration Commission was to consist of five members, three of whom were to be appointed by the EC and its Member States, and the other two by the Yugoslav Federal Presidency. ${ }^{20}$ The EC and its Member States accordingly designated the President of the French Conseil Constitutionnel (Robert Badinter), the President of the German Federal Constitutional Court (Roman Herzog) and the President of the Italian Constitutional Court (Aldo Corasaniti). The Yugoslav Federal Presidency, however, was unable to come to a unanimous agreement on the proposed candidates. This possibility had been specifically foreseen in the Commission's terms of reference, which had provided that where no agreement was possible on the appointment of the Yugoslav members, they would be chosen by the other three members." Accordingly the final two members were appointed, and were the President of the Spanish Constitutional Court (Francisco Tomas y Valiente) and the President of the Belgian Cour d'Arbitrage (Irène Petry). At its first session, M. Badinter was appointed as the President of the Commission, and it was decided that the Commission would continue to sit in Paris. It also adopted a set of rules of procedure which were not made public. ${ }^{22}$

When the EC Arbitration Commission was reconstituted in January 1993 its composition was similarly changed. As previously, it was determined that the Arbitration Commission should be composed of five permanent members: three to be designated by the Council of Ministers of the EC from among incumbent Presidents of Constitutional Courts of the existing Member States or from members of the highest courts of

19 See generally Pellet, 'Vote Sur la Commission d'Arbitrage de la Conférence Européenne Pour la Paix en Yugoslavie', Annuaire franfais de droit international, 37 (1991), p. 329; id., 'L'Activité de la Commission d'Arbitrage de la Conférence Européenne Pour la Paix en Yugoslavie', ibid., 38 (1992), p. 220; id., 'L'Activitié de la Commission d'Arbitrage de la Conférence Européenne Pour la Paix en Yugoslavie', ibid., 39 (1993), p. 286; Regazzi, 'Introductory Note', International Legal Materials, 31 (1992), p. 1488.

20 Joint Statement, loc. cit. above (n. 1).

21 Ibid.

*2 Pellet describes the working methods as follows:

'cette procédure est demeurée extrêmement souple, informelle et discrète. Sur chaque problème, un rapporteur a été assuré par l'envoi . . . à chacune des parties intéressées des documents émanant des autres parties. En revanche, la Commission a refusé de donner suite aux demands d'audience qui lui ont été transmises, et, bien qu'elle ait envisagé la possibilité de désigner des délégués mandatés collectivement pour se rendre sur place à fin d'information et d'instruction, elle n'a jamais utilisé cette procédure.

De même, bien qu'elle eût prévu que ses recommandations seraient adoptées à la majorité simple des voix sans possibilité d'abstention $n$ i indication sur le sens du vote des members qui, cependant, pourraient publier, le cas échéant, des opinions dissidentes, elle a arrêté ses positions par consensus.'

(Loc. cit. above (n. 19) (1991), p. 332.) 
those States; ${ }^{23}$ the fourth member was to be designated by the President of the ICJ from among the former members of that Court or persons possessing the qualifications required by Article 2 of the Statute of the Court; the final member was to be a member of the European Court of Human Rights, designated by the President of that Court. It was further stipulated that no two members were to have the same nationality and that each member 'is to serve as long as he or she holds the office on the basis of which the designation is made'. ${ }^{24}$ In addition to the permanent members of the Arbitration Commission, it was provided that in contentious proceedings, the contending parties would each be entitled to appoint an ad hoc member to the Commission. The ad hoc members should either be incumbent members of Constitutional Courts or highest courts in existing Member States of the CSCE or qualify in the same manner as the fourth and fifth permanent members of the Commission.

Pursuant to the terms of reference of the Commission, and in light of the responses provided by the Presidents of the ICJ and European Court of Human Rights, the initial composition of the Commission was as follows: Robert Badinter (President of the Constitutional Court of France), Francisco Paolo Casavola (President of the Constitutional Court of Italy), Roman Herzog (President of the Constitutional Court of Germany), Elizabeth Palm (Judge of the European Court of Human Rights), Jose Maria Ruda (former President of the ICJ). The Arbitration Commission's competence with respect to contentious proceedings was never invoked and therefore no ad hoc members were ever appointed to sit upon the Commission.

\subsection{The Constitution of the Arbitration Commission}

The legal basis of the Arbitration Commission is to be found initially in the EC Declaration of 27 August 1991. In that Declaration the EC and its Member States, together with the various parties to the Yugoslav crisis, resolved to create an arbitral procedure in the framework of the peace Conference' with a view to considering 'differences' submitted by ' $[t]$ he relevant authorities'. ${ }^{25}$ It was further resolved that ' $[t]$ he relevant authorities will submit their differences to an arbitration Commission of five members'. ${ }^{26}$

These initial terms of reference fall considerably short of what one would usually expect of an arbitral procedure. As the International Law Commission's Model Rules on Arbitral Procedure suggest, the terms of

\footnotetext{
Italy.

$2+$ Ibid.

xs Joint Statement, loc. cit. above (n. 1), p. I 16 .

2" Ibid.
} 
a compromis should indicate as a minimum ' $(a)$ the undertaking to arbitrate according to which the dispute is to be submitted to the arbitrators; $(b)$ the subject-matter of the dispute and, if possible, the points on which the parties are or are not agreed; $(c)$ the method of constituting the tribunal and the number of arbitrators' ${ }^{27}$ In addition, it suggested that a number of other provisions deemed desirable by the parties might be indicated, such as the rules of law to be adopted by the tribunal, the procedure to be followed, the majority required for the award, the time limit within which the award should be made and the languages to be employed in the proceedings. ${ }^{28}$ As far as the Arbitration Commission was concerned, all that was made utterly clear was the composition of the Commission. In terms of the undertaking to arbitrate, the identity of the parties to the dispute, and the subject-matter(s) covered by the procedure, there remained a number of questions to be resolved. Before addressing such questions, it is worth considering what might have been intended by the parties concerned in specifically creating what they termed to be an 'Arbitration Commission'.29

Arbitration is traditionally understood as meaning 'the settlement of disputes between States by judges of their own choice and on the basis of respect for law'. ${ }^{30}$ 'The two dimensions of arbitration highlighted by this definition, which set it apart from other forms of international dispute settlement, are, on the one hand, the need for the consent of States at every stage of the arbitration process (including the right to choose their own judges ${ }^{31}$ ) and, on the other hand, the legal nature of the award. ${ }^{32}$ Arbitration may thus be distinguished from other forms of diplomatic settlement such as conciliation, ${ }^{33}$ mediation $^{34}$ or negotiation, ${ }^{35}$ in virtue

${ }^{27}$ General Assembly Official Records, $13^{\text {th }}$ Session, Supplement No. 9, Doc. A/3859, pp. 5-8 $(1958)$.

2A Ibid., Article 2.

19 It should be noted, nevertheless, that denomination alone cannot be determinative. That a body is specifically referred to as an 'Arbitration Commission' does not necessitate that it is to engage in arbitration in the proper sense.

30 Article 15, Hague Convention 1899; Article 37, Hague Convention 1907. The International Law Commission similarly defined arbitration as 'a procedure for the settlement of disputes between States by a binding award on the basis of law and as a result of an undertaking voluntarily accepted': Yearbook of the ILC, 1953, vol. 2, p. 202.

"Johnson, "The Constitution of an Arbitral Tribunal', this Year Book, 30 (1953), p. 152.

3 See Fox, 'Arbitration', in International Disputes: The Legal Aspects (1972), p. 101, at pp. $101-2$.

${ }_{33}$ Merrills describes conciliation as: 'a method for the settlement of international disputes of any nature according to which a commission set up by the parties, either on a permanent basis or an ad hoc basis to deal with a dispute, proceeds to the impartial examination of the dispute and attempts to define the terms of a settlement susceptible of being accepted by them or affording the Parties, with a view to its settlement, such aid as they may have requested': International Dispute Settlement (2nd edn., 1991), p. 59. It is clearly open for judicial tribunals, such as the ICJ, to undertake a conciliatory function: see North Sea Continental Shelf cases, $I C \mathcal{J}$ Reports, 1969, p. 3. See also Fox, 'Conciliation', in International Disputes: The Legal Aspects (1972), p. 93.

3+ Darwin, 'Mediation and Good Offices', in International Disputes: The Legal Aspects (1972), p. 83 .

3s Darwin, 'Negotiation', in International Disputes: The Legal Aspects (1972), p. 77. 
of the fact that in cases of arbitration, the parties are obliged to accept the award as binding. ${ }^{36}$ That arbitration is essentially a legal task has certain consequences for the composition and functioning of the arbitral body. The arbitral body must proceed strictly within its terms of reference and must respect the rules of natural justice. The judicial character of the body was stressed, for example, by the PCIJ in the Interpretation of Article 3, Paragraph 2, of the Treaty of Lausanne case, where it found that because of its political composition it was 'impossible, properly speaking, to regard the Council, acting in its capacity of an organ of the League of Nations ... as a tribunal of arbitrators' ${ }^{37}$ Despite the similarities in function, arbitration is also usually distinguished from judicial settlement. As has frequently been noted, however, no clear-cut distinction can be made, the differences lying more in terms of typological characteristics ${ }^{38}$ such as the relative permanence of the tribunal ${ }^{39}$ and the degree of control exercised by the disputing parties over its composition and procedure..$^{\circ}$

Given that the Arbitration Commission was to be composed of jurists appointed by the EC and its Member States on the one hand, and the Yugoslav Federal Presidency on the other, one might assume that the Commission was created to arbitrate on disputes arising between those parties. That of course was never the intention, it being clear from the fact that the Arbitration Commission was created within the framework of the Conference on Yugoslavia that the disputes to which it would address itself were those arising from the conflict within the SFRY following the attempted secession of Croatia and Slovenia. This raises a number of significant problems as regards both the characterization of the procedure and the application of legal principle.

The first, and most obvious, problem relates to the legal status of the disputing parties. Even on the most optimistic analysis, ${ }^{+1}$ the statehood of Croatia and Slovenia can only clearly be established once the threemonth suspension of their declarations of independence came to an end

3n Article 37 of the 1907 Hague Convention adds to the definition: 'Recourse to arbitration implies an engagement to submit in good faith to the award'.

37 Advisory opinion, PCIF, Series B, No. 12, at p. 26 (1925).

${ }^{3 *}$ Brownlie cites the following factors as being influential in designating a tribunal as an 'arbitral tribunal': (i) if the compromis is likely to allow settlement on extra-legal principles; (ii) if the agency of decision is designated as an 'arbitral tribunal'; (iii) if the tribunal consists of an odd number and includes representatives from the disputing States; (iv) if the tribunal is merely created to deal with a particular dispute, or class of disputes; $(v)$ if there is flexibility in the procedures: Brownlie, Principles of Public International Law (4th edn., 1990), p. 710.

39 Merrills, op. cit. above (n. 33), p. 80.

40 Schwarzenberger notes that the only difference between arbitration and judicial settlement lies in the method of selecting the members of these judicial organs. While, in arbitration proceedings, this is done by agreement between the parties, judicial settlement presupposes the existence of a standing tribunal with its own bench of judges and its own rules of procedure which parties to a dispute must uccept": Manual of Intermational Law (6th edn., 1976), p. 195.

4 Below, nn, 252-6i. 
on 8 October $1991 .^{+2}$ As regards the other Republics, their acquisition of statehood occurred somewhat later (up to nine months later in the case of the Federal Republic of Yugoslavia). ${ }^{43}$ Accordingly, it appears that the Arbitration Commission was not intended to arbitrate on differences between 'States' as such, but rather, non-State actors. ${ }^{44}$ 'This much, at least, was implicitly recognized in the terms of its mandate, which referred opaquely to the 'relevant authorities' between which the Commission was to arbitrate. ${ }^{45}$ Having said that, it cannot have been far from the minds of those involved in the creation of the Commission that at least some of the Republics were likely to acquire independent statehood in the foreseeable future and that questions of public international law were therefore likely to arise.

The very real difficulty facing the Conference was therefore providing a legal basis for the jurisdiction of the Commission. Arbitration, as a procedure for settling disputes in national or international law, is always constructed on the basis of a compromis - a binding agreement between two parties (either on an ad hoc or a general basis ${ }^{46}$ ) to submit a dispute to the jurisdiction of an arbitrator or an arbitration tribunal. If the agreement were solely founded in Yugoslav law, it would not sufficiently deal with matters relating to the acquisition of statehood and subsequent issues of statehood. Similarly, if the agreement were founded in international law, it could only bind the Republics themselves in so far as they were deemed to have international personality as States in statu nascendi, ${ }^{47}$ and only to the extent that they were deemed to have consented to the procedure.

In the event, the agreement on arbitration was essentially contained in the Declaration adopted by the Conference on Yugoslavia. Although it was approved by all the participants of the Conference, it cannot readily be seen as a treaty or other form of binding commitment. Rather, it

42 See Opinion No. 11 , loc. cit. above (n. 8), p. 1588 .

43 This assumes, of course, that the FRY is not the continuation of the SFRY: below, $\mathrm{nn} .224-32$.

44 That, at the time of the creation of the arbitration procedure, the situation was essentially internal to the SFRY, was in some respects reflected in the composition of the Arbitration Commission. The Arbitration Commission in the first instance contained judges from constitutional courts across Europe, suggesting that the lex arbitri was intended to be Yugoslav law and that the Commission was to enquire inter alia into the legitimacy and effects of the secession of Slovenia and Croatia under the Yugoslav Constitution.

is It was open to question whether the leaders of the Serbian enclave within Croatia (which had constituted itself as the Serbian Autonomous Republic of Krajina) could have been considered 'relevant authorities' for the purposes of the dispute settlement procedure.

${ }_{40}$ The difference between $a d h o c$ and general compromis is that in the latter case, States agree to submit all or definite classes of disputes to a tribunal (usually an arbitral institution). In the latter case, there is usually the need for a further 'special agreement' or 'implementing compromis' to outline the details of the procedure to be adopted and the issues that the tribunal is to deal with. See Oellers-Frahm, 'Compromis', in Encyclopaedia of Public International Law, vol. 1 (1991), p. 712.

47 See Crawford, The Creation of States in International Law (1979), pp. 39:-6; Brownlie, op. cit. above (n. 38$)$, p. 79 . 
appears to be in the form of a 'gentleman's agreement' incorporating a declaration of intention or preliminary agreement to submit disputes to arbitration. As Pellet suggests of the Declaration creating the Commission, '[i]l s'agit ... d'un acte concerté non conventionnel sans valeur juridique obligatoire' ${ }^{+8}$ Thus, although there was nothing to prevent the EC creating an Arbitration Commission pursuant to the Declaration, the 'relevant parties' were in no sense obliged to submit their differences to it. ${ }^{+9}$ Indeed, it is likely that were they to do so, a further 'implementing compromis' would be necessary in order to lay down the details of the procedure to be followed, or at least the expression of ad hoc consent.

The initial terms of reference of the Arbitration Commission were supplemented in a joint statement of 3 September 1991 , which specified that the Chairman of the EC Peace Conference would transmit to the Arbitration Commission the issues submitted for arbitration, and that the results of the Commission's deliberations would then be returned to the Peace Conference through its chairman. ${ }^{50}$ The intercession of the Chairman of the Peace Conference in the arbitration procedure would not be significant if he merely represented a channel of communication. It would, however, significantly alter the nature of the procedure if the Chairman were to involve himself, as he later did, in determining the questions that were ultimately to be addressed by the Commission. ${ }^{51}$ In the latter case, the Commission would find itself in the position not of arbitrating between two parties, but rather of delivering a legal opinion to the Conference as an advisory organ.

In fact, of its first ten opinions, six resulted from references to the Commission by the Chairman of the Peace Conference (Lord Carrington), two of which had been initiated by Serbia but were redrafted by the Chairman. The other four (relating to the conditions for recognition) were referred to the Commission by the Council of Ministers of the EC. That the Commission considered itself obliged to respond to the request of the Council to deliver opinions on the diplomatic recognition of the Republics lends some ambiguity as to the States or institutions to which it was responsible. Indeed, what serves to confuse matters is that the creation of the Commission was in effect initiated under the auspices of the EC in an extraordinary ministerial meeting of the Council of

4* Pellet, loc. cit. above (n. 19) (1991), p. 331.

4\% This is the case irrespective of the fact that the Declaration provides that the relevant authorities 'will submit their differences' to the Arbitration Commission (emphasis added): Joint Statement, loc. cit. above (n. I).

50 Interlocutory Decision, loc. cit. above (n. 6), p. 1520.

5. Cf. Schwebel, 'Was the Capacity to Request an Advisory Opinion Wider in the Permanent Court of International Justice than it is in the International Court of Justice?', this Year Book, 62 (1991), p. 77. 
Ministers ${ }^{52}$ and that it was funded primarily from the EC budget. ${ }^{53}$ It would appear nevertheless that the Commission was not intended to be an organ of the Community, but rather one of the Peace Conference as a separate entity. Its response to the request of the EC for opinions may presumably be explained by the fact that the EC and its Member States were members of the Conference. As will be seen below, however, many of the confusions that attached to the Arbitration Commission's initial terms of reference were subsequently remedied when its constitution was revised and clarified on 27 January $1993 .{ }^{5+}$ That initiative was undoubtedly prompted by the first of two challenges that were raised by the FRY against the jurisdiction of the Commission.

\subsection{The First Challenge to Furisdiction ${ }^{55}$}

The competence of the Commission to render 'opinions' on issues put before it by the Chairman of the Commission and the Council of Ministers of the EC went unchallenged for the first seven of its fifteen opinions. When it came to deal in detail with issues relating to the terms of succession in June 1992, however, its competence was challenged by Serbia and Montenegro. The Chairman of the Arbitration Commission was informed by the Presidents of Montenegro (Momir Bulatovic) and Serbia (Slobodan Milosevic) that they challenged the Commission's competence to give an opinion on the latest three questions (which were to form Opinions 8-10) submitted to it by the Chairman of the Conference for Peace in Yugoslavia. ${ }^{56}$ They contended that: (i) the questions did not fall within the mandate given to the European Community under the terms of the Brioni agreement; (ii) that outstanding matters between the various Republics should be resolved by

\footnotetext{
32 The Community and its Member States convened the Conference 'under their aegis'. They agreed to 'ensure the Chairmanship of the Conference' and stipulated that the proceedings would be 'conducted on their behalf by a Chairman on the basis of a mandate from them': Joint Statement, loc. cit. above (n. 3).

53 Pellet notes that "[d]ès sa première réunion, la Commission décida d'ailleurs que "le relevé des frais engagés (voyages, traductions, fais de téléphone et de télécopie) serait centralisè à Paris et transmis ultérieurement à fins de remboursement à l'organe compétent de la Communauté", en l'espèce la Présidence'; Pellet, loc. cit. above (n. 19) (1991), p. 332.

34 Note on Composition and Terms of Reference, International Legal Materials, 32 (1993), p. 1573 .

ss 'The terms 'jurisdiction' and 'competence' have been used loosely in the practice of the ICJ. Here, the approach advocated by Fitzmaurice will be used, namely, to use 'jurisdiction' as a term associated with the tribunal's entire jurisdictional field ratione materiae, personae or temporis; and 'competence' as the tribunal's capacity to determine a particular case: see Fitzmaurice, 'The Law and Procedure of the International Court of Justice', this Year Book, 34 (1958), p. 5, at pp. 8-9. Cf. Rosenne, The Law and Practice of the Intemational Court (and edn, 1985), pp. 296-304; Pratap, The Advisory Furisdiction of the International Court (1972), pp. $113^{-1} 5$.

so Interlocutory Decision, loc. cit. above (n. 6), p. 1518 .
} 
means of an overall agreement; and (iii) that those questions that could not be resolved by agreement should be submitted to the ICJ. ${ }^{57}$

These points were addressed by the Commission in what was termed an 'interlocutory decision' before going on to consider the questions that became the subject of Opinions 8 to 10 . The first issue to be dealt with by the Commission in its interlocutory decision was whether it was in fact able to pronounce upon its own competence in the case at hand (the compétence de la compétence). This matter had been specifically contested by Serbia and Montenegro ${ }^{58}$ which apparently considered that the jurisdiction of the Commission had to be determined by the parties to the arbitration proceedings rather than by the Commission itself. ${ }^{59}$ The Commission initially pointed out that it had been established, not as Serbia and Montenegro had suggested under the Brioni Agreement of 7 July $1991,{ }^{60}$ but by the joint statement on Yugoslavia adopted on 27 August $199 \mathrm{I} .{ }^{6}$ It also noted that the arrangements set out in that document, although summary in nature, had been accepted by the six Yugoslav Republics. Moreover, it was clear "from the terminology used and even the composition of the Commission that the intention was to create a body capable of resolving on the basis of law the differences which were to be submitted to it by the parties'."2 This, as the Commission argued, 'precisely constitutes the definition of arbitration' as defined by the ICJ in the Arbitral Award of 31 Y 4 uly I 989 case (1991).6.3 It followed that since the Commission was an arbitral tribunal properly so-called, it was therefore competent to determine its own jurisdiction. Recalling the dicta of the ICJ in the Nottebohm case (Preliminary

s7 Ibid., p. 15 r 9 .

s\$ Ibid.

5) There is some evidence in the Commission's decision that Serbia's objection on this point was itself the subject of objections by other Republics, the Commission considering it necessary to ascertain its competence 'independent of any dispute on this point' and without considering the 'admissibility of [the] preliminary objections': ibid. See also Pellet, loc. cit. above (n. 19) (1992), p. 223.

to The Brioni Agreement, brokered by the EC, provided inter alia for the withdrawal of JNA forces from Slovenia in return for the suspension of the implementation of Croatia's and Slovenia's declarations of independence for a period of three months: Keesing's Record of World Erents (hereinafter Keesing's), vol. 37, p. 38374 (1991).

") The source of Serbia and Montenegro's confusion on the point is unclear: the Brioni Agreement itself made no mention of the Conference on Yugoslavia, let alone the Arbitration Commission that was later to be set up.

t. Interlocutory Decision, loc. cit. above (n. 6), p. 1519.

"3 ICJ Reports, 1991 , p. 50. In that case the ICJ made the following point:

‘. when states sign an arbitration agreement, they are concluding an agreement with a very specific object and purpose: to entrust an arbitration with the task of scttling a dispute in accordance with the terms agreed by the parties, who define in the agreement the jurisdiction of the tribunal and determine its limits. In the performance of the task entrusted to it, the tribunal "must conform to the terms by which the Parties have defined this task":

(Ibid., p. 70.) It may be noted that this definition is not 'precisely' that advanced by the Arbitration Commission, in that it makes no mention of the legal nature of the issues to be decided. 
Objection), ${ }^{64}$ the Commission noted that this was a principle of international law that had been generally accepted in the field of arbitration 'since the Alabama case'. ${ }^{65}$

On this initial point the reasoning of the Commission is largely opaque and even confused. Although it is generally accepted that international tribunals have an inherent power to determine their own jurisdiction, ${ }^{66}$ it is doubted whether the reasoning pursued by the Commission to establish this point is sound. The Commission suggested that this competence derived from its position as an arbitral tribunal. It is clear, as the ICJ suggested, that in cases where parties to a dispute refer the matter to arbitration by means of a compromis, the tribunal must be deemed to possess, de minimis, the competence to interpret the terms of the compromis unless specifically excluded from doing so. ${ }^{67}$ If it were otherwise, the very object of arbitration would be defeated. ${ }^{68}$ However, as suggested above, the Commission's initial mandate was not so much a compromis agreed between disputing States, with binding force under international law, as a declaration of intention on the part of the participating entities. In the absence of a further agreement between the disputing parties to submit the matter to the Commission for arbitration, it cannot be said that the Commission based its jurisdiction on the consent of the parties concerned. In fact, as the Commission later came to recognize, its role was rather one of delivering advisory opinions to the Conference from its position as a consultative organ. ${ }^{69}$

The Arbitration Commission, having established its power to determine jurisdictional issues, turned to examine its competence as regards the three questions submitted to it by the Chairman of the Peace Conference. In doing so, the Commission advanced two arguments in

it ICY Reports, 1953, p. 4.

o5 Ibid., p. I 19.

so See Fitzmaurice, loc. cit. above (n. 55), pp. 25-8. The competence of the ICJ in this regard is founded in Article $36(6)$ of the Statute of the ICJ, which provides that a dispute as to whether the Court has jurisdiction shall be settled by the Court. This is applicable to advisory cases by virtue of Article 68 of the Statute. See Pratap, op. cit. above (n. 55), p. 117.

"I In doing so, an arbitral tribunal may consider both the intentions of the parties and the rules of law to be applied: Rio Grande Irrigation and Land Co. case (1 923), Reports of International Arbitral Awards, vol. 6, p. 13i. The competence of an arbitration tribunal to determine jurisdictional questions is, however, generally limited by the principle extra compromissum arbiter nil facere potest. See Schlochauer, 'Arbitration', in Encyclopaedia of Public Internutional Law, vol. I (1991), p. 215 , at p. 224 .

os See Johnson, loc. cit, above (n. 31 ), p. 160 .

to This point was alluded to by the Arbitration Commission in its interlocutory decision in so far as it referred to the full passage in the Nottebohm judgment which included the following passage: '[the principle that an international tribunal has the right to decide as to its own jurisdiction] assumes particular force when the international tribunal is no longer an arbitral tribunal constitured by virtue of a special agreement between the parties for the purpose of adjudicating on a particular dispute, but is an institution which has been pre-established by an international instrument defining its jurisdiction and regulating its operation': Nottebohm (Preliminary Objection), ICJ Reports, 1953, p. I19. There are, however, difficulties with viewing the position of the Arbitration Commission as being analogous to that of the ICJ in this respect: see below, nn. $113^{-15}$. 
favour of it performing the functions requested. First, it asserted that its competence derived from the consent of the parties as expressed in their participation in the work of the Commission..$^{70}$ Secondly, and implicitly recalling the opinion of the ICJ in the Interpretation of Peace Treaties case, ${ }^{71}$ it argued that its competence derived from its position as an organ of the Conference, in which guise it was under an obligation to deliver an opinion when so requested by the Chairman..$^{72}$ As to the first point, the Commission relied upon the 'practice followed by the Conference ... . and by the responsible authorities in the various Yugoslav Republics' ${ }^{73}$ In that respect it noted that the Republic of Serbia had earlier taken the initiative of submitting three questions to the Conference (two of which had been considered by the Commission and formed Opinions 2 and 3 ), and that none of the Republics had challenged the Commission's competence in that respect. It thereby concluded that the Republics had recognized the Commission's competence 'in consultative issues as well', ${ }^{74}$

In relying upon the imputed consent of the Republics as expressed by their participation in its procedures to ground its competence in the case before it, the Commission apparently comes close to invoking the doctrine of forum prorogatum 75 as operated in the context of the compulsory jurisdiction of the ICJ..$^{76}$ It would seem unlikely, however, that this doctrine could be invoked in the circumstances as the sole basis for the competence of the Commission. First, it is clear that although the Republic of Serbia had actively sought the opinions of the Commission in earlier cases, it had in no way signalled its willingness or desire for the Commission to exercise its competence with respect to the particular issues in hand. 77 Secondly, given that the Republic of Montenegro did not participate to the same extent in the early proceedings of the Commission, it may be questioned whether the FRY could be deemed to be bound by any commitments undertaken by Serbia in that regard. In reality, however, it would appear that the Arbitration Commission was not actually attempting to establish consent to its competence in the case before it, but rather more generally in relation to its role and activity as

70 Interlocutory Decision, loc. cit. above (n. 6), p. 1520.

${ }^{71}$ Interpretation of Peace Treaties zeith Bulgaria, Hungary and Romania, ICJ Reports, 1950, p. 65, at p. 71 .

${ }_{72}$ Interlocutory Decision, loc. cit. above (n. 6), p. 1521 .

73 Ibid., p. 1520.

74 lbid.

75 Sec Corfu Chamel case (UK v. Albania), ICY Reports, 1948, p. 15; H. Lauterpacht, The Developnent of International Law by the International Court (1958), pp. 103-4; Rosenne, op. vit. above (n. 55), pp. 344-63.

$7^{7}$ See Pellet, loc. cit. above (n. 19) (1992), p. 224.

7 Cf. case concerning Application of the Convention on the Prevention and Punishment of the Crime of Genoride (Bosnia and Herzegovina v. Yugoslavia (Serbia and Montenegro)), ICf Reports, 1993, p. 3, at pp. $17-18$ 
a consultative body. In that respect, it is the Commission's second argument that is crucial.

In its second argument, the Arbitration Commission noted that 'it was established in the framework of the Conference for Peace as a body of this Conference' and that '[r]eplying to the questions put by the Chairman of the Conference constitutes Commission participation in the work of the Conference, of which it is a body, and it would require conclusive reasons to bring it to refuse such a request' ${ }^{\prime}{ }^{8}$ It accordingly considered that in the case at hand, it could see "no reason to refuse to perform its functions'. ${ }^{79}$ With respect to this point, it is very clear that the Arbitration Commission had in mind ${ }^{\text {to }}$ the dicta of the ICJ in the Peace Treaties case. ${ }^{81}$ In that case, the ICJ had stated that:

[ $t$ ]he consent of States, parties to a dispute, is the basis of the Court's jurisdiction in contentious cases. The situation is different in regard to advisory proceedings even where the Request for an Opinion relates to a legal question actually pending between States. 'The Court's reply is only of an advisory character: as such, it has no binding force. It follows that no State, whether a Member of the United Nations or not, can prevent the giving of an Advisory Opinion which the United Nations considers to be desirable in order to obtain enlightenment as to the course of action it should take. ${ }^{z_{2}}$

With this passage in mind, it can be assumed that the Commission considered that the apparent lack of consent on the part of the FRY was essentially irrelevant to the exercise of its competence in the case before it. $^{8_{3}}$ At the same time, it is clear that the Arbitration Commission considered itself to have a certain discretion as to whether or not it should exercise its competence: it suggested, in particular, that it might refuse to offer an opinion if there were 'conclusive reasons' for it not to do so. ${ }^{x_{4}}$ This, however, appears to be primarily a question of propriety rather than one of jurisdiction. ${ }^{85}$

78 Interlocutory Decision, loc. cit. above (n. 6), p. 152 I.

7o Ibid.

so This point was later made explicit by the Commission: see Reactions of the Members of the Arbitration Commission of the ICFY to the Statement made by the FRY Government on its Competence, International Legal Materials, 32 (1993), p. 1582, at p. I 583 .

${ }^{*}$. In the Interpretation of Peace Treaties with Bulgaria, Hungary and Ronania, ICF Reports, 1950 , P. 65 .

$\mathrm{x}_{2}$ Ibid, p. 71; Reservations to the Convention on Genocide, ICF Reports, 1951, p. 15, at pp. 19-20.

${ }^{7}$ Peace Treaties case, ibid, p. 70. See also Western Sahara case, ICY Reports, 1975, p. 12. The Arbitration Commission accordingly appears to have adopted the position of the $1 \mathrm{CJ}$ with respect to jurisdiction, rather than that of the PCIJ: see Eastern Carelia case, PCIY, Series B, No. 5 (1923). See generally Rosenne, op, cit. above (n. 55), pp. 698-7 r6; Pomerance, The Advisary Function of the International Court in the League and UN Eras (1973), pp. 279-95; Pratap, op. cit. above (n. 55), pp. $150 \mathrm{ff}$. On the position with respect to the Inter-American Court, see Bucrgenthal, "The Advisory Practice of the Inter-American Human Rights Court', American fournal of International Laze, 79 (1985), p. 1 .

$8_{4}$ Interlocutory Decision, loc. cit. above (n. 6), p. 1521.

*s Pratap, op. cit. above (n. 55), p. 142. He notes later, however, that in the Peace Treaties case, questions of propriety and jurisdiction were somewhat confused: ibid., p. 148 . 
As far as the ICJ is concerned, the exercise of its discretion under Article 65 of the Statute is determined by a number of interrelated desiderata relating to its role as the principal judicial body of the United Nations. Broadly speaking, the main considerations are: (i) that the court should confine its opinions to questions of an essentially legal nature; ${ }^{86}$ (ii) that it should not offer an opinion if to do so would circumvent the principle that a State is not obliged to allow its disputes to be submitted to judicial settlement without its consent; ${ }^{87}$ and (iii) that it should only respond to a request if it relates to matters that fall properly within the field of competence of the requesting organ. ${ }^{88}$ In that the Arbitration Commission clearly considered its advisory jurisdiction to be analogous to that of the ICJ, it is not surprising to find that it addressed some of these points.

As regards the first point, the Commission confirmed that the questions that had been put to it were essentially legal questions and that as such, 'far from constituting an obstacle to the Arbitration Commission's exercising its competence, [it] is, on the contrary, a justification: as the arbitral body of the Conference, the Commission can give a judgement only in law, in the absence of any express authorization to the contrary from the parties, it being specified that in this case it is called upon to express opinions on the legal rules applying' ${ }^{89}$ There is little doubt that the Commission was correct on this point. The questions to which it was asked to respond, while certainly having a political dimension, essentially related to the issues of statehood (the expiration of the SFRY and the emergence of the FRY) and to the principles of succession, and were susceptible to judicial determination. This conclusion is not necessarily affected by the somewhat abstract nature of the questions asked. The Commission might have reached a different conclusion, however, had the point at issue been the substance of Opinions $4-7$, in which the Arbitration Commission had acted primarily as a fact-finding body for the EC and its Member States (in determining whether the four Republics had fulfilled the necessary conditions for recognition).

As regards the second point, it was undoubtedly clear to the Arbitration Commission that the questions it was asked to address related to a legal dispute between States (even possibly to the merits of that

*" Conditions of Admission of a State to Membership in the UN, ICY Reports, 1947-8, p. 57, at p. 61; Certain Expenses case, ICY Reports, 1962, p. 151 . Sce generally Greig, "The Advisory Jurisdiction of the International Court and the Settlement of Disputes between States', International and Comparative Law Quarterly, 15 (1966), p. 325.

${ }_{17}$ Western Sahrara case, ICY Reports, 1975, p. 12. Cf. Eastem Carelia case, PCIY, Series B, No. 5 (1923), where it was stated that "no State can, without its consent, be compelled to submit its disputes with other States either to mediation or to arbitration, or to any other kind of pacific settlement': p. 27.

א* ILO Administratice Tribunal case, ICy Reports, 1956, pp. 83-4; Fitzmaurice, loc. cit. above (n. 55), p. 139. See also Fitzmaurice, "The Law and Practice of the International Court of Justice: International Organizations and 'I'ribunals', this Year Book, 29 (1952), p. I, at pp. 45-55.

*. Interlocutory Decision, loc. cit. above (n. 6), p. 1521 . 
dispute ${ }^{\circ}$ ), and that the FRY had certainly not explicitly consented to its competence on the point. As suggested above, however, the Commission did appear to consider that some form of consent could be imputed to the FRY in virtue of its participation in the activities of the Commission at an earlier stage. One may recall in this regard that a significant consideration in the Eastern Carelia case had been the fact that Russia was not a Member of the League of Nations nor a party to the Statute of the Permanent Court. As far as the ICJ was concerned, this was a major point of distinction, such that in the Western Sahara case it noted that 'Spain is a Member of the United Nations and has accepted the provisions of the Charter and Statute; it has thereby in general given its consent to the exercise by the Court of its advisory jurisdiction'.91 If there is sufficient basis for an analogy being drawn between the role of the ICJ and that of the Arbitration Commission (a point which is somewhat doubtful), it may be argued that the FRY's participation in the work of the Commission and the Conference can be assimilated to prior consent. ${ }^{92}$

With respect to the third point, the Commission noted that the Conference for Peace in Yugoslavia had a mission 'to reestablish peace for all in Yugoslavia and to achieve lasting solutions which respect all legitimate concerns and legitimate aspirations'. ${ }^{93}$ The Commission considered that in attempting to enlighten the Conference on the legal aspects of problems encountered it was acting entirely within the role entrusted to it by the EC, its Member States, and the six Republics. It might be questioned, however, whether the Arbitration Commission had really done enough to establish the institutional interest in the case at hand. Certainly, Serbia had participated in the Conference on Yugoslavia and had accepted the creation of the Arbitration Commission, but whether that participation is sufficient to establish a legitimate interest on the part of the Conference in the status of the FRY under international law is open to question. Further, it is doubtful whether a strict analogy can be drawn with the position of the ICJ as the principal judicial organ of the UN, in so far as the role of the ICJ is set out in the UN Charter, which is ratified by Member States, and which defines in concrete terms the purposes of the organization itself. These matters come into focus in

The Eastern Carelia case has been distinguished on a number of occasions on the basis that the question to be addressed did not address the merits of the dispute: see Peace Treaties case, ICJ Reports, 1950, p. 65, at p. 70; Interpretation of Article 3, Paragraph 2, of the Treaty of Lausanne case, PCIf, Series B, No. 12.

9' Western Sahara case, ICY Reports, 1975, p. 12. That Spain was only said to have given its consent 'in general' may suggest that in certain circumstances consent may not be imputed from membership alone.

${ }_{92}$ Pomerance, op. cit. above (n. 83), p. 295. The fact that the PCIJ Statute was not organically linked to membership of the League of Nations is often cited as one of the reasons for the more tentative approach that was apparently adopted by the PCIJ: see Rosenne, op. cit. above (n. 55), pp. 60-70.

93 Ibid. 
the second challenge directed against the jurisdiction of the Arbitration Commission. ${ }^{9+}$

\subsection{The Second Challenge to furisdiction}

The FRY launched a second assault upon the jurisdiction of the Commission on 30 April 1993. On this occasion the challenge related to the Commission's competence to deliver opinions relating to the division of the assets and liabilities of the SFRY, and to deliver advisory opinions on the principles by which the succession of States to the SFRY would be effected." In doing so, the FRY made a number of inter-related points. First, it considered 'unacceptable' the idea that the Commission should discuss the principles upon which succession should be determined 'prior to any substantial discussion of these principles within the Succession Group of the Conference on Yugoslavia' '." Secondly, recalling its earlier challenge to the Commission, it argued that the Commission 'was not established or composed for arbitration purposes' and that its work within the Conference on Yugoslavia 'has been seriously in breach of both the law and procedure and implementation of material law'.97 Thirdly, it reiterated that all disputes arising as regards the division of assets and liabilities 'should be referred by agreement either to the Permanent Court of Arbitration ... or to an ad hoc arbitration court' ${ }^{9}$ In that regard it pointed out that it considered arbitration proceedings as being 'proceedings before a court of law in the sense of general international law and not as proceedings before the Arbitration Commission presided by Mr Badinter' "\% Finally, it was argued that the opinions of the Commission were 'doctrinary in the sense of article $38(\mathrm{~d})$ of the Statute of the International Court of Justice, which do not constitute a legal ground for any valid decision'. Accordingly, the FRY determined that it 'shall consider null and void and non-binding any

4+ The Commission did not comment on the final two points raised by Serbia and Montenegro, namely that the questions should be resolved by the parties concerned, and that outstanding disputes should be referred to the ICJ. It may be presumed that the Commission considered these issues not to be relevant given its assumption of competence in the matter at hand. It is worth noting, nevertheless, that the ICJ did not consider this statement sufficient to establish a prima facie basis for its jurisdiction in the Genocide casc: case concerning Application of the Convention on the Preqention and Punishment of the Crime of Cenocide, ICF Reports, 1993, p. 3. It was considered that the statement did not make clear whether it was intended as an immediate commitment to accept unconditionally the unilateral submission of a wide range of legal disputes; or as a commitment solely to submit the three questions raised by the Chairman of the Commission; or as 'no more than the enunciation of a general policy of favouring juidicial settlement': ibid., p. 18.

's Statement of 30 April 1993 by the Government of the Federal Republic of Yugoslavia, International Legal Materials, 32 (1993), p. 158 .

on Ibid.

97 Ibid.

on Ibid.

c) Ibid., p. I 582 . 
opinion of the Commission adopted in the procedure to which it has not agreed'. ${ }^{100}$

These objections were contained in a 'Statement' issued by the FRY issued to the Steering Committee of the Conference on Yugoslavia. While they were not directly addressed to the Commission itself (a fact that might be explained by the FRY's contention that the Commission did not have the power to determine its own jurisdiction ${ }^{101}$ ), the Arbitration Commission 'considered it an appropriate opportunity to set out the scope and limits of its competence'. Nevertheless, the document containing the Commission's response was not entitled, as in the earlier case, an 'interlocutory decision', but rather merely 'Reactions of the members of the Arbitration Commission'. ${ }^{102}$ Further, it was made clear that the document reflected the opinions of 'members of the Arbitration Commission' rather than of the Commission as a whole, and that it 'in no way prejudges ... the competence of the Commission in this matter if it is challenged on grounds which they deem justified'. ${ }^{103}$ In other words, the document was an informal response issued by the individual members acting ex officio and in a collective capacity, which did not in any way prejudice the ability of the Commission to address other matters that merited an official response. Why the Commission took the unusual step of issuing only an informal response is unclear. Although it had not been directly asked to respond to the statement issued by the FRY, it might have been appropriate for the Commission to have addressed the issues while acting proprio motu. ${ }^{104}$ Equally, the suggestion that it should only respond officially in cases where the challenge is 'justified' would appear to entail an unwarranted element of prejudgment.

By this stage, the constitution of the Arbitration Commission had been placed on a new footing. Its composition and terms of reference had been re-defined in a document dated 27 January 1993 issued by the Steering Committee of the Conference on Yugoslavia. ${ }^{105}$ Although the document did not provide any firmer legal foundation for the Arbitration Commission, it did specifically lay down the terms of the Commission's contentious and advisory jurisdiction, and altered its terms of member-

100 Ibid.

101 Above, nn. 56-8.

102 Reactions of the members of the Arbitration Commission, International Legal Materials, 32 (1993), p. 1582.

103 Ibid.

${ }^{10+}$ As Judge McNair noted, 'An International tribunal cannot regard a question of jurisdiction solely as a question inter partes. That aspect does not exhaust the matter. The Court itself, acting proprio motu, must be satisfied that any State which is brought before it by virtue of such a Declaration has consented to the jurisdiction': Anglo-Iranian Oil Co. case, judgment of 22 July 1952 , ICF Reports, 1952, p. 93, at p. 116 (separate opinion). See also Judge Cordova, dissenting opinion in ILO Administrative Tribunal case, ICf Reports, 1956, p. 163.

ios International Legal Materials, 32 (1993), p. 1573. 
ship. ${ }^{106}$ According to paragraph 3 of that document, the Commission is competent to:

(a) Decide, with binding force for the parties concerned, any dispute submitted to it by the parties thereto upon authorization by the Co-Chairmen of the Steering Committee of the Conference;

(b) Give its advice as to any legal question submitted to it by Co-Chairmen of the Steering Committee of the Conference. ${ }^{107}$

The Commission pointed out that the six questions relating to the principles of succession had been referred to it for the purpose of receiving an advisory opinion according to the terms of paragraph $3(b)$. The implications of this were twofold. First, the competence of the Commission as an advisory body stemmed 'not from the consent of the parties concerned but from the mere fact of referral to it by the Co-Chairmen of the Conference'. ${ }^{108}$ The opinions constituted the Commission's participation in the work of the Conference and therefore were to be given not to the States concerned but to the Co-Chairman in order to furnish them with the information needed to take decisions'. ${ }^{\circ}$ Secondly, the opinions were essentially advisory in nature and possessed, in the words of the ICJ, 'no binding force'. 10 However, they did constitute a 'subsidiary means for the determination of rules of law' according to the terms of Article 38, paragraph $\mathrm{I}(d)$, of the Statute of the ICJ. The Commission noted, in the manner of a parenthesis, that if the parties were not able to reach an agreement in their negotiations, it was open for them to refer the matter to the Arbitration Commission under paragraph $3(a)$ or to any other adjudicatory or arbitral body of their choice."

10t Ibid. Pursuant to Article 4 of the terms of reference, the Arbitration Commission adopted at set of Rules of Procedure, ibid., p. 1575. The Rules stipulate, inter alia, that the members of the Commission shall be 'completely' independent and impartial' (rule 1.1) and that they shall maintain 'absolute secrecy in respect of the proceedings of the Commission' (rule 1.4); that the permanent members shall elect one of their number to be Chairperson for a three-year term of office (rule 2.1.); that it should be supported by a Secretariat with the necessary staff (rule 3.1.); that the Commission should mect in Paris unless otherwise decided (rule 4.1); that proceedings shall be as informal as possible' (rule 5.1.) and should be confidential until the opinion has been disclosed (rule 5.4); that in advisory proceedings the proceedings should normally be exclusively in writing (rule 7.1 ) and that in exceptional circumstances the Commission may decide to hear representatives of the parties concerned or other persons (rule 7.4); that decisions and opinions shall be adopted by majority vote, abstentions not being permitted (rule 8.1 ) but that no record of the number of votes constituting the majority should be made (rule 8.3.1.); that decisions and opinions shall state the grounds on which they are given (rule 8.2) and that any member in the minority may attach to the decision a brief dissenting opinion (rule 8.3.2); that while decisions shall be addressed to the parties concerned (rule 8.4.2.), opinions shall be addressed to the Co-Chairmen of the Steering Committee of the Conference and shall not be made public except on authority of the Co-Chairmen (rule 8.4.2.).

107 lbid.

1ok Reactions, loc. cit. above (n. 102), p. 1583.

Ioq Ibid.

in Interpretation of Peace Treaties casc, ICY Reports, 1950, p. 65, at p. 7 I

$\therefore$ Reactions, loc. cit. above (n. 102), p. 1583 . 
Although considerable problems remained, the reactions of the Commission to these points were considerably clearer and less objectionable than those produced following the first challenge. Not only was its mandate much more precise, making clear that it had both a contentious and an advisory jurisdiction, but it did not confuse matters by characterizing its activities as essentially those of an arbitral body. A question that might be raised, however, is whether the FRY could be deemed to have tacitly accepted the consultative jurisdiction of the Arbitration Commission as established in January 1993 in virtue of its participation in the work of the Conference on Yugoslavia. Although the Commission had been reconstituted, it was still only a creation of the Conference and lacked any treaty basis. At the same time it is difficult to argue, given the fact that the Commission was officially reconstituted in I 993 with a new mandate and a different composition, that the Republic's initial approval of the work of the Conference and its organs still had any significance. Indeed, since June 1992, the FRY had consistently opposed the work of the Arbitration Commission and therefore, as at April 1993, it could be assimilated to a third party, or a non-consenting member of the organization. If that is the case, it is arguable that its position was analogous to that of Russia in the Eastern Carelia case. In that case the PCIJ considered that, owing to the fact that the dispute involved a nonMember of the League, the exercise its advisory jurisdiction 'could take place only by virtue of their [Russia's] consent'. ' 2

Although the ICJ has not followed the practice of the PCIJ as regards the exercise of its advisory jurisdiction, a number of considerations point towards taking a somewhat stricter line on the question of consent in the context of the Conference than that adopted by the ICJ. Whereas the UN exists under a constituent treaty defining its objects and purposes and enjoys a 'large measure of international personality', "3 the same cannot be said of the Conference for Peace in Yugoslavia. It has no constituent instrument, possesses only an ill-defined set of 'organs', ${ }^{14}$ and does not prescribe the rights and obligations of the participating States. It is one thing for States to accept, by treaty, limitations on their sovereignty through membership in an organization where the purposes and powers of the organization are clearly set out," ${ }^{\text {s }}$ and where the rights and

\footnotetext{
" Eastern Carelia case, PCIJ, Series B, . No. 5 (1923), p. 27. Cf. Western Sahara case, ICJ Reports, 1975, p. 12, para. 30 .

13 Reparation for Injuries Suffered in the Sercice of the United Nations case, ICY Reports, 1949, p. 174 .

14 The only 'organs' as such that might be associated with the Conference are the Secretariat, the four Working Groups (Succession Issues; Institutions; Minorities Rights; and Economic Relations), the Arbitration Commission, and the Steering Committee.

is Lauterpacht could see no 'reason why the sovereignty of States should be protected from a procedure to which they have consented in advance as members of the United Nations, of ascertaining the law through a pronouncement which, notwithstanding its authority, is not binding on them': Lauterpacht, op. cit, above (n. 75), pp. 357-8. Fitzmaurice points out, however, that the consent is in itself only to a permissive jurisdiction, loc. cit. above (n. 55), pp. 142-3.
} 
obligations of the States vis à vis the organization are defined in advance. It is quite another for such limitations to be imputed to a State in virtue of its 'participation' in an organization with an ill-defined and openended mandate.

This argument is not displaced by the fact that the opinions of the Arbitration Commission are not binding. As the Commission noted itself, its opinions can nevertheless be treated as an authoritative statement of the law and would thereby be likely to affect the interests of the parties concerned when, and if, they came to negotiate on the matter. ${ }^{116}$ This point was not lost on the FRY, which later declared its intention of discontinuing its participation in the Working Group on Succession Issues, ostensibly because: '[i]n practice the opinions of the Commission, as an advisory body of the International Conference on the Former Yugoslavia, on the basis of which the Yugoslav participants at the Conference were to adopt relevant decisions by consensus taking also into account the Commission's opinion, were taken as judgements and served as a basis for making concrete decisions on relevant issues concerning the Yugoslav crisis'." The FRY evidently objected to the activities of a 'quasi-judicial' organ exercising jurisdiction over matters subject to dispute without its consent, and on the basis that there was some organizational interest on the part of the Conference.

\section{The Opinions of The Commission}

The Arbitration Commission issued a total of fifteen 'opinions' in its consultative capacity dealing with a range of issues including questions of statehood, recognition, self-determination and succession. It is not intended to consider in detail the opinions delivered to the EC Council of Ministers relating to the application of the Community Guidelines on Recognition (Opinions 4-7). ${ }^{1 / 8}$ In those opinions, the Commission did not attempt to interpret or apply general principles of international law, but rather acted as a fact-finding body in assessing whether the various Republics had fulfilled the criteria for recognition laid down in the Guidelines. As such, they are of less interest than the other opinions in

\footnotetext{
116 On the status of advisory opinions of the ICJ, see Pratap, op. cit. above (n. 55), pp. 227-34; Rosenne, op. cit. above (n. 55), pp. 744-7; Greig, loc. cit. above (n. 86), pp. 360-5; Hambro, 'The Authority of the Advisory Opinions of the International Court of Justice', International and Comparative Law Quarterly, 3 (1954), p. 2.

'17 Letter of 2 July 1993. International Legal Materials, 32 (1993), p. 1584.

' See generally Warbrick, 'Recognition of States: Part 2', International and Comparatize Law Quarterly, 4z (1993), p. 433; Rich, 'Recognition of States: The Collapse of Yugoslavia and the Soviet Union', European Yournal of International Law, 4 ( 1993 ), p. 36; Weller. 'The International Response wo the Dissolution of the Socialist Federal Republic of Yugoslavia', American fournal of International Law, 86 (1992), p. 569 .
} 
which the Arbitration Commission offered its own interpretation of international law in the context of the dismemberment of the SFRY. Rather than follow the pattern of the opinions entirely in sequence, it is intended to address the issues that arise under three general headings: statehood (secession/dismemberment), self-determination, and succession.

\subsection{Statehood (Secession/Dismemberment)}

The first question addressed by the Arbitration Commission arose from a difference in opinion between the Republics as to the legal nature of the crisis within the SFRY. On the one hand, Serbia contended that the Republics which had proclaimed, or intended to proclaim, independence were in fact seeking to secede from the SFRY, whose international personality would nevertheless continue. " 9 The other Republics (Croatia, Slovenia, Macedonia and Bosnia-Herzegovina) considered that there was 'no question of secession', but rather one of the 'disintegration or breaking-up of the SFRY as the result of the concurring will of a number of Republics'. ${ }^{20}$ Accordingly the personality of the SFRY would be extinguished and the six Republics would be considered equal successors in title.

The position adopted by the Arbitration Commission to this first question was significant in so far as it formed the basic framework for the later opinions. Although the question was formulated in terms of the identity and continuity of the SFRY, its significance essentially lay in the field of State succession. Traditional doctrine in the law of succession has tended to differentiate between cases of 'total' and 'partial' succession. ${ }^{121}$ If the Republics were to be seen as seceding from the Federation, the personality of the Federation would remain intact and it would continue to remain bound by existing international obligations and would retain its membership in international organizations. ${ }^{122}$ If, on the other hand, the new Republics emerged as a result of the general disintegration, or dismemberment ${ }^{123}$ of the SFRY, succession would be 'total' in the sense that each of the Republics would be an equal successor in title. While this does not necessarily entail that there would be a corresponding total or partial succession to the legal relations of the previous sovereign, ${ }^{124}$ the

"Opinion No. 1, loc. cit. above (n. 5), p. 1494.

120 Ibid.

'31 See O'Connell, State Succession in Municipal Law and International Law (1967), vol. 1, Pp. 3-4; Jennings and Watts, Oppenhein's International Law, vol. I (gth edn., 1992), pp. 208-9.

132 Below, n. 239.

123. The term 'disintegration' was used by the Chairman of the Peace Conference in the first question addressed to the Arbitration Commission, to describe the breaking-up of the SFRY. By contrast, the Commission used the term 'dismemberment'. Although the latter term appears to have more 'active' connotations, it is clear that neither is a legal term of art, and that both describe the same process.

i24 O'Connell, op. cit. above (n. I2I), p. 4. 
evidence points towards a greater degree of succession in cases of dismemberment than in cases of revolutionary secession. ${ }^{25}$ Indeed in cases of dismemberment there would, by necessity, have to be a reapportionment of the assets and liabilities of the parent State. ${ }^{126}$ Thus issues of succession were inevitably predicated upon an understanding as to the issue of continuity or otherwise of the State. Before turning to the question of personality, however, it is worthwhile briefly considering the interrelationship between principles of continuity and succession.

\subsubsection{Succession and identity/continuity}

The traditional distinction between the identity or continuity of the State, and State succession, is both artificial, ${ }^{127}$ and marked by confused terminology. ${ }^{28}$ The issue arose historically with the abstraction of the concept of sovereignty in the eighteenth and nineteenth centuries when a distinction came to be drawn between the legal consequences that attach to changes in government on the one hand, and changes in sovereignty on the other. ${ }^{29}$ It has become clear, however, that the notion of statehood itself is not sufficiently precise as to determine clearly in all cases where a change in the condition of a State has occurred, whether or not the personality of the State is affected (i.e. whether or not it 'continues'). Difficulties have arisen, for example, in distinguishing between cases of lawful annexation or union, ${ }^{30}$ and between cases of

12s With respect to conventional obligations, a number of cases point to the application of the clean slate doctrine in cases of revolutionary secession: e.g., secession of the Spanish American Colonies; secession of Texas, 1840 ; secession of Cuba, 1898 ; secession of Finland, 1919. See generally $O^{\prime}$ Connell, State Succession in Municipal Law and International Law (1967), vol. 2, pp. 88-100.

126 This is particularly the case with respect to immovable property located in the territory of third States: see Article $18(1)(b)$, Vienna Convention on Succession of States in Respect of State Property, Archives and Debts 1983, International Legal Materials, 22 (1983), p. 306.

i27 See e.g., Brownlie, op. cit. above, (n. 38). He comments: 'Unfortunately the gencral categories of "continuity" and "state succession", and the assumption of a neat distinction between them, only make a difficult subject more confused by masking the variations of circumstance and the complexities of the legal problems which arise in practice. "Succession" and "continuity" are levels of abstraction unfitted to dealing with specific issues': pp. 82-3.

'2K 'Continuity' as a term has been used both with respect to the personality of a State and as regards the rights and obligations assumed by successor States. See, e.g., O'Connell, op. cit. above (n. 121 ), pp. 9-25. This assimilation, however, was central to his thesis that the boundary between change of sovereignty and change of government in terms of their legal consequences should be reassessed: ibid., p. 6. Similarly, the term 'succession' is not infrequently used in reference to territorial entities which retain the personality of the parent State in the face of dramatic changes in its condition, e.g., announcement of Finland in relation to Russia, 30 December 1991, cited in Broms, 'The Agreement on the Foundations of Relations between the Republic of Finland and the Russian Federation', Finnish Yearbook of International Law, 3 (1992), p. 615, at p. 620.

r*4 $O^{\prime}$ Connell, op. cit. above (n. 1 21), p. 5. For an early view that admitted no such distinction, see Grotius, De jure belli et pacis (1625), book I1, xiv, p. I ; Vattel, Le Droit des gens (1758), book II, xii, p. I91. For the modern view, see Wright, "The Status of Germany and the Peace Proclamation', American Journal of International Law, 46 (1952), p. 299, at p. 307; Craw ford, op. cit. above (n. 47), pp. $28-9$.

1.30 e.g. unification of Italy, $1848-1870$. 
secession or dismemberment. ${ }^{31}$ In each category, the factual circumstances may well be similar, the conclusion as to continuity being derived from extraneous elements of procedure or assertion. The view that the unification of Italy, for example, came about through a process of annexation by the Kingdom of Sardinia in the period $1848-70$, rather than through a union of independent States, appears to be more a matter of perception and emphasis than one of fact. ${ }^{132}$ Similarly, on the facts alone, the break-up of Austria-Hungary can equally plausibly be argued either as a case of dismemberment involving the extinction of the personalities of Austria and Hungary, or as a case of the dissolution of the union and the corresponding secession of several national groups. ${ }^{13}$ Ultimately, while the facts upon which statehood is premised are always relevant, they are not necessarily sufficient as the sole determining considerations of continuity.

In most cases, questions of personality and succession go hand in hand and for that reason tend to become entangled. It is undoubtedly the case that the characterization of a particular situation as one of continuity or discontinuity will be heavily influenced by the respective claims made by interested parties. These claims themselves will necessarily reflect the interests of the States concerned as regards questions of succession. For example, in the case of Austria in 1919 , the difference in opinion arose primarily in relation to the issue of reparations; Austria denied continuity in order to avoid liability for reparations; the Allies, by contrast, wanted to establish continuity for converse reasons. ${ }^{3+}$ Similarly, the contention advanced by the USSR in 1919 that it did not represent the continuation of the Russian State may be attributed, in part at least, to the desire to avoid liability for the debts of its Tsarist predecessor. ${ }^{35}$

Whatever their interrelationship in practice there are, however, several reasons for clearly maintaining the distinction between identity and succession. First, on an abstract level, issues of identity and succession should be distinguished in so far as the former relate to the existence and identification of the legal subject, and the latter to the rights and duties that are to be assumed by a legal subject once it comes into existence or

\footnotetext{
131 e.g. dismemberment of Austria, 1918; secession of Pakistan, 1947; dismemberment of Mali Federation, 1959; dismemberment of United Arab Republic, 1961.

132 Anzilotti argued in favour of Union: Rivista di diritto internazionale, 6 (1912); see also Costa v. Military Service Commission of Genoa (1939), Annual Digest, vol. 9, No. 13. For the view that it was a case of annexation, see Marek, Identity and Continuity of States in Public International Law (1954), pp. 191-8.

133 See generally Feilchenfeld, Public Debt and State Succession (1931), pp, 431-755; Udina, L'estinzione dell'imperio Austro-Ungarico nel diritto internazionale (1933); Borchard, 'Sequestered Private Property and American Claims-The Treaties of Versailles and Berlin', American Yournal of International Law, 19 (1925), pp. 358-9; Anzilotti, loc. cit. above (n. 132), p. 86; Marek, op. cit. above (n. 132), pp. 199-236.

134 See generally Marek, op. cit. above (n. 132), pp. 199-236.

1.35 See, Oppenheim, op. cit. above (n. 121), p. 205.
} 
when it takes over responsibility for a new piece of territory. ${ }^{36}$ As such, the problem of State succession only arises once a conclusion is reached as to the issue of State personality. ${ }^{137}$ Secondly, it can be seen that problems of succession and personality do not always coincide. For example, if island State A were to lose permanently the entirety of its territory as a result of some natural occurrence (such as a rise in the sea level), the only question involved would be that of personality; the issue of succession would simply not be relevant. ${ }^{138}$ Finally, it has to be admitted that whatever arguments might be put forward for eliminating the distinction between continuity and succession (or between 'succession of States' and 'succession of governments'), 139 as long as the law of succession is premised upon the distinction, it will have to be maintained. ${ }^{10}$

\subsubsection{The dismemberment of the SFRY}

On 8 October 1991, when the suspension of their declarations of independence came to an end, Croatia and Slovenia purported to secede from the Federation.' ${ }^{+1}$ The question facing the Arbitration Commission, however, was whether the various acts of independence had, when

136 As Marek comments, "[w]hereas the problem of State identity and continuity bears on the identity of the subject. . . the problem of succession relates to the identity of certain rights and obligations between different subjects': op. cit. above (n. 132), p. 10 (original emphasis). Article 2 of the Vienna Conventions on the Succession of States 1978 and 1983 defines succession as 'the replacement of one State by another in the responsibility for the international relations of territory". It notably assumes that the question of personality has already been determined. See Craw ford, "The Contribution of Professor D.P. O'Connell to the Discipline of International Law', this Year Book, 51 (1980), p. 2, at p. 32.

1.37 Hall, International Law (8th edn., 1924), p. I1 4 ; Crawford, op. cit. above (n. 47), p. 29.

${ }^{13 *}$ No doubt significant legal problems might arise from such an occurrence (e.g. in relation to the disposal of debts, the rights of former nationals in third States, and any interest in property held on the territory of third States). But these problems would not be resolved by reference to principles of succession.

${ }^{314} \mathrm{O}^{\prime}$ Connell advocated a return to the 18 th century position (in which no distinction was made between succession of States or governments) overtly in order to ensure greater certainty (and arguably greater continuity) and suggested that the touchstone should be the degree of political, economic and social disruption: op. cit. above ( $\mathrm{n} .121), \mathrm{p} .25$. Cf. O'Connell, 'Independence and Problems of State Succession', in O'Brien (ed.), The New Nation in International Law and Diplomacy' ( 1965$)$, p. 7 , at p. I 1 .

140 See Crawford, op. cit. above (n. 47), pp. 29-30; Marek, op. cit. above (n. 132), pp. 9-13.

1+' Croatia and Slovenia initially declared their independence on 25 June 1991 (Keesing's, vol. 38 , p. $38274(199 \mathrm{I})$ ). In its 'Declaration of Independence' Slovenia declared that '[o]n the basis of the right of the Slovene nation to self-determination . . . the people of the Republic of Slovenia have decided to establish an independent State, the Republic of Slovenia, which will no longer be part of the Socialist Federal Republic of Yugoslavia': Blaustein and Flanz (eds.), Constitutions of the Countries of the World, Release 92-6, p. 55.

Croatia issued both a 'Declaration on the Establishment of the Sovereign and Independent Republic of Croatia' and a 'Constitutional Decision on the Sovereignty and Independence of the Republic of Croatia'. In the latter it was declared that, '[p]roceeding from the inalienable .. . right of the Croatian nation to self-determination, including the right of disassociation', Croatia was to establish herself as a 'sovereign and independent State'. Further, '[b]y this act Croatia initiates proceedings for disassociation from the other republics and from the SFRY': Blaustein and Glanz, ibid, Release 92-3, pp. $119,123$. 
taken in conjunction, affected the continuing sovereignty of the SFRY to the extent that it could be said to have become extinct as a legal person. Dismemberment, as a term descriptive of a set of circumstances in which a State has ceased to exist by virtue of the disassociation of its various territorial elements, stands alongside other 'categories' of extinction such as merger, ${ }^{1+2}$ absorption ${ }^{143}$ and (formerly) annexation. ${ }^{1+4}$ It is not a term of art, however, and is analytically useful only in so far as the range of situations it encompasses are analogous so as to form a coherent corpus of practice. In terms of actual (or posited) cases of dismemberment in the past century, most may be distinguished from that of the SFRY. A number of cases of dismemberment involved failed unions of preexisting States (such as the United Arab Republic $1960,{ }^{145}$ the Union between Norway and Sweden 1905, and possibly the Mali Federation $1960^{1+6}$ ) and for that reason, the problems of disassociation were considerably less acute. Others were accompanied by an agreement between the parties concerned (USSR I991, ${ }^{1+7}$ and Czechoslovakia $\left.1993^{148}\right)$, and have more in common with cases of devolution or cession than of dismemberment. The best analogy is that of Austria-Hungary in 1918 , but there the divergencies in views and practice as to the continuation or otherwise of Austria deprive it of much decisive value as a precedent. ${ }^{49}$

The approach adopted by the Arbitration Commission was on the face of it uncontroversial. As its starting point, it merely stated that 'the existence or disappearance of the State is a question of fact', ${ }^{\circ \circ}$ and in that respect the State is "commonly defined as a community which consists of a territory and a population subject to an organized political authority'

$1^{4 x}$ e.g. the union of Tanganyika and Zanzibar to create Tanzania in 1964. The union of Syria and Egypt to form the United Arab Republic was also intended to have extinguished the independent personalities of the two States (according to Arts. 1 and 58 of the Provisional Constitution of the UAR): see Cotran, 'Some Legal Aspects of the Formation of the United Arab Republic and the United Arab States', International and Comparative Lau Quarterly, 8 (1959), p. 346.

"4:" e.g. absorption of Congo Free State into Belgium in 1908; absorption of Montenegro into the Serb-Croat-Slovene State in 1919.

"4+ Acquisition of territory by conquest is no longer permissible under international law; see Oppenheim, op. cit. above (n. 121 ), p. 699. For a more circumspect approach, see O'Connell, Intermational Law (and edn., 1970), pp. 431-2.

¿5 See generally Cotran, loc. cit. above (n. 142); Young, 'The State of Syria: Old or New?', American Yournal of International Law, 56 (1962), p. 482 .

ith See generally Cohen, 'Legal Problems Arising from the Dissolution of the Mali Federation', this Year Book, 36 (1960), p. 375; Gandolfi, 'Naissance et mort sur le plan international d'un état éphémère: la Fédération du Mali', Annuaire francais de droit international, 6 (1960), p. 881; Shaw, Title to Territory in Africa (1986), pp, $213^{-4}$.

147 Agreement establishing the Commonwealth of Independent States, Alma Ata, 21 December 1991, International Legal Materials, 31 (1992), p. 138 . The USSR was technically not a case of dismemberment in that Russia was deemed to continue the personality of the USSR: see generally Mullerson, 'The Continuity and Succession of States by Reference to the Former USSR and Yugoslavia', International and Comparative Law Quarterly, 42 (1993), p. 473.

it See Malenovsky, Anmvaire francais de drait international, 39 (1993), p.305.

ito See Marek, op. cit. above (n. 132), p. 205.

150 Opinion No. I, loc. cit. above (n. 5), p. 1495. 
and which is 'characterized by sovereignty'. ${ }^{151}$ While the conditions outlined by the Arbitration Commission closely reflect the classical criteria for statehood, ${ }^{152}$ its approach could be subject to two qualifications. First, strictly speaking, a State is not a 'fact' in the same way as other material objects, but is rather a legal construction in which significance is attached to the existence of a certain state of affairs. ${ }^{153}$ The question is, therefore, a mixture of fact and law ${ }^{15+}$ and is one which may be subject to modification in virtue of the existence or emergence of other fundamental legal principles. ${ }^{155}$ Secondly, even if it is accepted that these factors generally govern the extinction as well as the creation of States, they assist little in determining the position in cases where the elements of Statehood are not extinguished in toto, but are rather merely altered or adjusted. In other words the real question is how far a State can survive fundamental changes to its condition even when it nominally continues to possess all the material elements of statehood.

Traditionally, scholars have sought to explain the 'continuity' of the State in face of changes in its condition, and have tended to ignore the more fundamental question of when the State itself may cease to exist. This, in part, has been moved by the perception that the existence of the State is a meta-legal phenomenon embracing historical and political facts which the law can only presuppose. ${ }^{16}$ Thus the notion of continuity has

is" Ibid.

isz Ibid. Clear reference is made in this regard to the Montevideo Convention on the Rights and Duties of States, 1933, League of Nations Treaty Series, vol. 165. p. I 9. Article I stipulates that "[ $t]$ he State as a person of international law should possess the following qualifications: $(a)$ a permanent population; (b) a defincd territory; (c) government; and $(d)$ capacity to enter into relations with other States'. Although the Convention refers to 'the capacity to enter into relations with other States', this has generally been treated as meaning 'independence': see, e.g., Harris, Cases and Materials on International Law (4th edn., 1991), p. 105, Crawford, op. cit. above (n. 47), pp. 47-8.

'Sovereignty' is more convincingly appreciated as a function of statehood and not a precondition: see Rousseau, Drott imternational public, w). 2 (1974), pp. 55-93; Craw ford, op. cit. above (n. 47), p. 71; Oppenheim, op. cit. above (n. 121), p. 122. As has been noted: 'sovereignty' in the relations between States signifies independence. Independence in regard to a portion of the globe is the right to exercise therein, to the exclusion of any other State, the function of a State': Island of Palmas arbitration, Reports of International Arbitral Auards, vol. 2, p. 829 , at p. 838 (per Huber). Cf. also Austro-German Customs Union case, advisory opinion, PCIY, Series A/B, No. 4 I (1931), per Judge Anzilotti.

is 3 That is not to say that the State is created by law. As . Warek notes: 'International law does not "create" States, just as State law does not "create" individuals. But it is international law and international law alone which provides the legal evaluation of the process, determines whether an entity is in fact a State, delimits its competences and decides when it ceases to exist': op. cit. above (n. I 32$)$, p. 2.

'st Waldock, 'General Course on Public International law', Receuil des cours, 106 (1 962-II), p. 5, at p. 146.

iss Crawford, op. cit. above (n. 47), p. +. One might note, in that respect, the prohibition of the use of force and the principle of self-determination which have been seen as operative principles in the acquisition of Statchood; below, nn. 183-4.

st" See e.g., Quadri, Diritta Internazionale Pubblico (1960). Charles de Visscher conceives of the factual basis of States as being distinct from the legal order. The historical facts which found the State are, in his words, 'des donées pré-juridiques'. He continues: 'L'ordre juridique international ne fond pas l'Etat; il présuppose son existence': Théories et réaltiés en droit international public (1970), pp. 184-5. 
been expressed in terms of the continuity of socio-political factors (such as population or territory) ${ }^{157}$ or the continuity of the national legal $\operatorname{order}^{158}$ (sometimes expressed in the form of sovereignty or its basic legal norm $\left.^{159}\right)$. While these considerations serve to construct the identity of States, in the sense of distinguishing between them, none of them sufficiently addresses the fundamental issue of a State's existence or its demise.

A good example of what might be termed the 'existence-identity paradox' is provided by the work of Marek. Marek appears to consider that in order to evaluate whether State $A_{1}$ is the same as or different from State $A$, which existed at an earlier time on the same territory, the central question is one of 'identity'. Rather than referring to the factual elements of statehood (which in an abstract sense all States by definition possess equally), she defines the identity of a State in terms of the identity of its rights and obligations. 'io Continuity, as such, is the 'dynamic predicate' '" $"$ ' of a State's identity and expresses its extension on the temporal plane. ${ }^{162}$ The answer, therefore, to whether there is continuity between State $A_{1}$ and State $A$ at different times, is determined by whether or not its rights and obligations remain relatively constant. There are two clear problems with this approach. First it introduces an unworkable level of relativism into the issue of identity ${ }^{163}$ in that it allows little scope for distinguishing between on the one hand, differences in the rights and duties of a State at two different points in time, and on the other hand, differences between two separate States. Secondly, as Crawford points out, it appears to suggest that the possession of rights and duties by an entity is a condition for statehood, rather than being an attribute of statehood. ${ }^{16+}$

What is interesting about the work of Marek, however, is that when she comes to determining the criterion by which the 'identity' of a State might be preserved, she returns to more familiar territory. Marek relies first upon the notion of independence, ${ }^{165}$ which she considers to be 'chiefly, but not exclusively, expressed in the delimination of the legal order of the State, that is, in its basic norm', ${ }^{166}$ and secondly upon the

157 e.g. Verdross, Völkerrecht (1950), p. 79.

15* Kelsen, Principles of International Law (2nd edn., 1966), p. 382.

1so Marek, op. cit. above (n. 132), p. 186.

so Ibid., p. 5 .

161 Ibid.

162 Cf. Kelsen, Principles of International Law (2nd edn., 1966), pp. 307-84. He remarks that '[a] State exists ... not only in space but also in time': pp. $381-2$.

16.3 Marek admits that '[a]ny definition of identity is, to some extent, relative': op. cit. above ( $n$. I 32), p. 5 .

16+ Crawford, op. cit. above (n. 47), pp. 401-2. It might be added, however, that this criticism assumes that Marek was actually concerned with the question of acquisition of statehood. It is arguable, in fact, that her test for identity was concerned with a different set of issues, namely, the distinguishing criteria of States.

16s Marek, op. cit. above (n. 132), p. 186.

1 to6 Ibid. 
extent of territorial and political changes. ${ }^{167}$ Ultimately, recognizing there to be a certain interdependence of principles, Marek argues that the extinction of a State only occurs when both the legal order and the territorial and personal delimitation of the State experience substantial changes. ${ }^{168}$

What this brief excursus indicates is two things. First, that far from being an issue of 'continuity' or 'identity' in the terms expressed, the issue is essentially one of the 'existence' or 'extinction' of the State. ${ }^{169}$ The identity of a State may be posited in a number of ways-according to its social, cultural, political, territorial or legal delimitation-but none of these expresses the terms by which the State is said to exist as a legal person. The rules for the existence of a State are external, abstract, rules and do not stipulate the need for a particular form of government, possession of a particular piece of territory or control over a particular section of the population. In other words, the notion of identity thus constructed is by definition too particularized for it to be determinative of a State's existence. Secondly, as the specific rules developed in Marek's work indicate, there is in fact less disagreement as regards the basic criteria by which the extinction of the State is to be determined than might at first be imagined: however posited, they appear to be little more than subtle applications of the basic requirements of statehood (territory, population, government and independence).

To conclude, it is clear that the factual predicates for a State's existence only provide broad parameters by which the existence of a State may be determined. For example, mere loss of territory (even if quite extensive) ${ }^{170}$ will not affect the legal personality of the State, ${ }^{17}$ nor will a political transformation in the State. ${ }^{72}$ Indeed, it has been accepted that in the context of belligerent occupation, complete lack of government does not extinguish the sovereignty of the State. ${ }^{173}$ While

\footnotetext{
is7 Marek argues that international law provides for the identity and continuity of a State in case of revolution on condition that the validity of the new revolutionary order corresponds more or less to the pre-revolutionary territorial and personal delimitation of that State': ibid., p. 63 .

its Ibid., p. 186.

ino Kunz, 'Identity of States under International Law', American Youmal of Intermational Law, 49 (1955), p. 68, at pp. $71-2$.

$17^{\circ}$ Guggenheim argues that the principle that territorial changes will not affect the identity of a State is subject to an exception where territorial change is 'quantitatively very considerable': Beiträge zur Völkerrechtlichen lehve vom Staatenwechsel (1925), p. 19. Hall similarly argues that territorial change must leave 'a part of the territory which can be recognized as an essential portion of the old State': $A$ Treatise on International Law (7th edn., 1917), p. 22. Kunz notes, however, that these are 'tautological statements, telling us that territorial changes do not affect the identity of the State, except when they do': The Changing Law of Nations (1964), p. 289.

i7' Turkey, for example, was considered the continuation of the Ottoman Empire, Ottoman Debt arbitration, Annual Digest, vol. 3, No. 57.

172 Protocol of London, 19 February 1831 , Martens, Nouveau recueil des traités, vol. 10, p. 197, at pp. 197-9. With respect to Russia, see Lazard Bros. \& Co. v. Midland Bank Ltd., Ammal Digest, vol. 6, No. 69.

17. Crawford, op. cit. above (n. 47), pp. 49, 418-19.
} 
this does not necessarily mean that 'there are no fixed criteria of State extinction', ${ }^{17+}$ it does suggest that a more synthetic approach is needed, taking into account both a combination of factual considerations and the assertions of all parties concerned, including those of other members of the international community (as might be expressed, for example, through the medium of diplomatic recognition).

As far as the Arbitration Commission was concerned, however, recognition had little formal significance: in its own words, 'the effects of recognition by other States are purely declaratory'. ${ }^{175}$ Without entering into the extensive and rather sterile debate over whether the function of diplomatic recognition is either declaratory or constitutive, ${ }^{176}$ it could be said that such a categorical position appears overstated. To say that recognition is 'purely' declaratory is to admit rather too easily the idea that the existence of international law is somehow independent of the appreciation of individual States. This is not to say that diplomatic recognition is therefore 'constitutive' in the sense that recognition becomes a sine qua non for the existence of international rights and duties, but rather that States have an active role in the construction, application and appreciation of norms of international law. ${ }^{177}$ For example, where there is some doubt as to the identity of a State, the position adopted by other members of the international community is highly significant. ${ }^{78}$

The Arbitration Commission subsequently qualified its rather dogmatic stance in respect of recognition in its later opinions. First, in

174 Marek op. cit. above (n. 132), p. 9.

175. Opinion No. 1, loc. cit. above (n. 5), p. 1495.

'7" See generally, H. Lauterpacht, Recognition in International Lav (1947); Dugard, Recognition and the United Nations (1987); Chen, The International Law of Recognition (1951); Oppenheim, op. cit. above (n. 121), pp. 126-203; Crawford, op. cit. above (n. 47), pp. 10-25; O'Connell, op. cit. above (n. 144), pp. 127-65; Brownlie, op. cit. above (n. 38), pp. 87-106. For support for the 'declaratory' view of recognition, see Deutsche Continental Gas-Gesellschaft v. Polish State (1929), Ammal Digest, vol. 5, No. 5; Tinoco arbitration (1923), Reports of International A rbitral Awards, vol. I, p. 369 (as regards recognition of governments). The principal problems with the constitutive theory of recognition are: (i) that it may lead to 'degrees of legal personality' according to how many States have recognized an entity; (ii) that unrecognized entities will not be burdened by any duties under international law; (iii) that it does not conceive of the possibility of illegal recognition. See Brierly, The Law of Nations (6th edn., 1963), pp. 138-40; Crawford, op. cit. above (n. 47), pp. I 8-20.

177 As has been noted, an act of recognition is more than mercly one of cognition, or knowledge that an entity possesses the factual elements of statehood. Recognition indicates, in addition, a willingness to bring about the legal consequences of that acknowledgement. See O'Connell, op. cit. above (n. 144), p. 128. Cf. Alexandrowicz, "The Quasi Judicial Function in Recognition of States and Governments", American Yournal of Intemational Law, 42 (1952), p. 631. Statehood may thus be said to be opposable as regards the recognizing State: Charpentier, La Reconnaissance intermationale et l'ézolution du droit des gens (1956), pp. $217^{-25}$.

${ }^{i k}$ Brierly comments that the primary function of recognition is to acknowledge as a fact something which has hitherto been uncertain, namely the independence of the body claiming to be a state, and to declare the recognizing state's readiness to accept the normal consequences of that fact, namely the usual courtesies of international intercourse': op. cit. above (n. 776 ), p. 139. 
Opinion No. 8, it noted that 'while recognition of a state by other states has only declaratory value, such recognition, along with membership of international organizations, bears witness to these states' conviction that the political entity so recognized is a reality and confers on it certain rights and obligations under international law'. ${ }^{179}$ Secondly, and more controversially, in Opinion No. 10 it asserted that "while recognition is not a prerequisite for the foundation of a state and is purely declaratory in its impact, it is nonetheless a discretionary act that other states may perform when they choose and in a manner of their own choosing, subject only to compliance with the imperatives of general international law, and particularly those prohibiting the use of force in dealings with other states or guaranteeing the rights of ethnic, religious or linguistic minorities'. ' 80 It is generally accepted that the formal act of 'recognition' is a discretionary one, and that there is no duty to accord recognition to a State even if it happens to fulfil the requisite criteria. ${ }^{2}{ }^{\prime}$ There is also some practice to suggest that there is a general duty of non-recognition ${ }^{1 / 2}$ where the emergence of a State is associated with some illegality, such as the prohibition on the use of force, ${ }^{1{ }^{*}}$ or a violation of the right of selfdetermination. ${ }^{8+}$ It is highly unusual, however, for it to be suggested

70 Opinion No. 8, loc. cit, above (n. 5), p. 1523.

iso Opinion No. 10, ibid., p. 1526.

14. The US Government has taken the position that "[i]nternational law does not require a state to recognize another entity as a siate, it is a matter of judgment of each state whether an entity merits recognition as a state': US Digest, $1976, \mathrm{p} .19$. This statcment is to some extent a response to the position espoused by both Lauterpacht and Chen that there is an international legal obligation on the part of States to recognize entities as States when they have fulfilled the necessary criteria: Lauterpacht, op. cit. above (n. 376), p. 61; Chen, op. cit. above (n. 176), pp. 50-4.

$1 *_{2}$ In analysing early State practice, $O$ ' Connell was sceptical about the existence of a 'custom of non-recognition': op. cit. above (n. 144), p. 147. Oppenheim notes, however, that a gradual change in attitude may be discerned: op. cit. above (n. 121), p. 185 . Although in practice duties of nonrecognition have mainly been identified in cases where the Security Council has so ordered (e.g. Southern Rhodesia, Namibia), it is considered that the duty exists independently of Security Council action. For the view that an obligation not to recognize a situation created by the unlaw ful use of force is 'self-executory', see Skubiszewski (dissenting opinion), casc concerning East Timor (Portugal v. Australia), judgment of 30 June 1995, paras. 125, $129-30$.

It should be noted, however, that this duty is arguably an imperfect one: recognition of an illegal situation is not necessarily forbidden by international law as States may well choose to waive the interest they have in the observance of the rule in question in order to give recognition to the factual existence of the entity. Indeed over time, such a choice may become inevitable: ex factis jus oritur, e.g. recognition of Ethiopia; Australian recognition of Indonesian rontrol of East Timor, case concerning East Timor, ibid., para. 17. That a State is ultimately recognized, however, does not serve to remedy the earlier illegality, but rather aftirms, in spite of it, the fact of effective government: Lauterpacht, op. cit. above (n. 1 76), p. 412; Crawford, op. cit. above (n. 47), pp. I21-3.

${ }^{1} H_{3}$ The cases of Northern Cyprus (1974-) and Manchukuo (1932-45) support the view that States will not recognize entities created following the illegal use of force. See Lauterpacht, op. cit. above (n. 176), p. 420 .

$1^{1 x^{+}}$e.g., Southern Rhodesia in $196_{5}$, when the Security Council adopted a resolution calling on all States 'not to recognize this illegal racist minority regime': SC Resn. 2 i 6 ( 12 November I965). The: Security Council later repeated this demand and went on to declare the declaration of independence as having no legal validity: SC Resn. 217 (22 November 1965). See generally Fawcett, 'Security 
that a putative breach of the rights of minorities should also prohibit recognition. The Commission's approach on this point is undoubtedly related to its view that the rights of ethnic, religious or linguistic minorities have the status of norms of jus cogens. If so, the Commission would also appear to suggest that norms of jus cogens apply to the question of statehood. This matter will be discussed in more detail below. ${ }^{185}$

These points aside, it is perhaps relevant to point out that recognition has only an indirect role in the extinction of States. States will not necessarily withdraw recognition from a State on its demise; ${ }^{46}$ more often than not, the withdrawal of recognition will merely be implied by the recognition of the succeeding State(s). For example, the UK withdrew recognition from Abyssinia in 1939 , not explicitly, but implicitly by recognizing de jure its annexation by Italy. ${ }^{187}$ Such practice is inevitable given that States need to be assured that they will not legally put themselves at risk in the period between the demise of one State and the emergence of its successor. Even taking into account the broadly declaratory nature of recognition, what this suggests is that it is unrealistic to assert the demise of one State before its successors have been clearly identified.

The main element of the Commission's first opinion was the legal construction it placed upon the facts before it. It noted that although 'the form of internal political organization and the constitutional provisions are mere facts', they need to be taken into consideration 'in order to determine the Government's sway over the population and the territory'. ${ }^{88}$ Accordingly, it argued that in 'a federal-type State, which embraces communities that possess a degree of autonomy and, moreover, participate in the exercise of political power within the framework of

Council Resolutions on Rhodesia', this Year Book, 41 ( $1965-6$ ), p. 102. In 1970, the SecurityCouncil called upon Member States to 'take appropriate measures, at the national level, to ensure that any act performed by officials and institutions of the illegal regime in Southern Rhodesia shall not be accorded any recognition': SC Resn. 277 (18 March 1970). The Security Council also declared the independence of Transkei to be 'invalid' and called upon governments to 'deny any form of recognition to the so-called independent Transkei': GA Resn. $31 / 6 \mathrm{~A}$ (1976), endorsed in SC Resn. 402 (1976). These cases have been interpreted in two main ways: either as an affirmation that selfdetermination is an additional criterion for statehood (Crawford, op. cit. above (n. 47), pp. $8 \mathrm{r}$, 102-6); or as evidence of self-determination as a norm of $j u s$ cogens serving to vitiate an otherwise established case of statehood, (Dugard, op. cit. above (n. 176), p. 147). For a moderate position, see Greig. 'Recognition and the United Nations', Australian Yearbook of International Law, 12(1992), p. 296.

ins Below, nn. 283-97.

186 The Montevideo Convention of 1933 provides that 'Recognition is unconditional and irrevocable': loc. cit. above (n. 152), p. 19. Practice suggests, however, that recognition may be withdrawn upon a State's demise: see, e.g., US withdrawal of recognition from Montenegro, US Foreign Relations, t921, vol. 2, p. 946.

i" See Haile Selassie v. Cable and Wireless Ltd. (No. 2), [1939] Ch. 182. On the question of Abyssinia, see Marek, op. cit. above (n. 132), pp, 331-7. On current UK practice as regards recognition of governments, see Talmon, 'Recognition of Governments: An Analysis of the New British Policy and Practice', this Year Book, 63 (1992), p. 231, at p. 263.

${ }^{\mathrm{HB}}$ Opinion No. 1, loc. cit. above (n. 5), p. 1495. 
institutions common to the Federation, the existence of the State implies that the federal organs represent the components of the Federation and wield effective power'. ${ }^{89}$ Turning then to the position of Yugoslavia, the Commission noted that four of the six Republics had indicated their desire for independence, and that the 'composition and workings of the essential organs of the Federation' no longer met 'the criteria of participation and representatives [sic] inherent in a federal state'. 190 Consequently, it came to the conclusion that the SFRY was in the process of dissolution' 'o' and that therefore the Republics were to settle such problems of State succession as may arise in keeping with the principles and rules of international law, "with particular regard for human rights and the rights of peoples and minorities.' 192

As to the factual basis for the Commission's assessment, there is little with which to disagree. By the time of its decision, Slovenia and Croatia had both actively asserted their independence from the Federation, ${ }^{193}$ Macedonia had held a referendum on independence, ${ }^{194}$ and the Parliament of Bosnia-Herzegovina had adopted a resolution on sovereignty. The Republics of Slovenia, Croatia and Macedonia had also withdrawn their representatives from participation in the Presidency ${ }^{195}$ and other federal organs 106 following a dispute over the nomination of a representative for Kosovo, ${ }^{197}$ and the Serbian rejection of the incoming Croatian

ixo Ibid.

ise Ibid.

1\%. It was later made clear in Opinion No. 8 that this did not mean the immediate expiry of the personality of the SFRY'- the SFRY Was at that time still a legal international entity': Ioc. cit. above (n. 5), p. 1522 .

(1)2 Ibid.

143 Slovenia initially made moves towards autonomy in 1989 when it included in its constitution a provision declaring it to be 'an independent, sovereign and autonomous State': Keesing's, vol. 35, pp. 36899-36900 (1989). On 23 December 1990 it held a referendum in which $94.6 \%$ of votes were cast in favour of secession: Keesing's, vol. 36, p. 37790 (1990). Croatia held a referendum on independence on 19 May $199 \mathrm{r}$ in which $92.2 \%$ of voters fuvoured secession: Keesing's, vol. 37 , p. 38204 (1991). Both Croatia and Slovenia initially declared their independence on 25 Junc $199 \mathrm{r}$ : Keesing's, vol. 38, p. 38274 (1991). See above, n. 141. 'They subsequently agreed, in Brioni, to a three month moratorium on their independence: Keesing's, vol. 37, p. 38374 (1991). See generally Weller, loc. cit. above (n. I 3); Zametica, 'The Yugoslav Conflict', Adelpli Paper No. 270 (1992); 'Thompson, A Paper House: The Ending of Yugoslavia (1992); Glenny, The Fall of Yugoslavia (1993); Glenny, The Rebirth of History (2nd edn., 1993); Malcolm, Bosnia: A Short History (1994); Magas, The Destruction of Yugoslazia (1993); The United Nations and the Situation in the Fomer Yugoslazia (UN publication, 1995 ).

194 Keesing's, vol. 37, p. 38420 (1991).

175 The remaining Republics formed a 'Rump Presidency' which assumed the powers of the full Presidency, but without constitutional authority: Keesing's, vol. 37, p. 38513 (1991).

'uesing's, vol. 37, pp. 38420, 38559 (1991): Magas, op. cit. above (n. 193), p. 295 -

(97) In March 1991 the representative of Kosovo to the Presidency was replaced by an appointee of the Serbian Assembly (Bajramovic). Magas comments: 'Without a functioning assembly, Kosovo representatives in the Federal Assembly and on the Federal presidency became illegitimate, and with them also the work of these bodies': op. cit. above (ת. 193), pp. 291-2. 
President, Stipe Mesic. ${ }^{198}$ At the same time, although the Federal Presidency had initially sent federal troops into Slovenia, ${ }^{199}$ by September I99I it was clear that the federal organs no longer had direct control over the conflict. ${ }^{200}$ As the Commission itself noted, the authorities of the Federation and the Republics showed themselves to be 'powerless to enforce respect for the succeeding ceasefire agreements concluded under the auspices of the European Communities or the United Nations'.201

Even if the Commission's assessment of the facts is accurate, one may question the conclusions it draws from them. The first point is the emphasis it apparently placed upon the internal structure of the Federation as a basis for asserting the dismemberment of the Federation. As a general proposition, the criteria governing the legal existence of a State do not vary according to the type of political or social system that is operated. As the ICJ noted in the Western Sahara case, 'no rule of international law, in the view of the Court, requires the structure of the State to follow any particular pattern, as is evident from the diversity of the forms of State found in the world today'. ${ }^{202}$ Even if it is accepted that self-determination has become an additional criterion for statehood, ${ }^{203}$ requiring accordingly a certain level of representativity, as Crawford noted, ' $[t]$ his principle does not-at this stage of the development of international law and relations-constitute a principle of law with respect to existing States'. ${ }^{20+}$ Nevertheless, it appears that the Commission was not directly asserting that the criteria for statehood differed according to the internal structure of the State, but rather that the system

io* Keesing's, vol. 37, pp. 38203-4 (1991). The Federal Presidency had eight members, one from each of the six republics and the two autonomous provinces. Fach of the representatives was to be elected by secret ballot in the appropriate provincial assembly. The President was elected by the Presidency according to a strict rota each year. In 1989 the post was held by Slovenia (janez Drnovsek), in 1990 by Serbia (Borisav Jovic), and it was due to go to Croatia (Stipe Mesic) in 1991 . The constitutional deadlock continued until June 30 when Mesic was eventually proclaimed President: Keesing's, vol. 37, p. 38275 (1991).

11920esing's, vol. $3^{8}$, p. $3^{8275}$ (1991).

${ }_{200}$ On 12 September, the Defence Minister, Veljko Kadijevic, rejected an order to withdraw JNA troops to barracks. Mesic, in response, called upon JNA soldiers to desert: Keesing's, vol. 37, p. 38421 ( 1991 ).

tox Opinion No. 1, loc. cit. above (n. 5), p. 1497.

202 ICY Reports, 1975, p. 12, pp. 43-4.

20.3 Fawcett argues, in light of the Southern Rhodesia case, that to the traditional criteria for the recognition of a regime as a new State must now be added the requirement that it shall not be based upon a systematic denial in its territory of certain civil and political righes, including in particular the right of every citizen to participate in the government of his country, directly or through representatives elected by regular, equal and secret suffrage': op. cit. above (n. 184), p. I 12 . For a different view see Dugard, op, cit. above (n. 176), pp. 128-31; Devine, 'The Requirements of Statehood Re-examined', Modern Law Review, 34(197 r), p. 410.

${ }^{20}+$ Craw ford, op. cit. above (n. 47), p. 105. It is considered, however, that no distinction can be made between new and existing States. The personality of a State, premised by certain conditions of fact and law, is an enduring phenomenon and must be seen to be a test for the continued existence of States as much as their creation. Cf. Arbitrator Huber, Island of Palmas case (1928), Reports of Intermational Arbitral Awards, vol. 2, p. 829 . Accordingly, if self-determination is not an operative criterion as regards existing States, it cannot be so with respect to new States. 
of government had to be taken into account for the purposes of determining its effectiveness. While this may be presumptively more consistent, it still suggests that the test of effectiveness may differ according to the type of government established within a State.

The Arbitration Commission's appreciation that the effectiveness of a State is conditioned by a degree of participation and representativity may be considered too strict for normal unitary States. It is certainly true that the representatives of the organs of the State may well influence the credibility of a government's claim to wield effective authority over a portion of its territory in face of an act of secession, but it cannot be accepted that as a general proposition the personality of a State is extinguished merely by lack of representativity or participation in government itself. What needs to be distinguished is the notion of control on the one hand, which concerns the de facto authority exercised by the government over the people, and the notion of participation on the other, which serves as a legitimizing principle, but which traditionally has no significance with respect to a State's personality. Much as the EC Member States and other members of the international community conditioned their recognition policy upon a requirement of a referendum and the institution of minority guarantees, ${ }^{205}$ it has to be accepted from State practice that so long as a government continues to wield power over its territory, any lack of representativity will be of little consequence as far as its continuity is concerned.

Although international law does not formally recognize any distinction between unitary and federal States in terms of their personality, it may be argued that the test of effectiveness in the case of federal States is different. Federations have been thought to be characterized by a constitutionally guaranteed division of power between central and regional government in which both forms of government exercise, at the same time, independent and direct control over the population. ${ }^{20}$ Although it is the federal State that will generally have full (although not necessarily exclusive ${ }^{207}$ ) authority over foreign affairs, ${ }^{208}$ and will be considered the person in which the sovereignty of the State is vested in terms of international law, ${ }^{209}$ sovereignty, in terms of competence over functions of the State, is divided between the federal and constituent governments. Even if the variety of forms of federations and unions precludes the identification of universal principles, it might be argued

${ }^{205} \mathrm{EC}$ guidelines on recognition, Eturopean Journal of International Law, 4 (1993), p. 72.

zot Bernier, Intermational Aspects of Federalism (1 973), p. 5.

207 e.g. Byelorussia and Ukraine under the 1977 Constitution of the USSR. Article 80 provided that a Lnion Republic shall have the right to enter into relations with foreign States, conclude treaties with them and exchange diplomatic and consular representatives, and participate in the work of international organizations'. See generally Dobrin, Transactions of the Grotius Society, 30 (19+4). pp. $260-83$.

${ }_{20 \mathrm{~N}}$ See Stoke, The Foreign Relations of the Federal State (1931).

204 Montevideo Convention, 1933. Art. 2, League of Nations Treaty Series, vol. 165, p. 19. 
that in cases such as that of Yugoslavia where the constituent Republics possess a high degree of autonomy, ${ }^{210}$ the only real test of effectiveness for the federal government is the extent to which the constituent entities participate in its organs. It is considered, however, that even in these circumstances the test appears too rigid and inflexible. Effectiveness should not be calculated in a mathematical fashion merely by reference to the number of constituent Republics that continue to participate in the federation. Rather, it should be determined by effectiveness on the ground, namely by reference to population and territory over which the government continues to hold sway. This may not render a radically different conclusion to the case in hand, but it avoids the conclusion that federal States, in virtue of their devolved systems of government, are necessarily more fragileas legal persons.

Even if it is accepted, considering the matter purely as one of control, that the federal government could not be said to be effectively 'governing' the territories in question, whether or not this is sufficient to conclude that the SFRY was in the process of dismemberment, and one might presume extinction, appears somewhat doubtful. Prior to these events, there was much concurrence in the view that a strong presumption existed in favour of the continuity of an established State. ${ }^{21}$ Statehood would not be affected merely by a change in government or territory. ${ }^{212}$ Indeed, as Crawford notes, "[e]xtinction is thus, within broad limits, not affected by more or less prolonged anarchy within the State'. ${ }^{213}$ A case in point is that of Austria-Hungary where, despite the extensive territorial changes and the change in government, certain States persisted in the view that the personality of Austria continued intact. ${ }^{21}+$ Even if this was not a universally accepted view, it

210 The Federation of Yugoslavia consisted of six Federal Republics (Slovenia, Croatia, BosniaHerzegovina, Montenegro, Serbia and Macedonia) and two Autonomous Regions (Kosovo, Vojvodina). Each of the six Republics essentially represented the territorial 'home' of one of the Yugoslav nations (Serbs, Croats, Solvenes, Muslims, Macedonians and Montenegrins), although only Slovenia was ethnically homogenous ( $90 \%$ Slovene). The 'nations' of Yugoslavia were considered sovereign in that they were deemed to have entered into the federation through a process of 'free association', retaining a right to self-determination and secession: 1974 Yugoslav Constitution, Basic Principles 1(1). See generally Ramet, Nationalism and Federalism in Yugoslavia 1963-1983 (1984), pp. 20-84; Bagwell, 'Yugoslavian Constitutional Questions: Self-Determination and Secession of Member Republics', Georgia Yournal of International and Comparative Law, 21 (1991), p. 489. The Federation was highly decentralized, the constituent Republics enjoying complete freedom of economic management and a high degree of political autonomy: Lapenna, "Main Features of the Yugoslav Constitution 1946-197', International and Comparatize Law Quarterly, 2 I (1972), p. 209. In virtue of the constitutional amendments of 1969 the Republics were awarded the right to participate autonomously in the foreign policy of the Federation by directly engaging in contacts with foreign States: Ramet, op. cit. above, p. 8r .

21 Marek, op. cit, above (n. 132), p. 548; Crawford, op, cit, above (n. 47), p. 417.

112 Above, nn. 170-2.

213 Crawford, op. cit. above (n. 47), p. 417. Cf. Somalia, 1994.

2: This was the view taken by the Allies, support for which is found in the Treaty of St Germain, 1919. Austria lost nearly $75 \%$ of its pre-war territory and over $75 \%$ of its population: Marek, op. cit. above (n. 1 32), pp. 199-236. 
clearly points to the fact that the extinction of a State cannot be lightly presumed. Turning to the case of Yugoslavia then, even though four of the Republics had indicated their desire for greater independence, only Slovenia and Croatia had actually issued a declaration of independence by December 1991 and had taken steps to assert that independence. Macedonia had only held a referendum on the question, ${ }^{215}$ and BosniaHerzegovina had merely adopted a sovereignty resolution within its Parliament. In fact, neither of the latter States had entirely dismissed the possibility of continued participation in Yugoslavia within a loose union of sovereign States, ${ }^{216}$ and neither had at that stage secured their borders or required the removal of federal forces. ${ }^{217}$ Equally, although some of the Republics had withdrawn from participation in the organs of the Federation, the Federation continued to operate in the form of the Rump Presidency with two of the six Republics still participating in the Federation. This being the case, one might question whether the opinion of the Commission was not premature.

It is apparent that the Arbitration Commission appreciated the difficulty of merely declaring the dismemberment of the Federation, in that it attempted to mitigate the force of its statement by remarking that the Federation was 'in the process of' dismemberment. ${ }^{218}$ One might question, however, whether the idea of a 'process of dismemberment' has any legal meaning. Dismemberment, as was noted above, is merely descriptive of a form of extinction following the disassociation of various territorial units. As such, it can only really be attributed to a situation $e x$ post facto once the lack of continuity of the State has been finally determined. If the issue is simply whether or not a State continues to exist, it makes no sense to speak of dismemberment as a process. Indeed the Commission later made clear that, at the time of its first opinion (December 1991), the SFRY was 'still an international entity'. If that was the case, one can only understand the Commission's finding as a prediction about events of which it could only guess, and in which case it should properly have refrained from offering its opinion.

However premature the Commission's first opinion, subsequent evidence suggests that the dismemberment of the SFRY has since been effected. On 18 May 1992, the Chairman of the Conference for Peace in Yugoslavia, Lord Carrington, asked the Arbitration Commission inter alia whether the process of dissolution, to which it had previously

213 Above, n. 194.

$\therefore$ Keesing 's, vol. 37 , p. 38420 (1991). It would appear, nevertheless, that Macedonia and BosniaHerzcgovina were only willing to continue their association within Yugoslavia if both Croatia and Serbia were also involved. When it became clear that the international community would recognize Croatia as an independent State, their departure became inevitable.

${ }^{217}$ An agreement was erentually reached as to the withdrawal of forces from Macedonia by April 1992; Keesing's, vol. 38 , pp. 38779,38833 (1992).

${ }_{218}$ Opinion . vo. 1, loc. cit. above (n. 5), p. 1496. 
referred, could be regarded as complete. ${ }^{219}$ The Commission began by noting, rather belatedly it seems, that as 'the dissolution of a state means that it no longer has legal personality', and that it has 'major repercussions in international law', there was a need for 'the greatest caution'. 220 It went on to state that 'the existence of a federal state, which is made up of a number of separate entities, is seriously compromised when a majority of these entities, embracing a greater part of the territory and population, constitute themselves as sovereign states with the result that federal authority may no longer be effectively exercised'. ${ }^{221}$ Recalling, inter alia, ${ }^{222}$ the fact that 'the former national territory and population of the SFRY are now entirely under the sovereign authority of new states', and that 'the common federal bodies on which all the Yugoslav republics were represented no longer exist', the Commission concluded that 'the process of dissolution of the SFRY ... is now complete and that the SFRY no longer exists'. ${ }^{223}$

In coming to the conclusion that the SFRY was extinct as a State, the Commission made three important assertions: first, that a majority of the constituent entities of the Federation had sought independence from the Federation; secondly, that all the territory occupied by the SFRY was under the control of new sovereign States (ie. that all the Republics had acquired statehood); and thirdly that the newly formed FRY (Serbia and Montenegro) could not be considered the continuation of the SFRY.224 With respect to the first issue, it has already been noted that, according to general principles, the personality of the SFRY cannot be considered extinct merely by reference to the level of participation of the constituent Republics. ${ }^{225}$ In this later opinion, however, it is significant that the Commission also takes note of the fact that the Republics attempting to disassociate themselves constituted 'the greater part of the territory and population'. ${ }^{226}$ This observation is arguably crucial in the context of Yugoslavia in so far as it provides a partial basis for distinguishing between it and the case of the USSR, the personality of which was deemed to continue in the form of Russia. The Russian Republic's territory constituted $76 \%$ of the total territory of the USSR (22.4 million $\mathrm{km}^{2}$ ) and $5 \mathrm{r} \%$ of the total population ( 148 million). The territory of the FRY, by contrast, comprises $40 \%$ of the territory of the SFRY, and its population, $45 \%$ (10.5 million). Although it would be wrong to place too

a" Opinion No. 8, loc. cit. above (n. 5), p. I 519 .

220 lbid., p. 1522.

22, Opinion No. 8, loc. cit. above (n. 5), p. I522.

222 The Arbitration Commission first noted that a referendum held in Bosnia during February and March 1992 had found a large majority in favour of independence, and that Serbia and Montenegro had "constituted a new state, the "Federal Republic of Yugoslavia", and on 27 April adopted a new constitution': ibid., p. 1523.

22.3 Ibid., p. 1523 .

224 Ibid.

225 Above, nn. 202-10.

22t Opinion No. 8, loc. cit. above (n. 5), p. 1523 . 
much emphasis upon such considerations, they are significant when combined with other factors such as the reactions of other members of the international community (the concurrence of the other former Soviet States being highly determinative in the case of Russia).

As to the second question, the Commission noted that BosniaHerzegovina, Croatia and Slovenia had each been recognized by all the Member States of the EC and 'numerous other states', ${ }^{27}$ and had been admitted to membership of the UN. Lest it be argued that the diplomatic recognition of the various Republics does not conclusively demonstrate their statehood, the Commission noted that recognition, whilst being merely declaratory, 'bears witness to these States' conviction that the political entity so recognized is a reality and confers on it certain rights and obligations under international law' ${ }^{2{ }^{28}}$ What the Commission did not mention was the fact that neither the FRY nor the Republic of Macedonia had attracted diplomatic recognition by the time of its opinion. It may be excused, however, for considering such matters as irrelevant. ${ }^{229}$ 'The failure of the international community to recognize Macedonia was more out of deference to Greek sensibilities than any material factor that operated to disqualify Macedonia from acquiring statehood. ${ }^{230}$ At that time, Greece and Macedonia were in dispute over the latter's name which was said to be an appropriation of Greek heritage and a threat to the territorial integrity of Greece. ${ }^{23}$ ' As regards the FRY, in claiming to be the continuation of the former SFRY, it had not in fact sought international recognition at all. Indeed, when it came to consider the position of the FRY in its tenth opinion, the Arbitration Commission considered that 'within the frontiers constituted by the administrative boundaries of Montenegro and Serbia in the SFRY, the new entity meets the criteria of international public law for a State'. ${ }^{2.32}$

The third assumption upon which the Commission based its opinion was that the personality of the SFRY did not continue in the form of the

$2 x 7$ Ibid.

$22 k$ Ibid.

220 Macedonia was only recognized after its admission into the UN in April 1993 under the name 'the former Yugoslav Republic of Macedonia'; SC Resn. 817 (1993); Keesing's, vol. 39. pp. 39428, 39698,39785 (1993). The UK considered its support for the application for UN membership by the Republic as an act of recognition: see HC Debs., vol. 223, WA, col. 241, 22 April 1993.

2.10 The Arbitration Commission had previously opined that the Republic of Macedonia complied with the EC guidelines on recognition: Opinion Vo. 6, loc. cit. above (n, 5), p. I5 I 2 . See generally Craven, 'What's in a Name? The Former Yugoslav Republic of . Macedonia and Issues of Statehood', Australian Yearbook of International Lau, 15 (1995), p. I.

${ }_{3.1}$ Keesing's, vol. $3^{8}$, p. 38734 (1992); vol. 39, p. 39328 (1 993). Statement of Greek Government Spokesperson, 17 April 1992, cited in Ioannou, The Question of Recognition of Skopje (1992), p. 77. See generally Perry, 'Macedonia: From Independence to Recognition', RFE/RL Research Reports, 3 (1994), p. 1 I 8.

2.32 Opinion No. 10, loc. cit. above (n. 5), p. 1526. 
FRY. ${ }^{233}$ It noted, in that respect, that UN Security Council Resolutions 752 and 757 (1992) contained references to 'the former SFRY'. ${ }^{234}$ More important, however, was the fact that in Resolution 757 (1992), the Security Council noted that 'the claim by the Federal Republic of Yugoslavia (Serbia and Montenegro) to continue automatically (the membership) of the former Socialist Federal Republic of Yugoslavia (in the United Nations) has not been generally accepted'. ${ }^{235}$ This point was reinforced in Opinions 9 and 10 . In Opinion 9 the Commission, in outlining the basis upon which the succession of States should be based, noted that the European Council had demonstrated its conviction that the FRY should not be considered the sole successor (or what should properly be regarded as the continuation) of the SFRY. It recalled in particular the Council's Lisbon declaration, in which it was stated that:

the community will not recognize the new federal entity comprising Serbia and Montenegro as the successor State of the former Yugoslavia until the moment that decision has been taken by the qualified international institutions. They have decided to demand the suspension of the delegation of Yugoslavia at the CSCE and other international fora and organizations. ${ }^{236}$

It followed, as was made clear in Opinion 10, that the FRY does not ipso facto enjoy the recognition enjoyed by the SFRY and that it is therefore for other States to recognize it as a State under international law. ${ }^{237}$ It added that with respect to EC Member States, recognition would be conditioned upon its compliance with the requirements laid down in the Guidelines of 16 December 1991 . $^{238}$

The position adopted by the Arbitration Commission in these later opinions flowed inexorably from its findings in its first opinion. As soon as the Commission had declared the SFRY to be in the process of dismemberment', unless some extraordinary reversal of events had subsequently taken place, it followed that the extinction of the SFRY would occur, that the FRY could not thereby claim to be its continuation, and that so long as it fulfilled the necessary conditions it would have to be considered a new State under international law. That it has neither received nor sought recognition does not affect this conclusion, as the Arbitration Commission appeared to admit.

The Arbitration Commission's views have since been mirrored in the

2.3. At the time of the proclamation of the FRY on 27 April 1992 a declaration was issued proclaiming the FRY to be the continuation of the SFRY: see case concerning Application of the Convention on the Prevention and Punishment of the Crime of Genocide (Bosnia-Herzegovina v. Yugoslavia (Serbia and Montenegro)), ICY Reports, 1993, p. 3, at p. 15.

s3. Opinion No. 8, loc. cit, above (n. 5), p. 1523.

s.s Ibid.

236 Opinion No. 9, loc. cit. above (n. 5), p. 1524.

237 Opinion No. 10, loc. cit. above (n. 5), p. 1526 .

2.38 Ibid. 
practice of the UN. In Resolution 777 (1992) the Security Council noted that 'the State formerly known as the Socialist Federal Republic of Yugoslavia has ceased to exist' and that the 'Federal Republic of Yugoslavia (Serbia and Montenegro) cannot continue automatically the membership of the former Socialist Federal Republic of Yugoslavia in the United Nations; and therefore recommends to the General Assembly that it decide that the Federal Republic of Yugoslavia (Serbia and Montenegro) should apply for membership in the United Nations and that it shall not participate in the work of the General Assembly'. ${ }^{239}$ 'The General Assembly responded by adopting Resolution $47 / 1$, in which it noted that 'the Federal Republic of Yugoslavia (Serbia and Montenegro) cannot continue automatically the membership of the former Socialist Federal Republic of Yugoslavia in the United Nations', and resolved that it should not participate in the work of the General Assembly. ${ }^{2+0}$

The UN Legal Counsel explained the implications of General Assembly Resolution $47 / 1$ in the following terms:

the only practical consequence that the resolution draws is that the Federal Republic of Yugoslavia (Serbia and Montenegro) shall not participate in the work of the General Assembly. It is clear, therefore, that representatives of the Federal Republic of Yugoslavia (Serbia and Montenegro) can no longer participate in the work of the General Assembly, its subsidiary organs, nor conferences and meetings convened by it.

On the other hand, the resolution neither terminates nor suspends Yugoslavia's membership in the Organization. Consequently, the seat and nameplate remain as before, but in Assembly bodies representatives of the Federal Republic of Yugoslavia (Serbia and Montenegro) cannot sit behind the sign 'Yugoslavia'. Yugoslav missions at United Nations Headquarters and offices may continue to function and may receive and circulate documents. At Headquarters, the Secretariat will continue to fly the flag of the old Yugoslavia as it is the last flag of Yugoslavia used by the Secretariat. The resolution does not take away the right of Yugoslavia to participate in the work of organs other than Assembly bodies. The admission to the United Nations of a new Yugoslavia under Article 4 of the Charter will terminate the situation created by resolution $47 / 1 .^{241}$

As the ICJ noted, the solution adopted by the UN 'is not free from legal difficulties' ${ }^{2+2}$ Apart from the limited scope of the resolution, a matter which was later rectified by an additional resolution excluding the FRY

239 SC. Resn. 777 (1992), 19 September 1992.

340 GA Resn. 47/1, Genteral Assembly Official Records, 47th Session, Agenda Item 8, UN Doc. A/47/L.I and Add. I (1992).

${ }_{241}$ UN Doc. A/47/485.

${ }^{242}$ Case concerning, Application of the Convention on the Prevention and Punishment of the Crime of Genocide (Bosnia-Herzegovina v. Yugoslavia (Serbia and Montenegro)), ICJ Reports, 1993, p. 3, at p. I4. See Gray, 'Application of the Convention on the Prevention and Punishment of the Crime of Genocide (Bosnia and Herzegovina v. Yugoslavia (Serbia and Montenegro))', International and Comparative Law Quarterly, 43 (1994), p. 704, at pp. 707-10. 
from participation in ECOSOC, ${ }^{2+3}$ it appears to allow for the continued existence of an extremely ambiguous situation. ${ }^{244}$ If, as the Legal Counsel suggests, the membership of Yugoslavia in the UN is retained, one may question whether that implies that the SFRY continues to exist as a State in a manner reminiscent of India after the secession of Pakistan. ${ }^{2+5}$ Certainly for operational purposes that appears to be the case ${ }^{246}$ but it is otherwise inconsistent with the non-participation of the FRY. Similarly, although the opinion suggests that the admission of a 'new Yugoslavia' would terminate the situation created by Resolution $47 / 1$, that itself is open to question. If the FRY were to be admitted to the UN under Article 4, one may wonder why that would affect the (admittedly fictitious) membership of the SFRY, unless, contrary to what has been asserted, it was indeed the continuation of the SFRY. If, on the other hand and against all odds, Yugoslavia were to recreate itself, one would assume that, as in the case of Syria in 1962,247 it would resume its membership without having to re-apply. In the final analysis, the matter would be clarified only if the membership of Yugoslavia in the UN were to be officially terminated and the participation of the FRY completely eliminated.

Whatever the residual ambiguities in the position adopted by the UN, it is difficult to see practice as showing anything other than the extinction of the legal personality of the SFRY. To some extent, that situation was determined by the Arbitration Commission, which saw fit to proclaim

${ }^{243}$ GA Resn. 47/229 (1993), 29 April 1993, pursuant to SC Resn. 821 (1993), 28 April 1993.

${ }^{244}$ See Blum, 'UN Membership of the "New" Yugoslavia: Continuity or Break?', American fournal of International Law, 86 (1992), p. 830; Lloyd, 'Succession, Secession, and State Membership in the United Nations', New York University Yournal of International Law and Politics, 26 (1994), p. 76r.

${ }_{2+5}$ On that occasion the General Assembly First Committee agreed to the following formulation to govern the question of admission:

'I. That as a general principle, it is in conformity with legal principles to presume that a State which is a member of the organization of the United Nations does not cease to be a member simply because its constitution or its frontier have been subjected to changes, and that the extinction of the State as a legal personality recognized in the international order must be shown before its rights and obligations can be considered thereby to have ceased to exist;

2. That when a new State is created, whatever may be the territory and the populations which it comprises and whether or not they formed part of a State member of the United Nations, it cannot under the system of the Charter claim the status of a member of the United Nations unless it has been formally admitted as such in conformity with the provisions of the Charter;

3. Beyond that, each case must be judged according to its merits.'

(UN Doc. A/C.1/212, 1 I October 1947.) See generally Schachter, "The Development of International Law through the Legal Opinions of the United Nations Secretariat', this Year Book, 25 (1948), p. 91.

${ }^{2+6}$ The Secretariat has resisted the complete expulsion of the FRY from the organization because of the practical consequences it might have for the peace initiatives and other deliberations within the Conference on Yugoslavia: see UN Doc. A/48/847 (1993).

${ }^{247}$ Syria was able to revive its United Nations membership on seceding from the UAR without the need for readmission: Young, loc. cit. above (n. 145). Crawford argues, however, that in so far as the existence of Syria had been expunged by mutual consent on its entry into the UAR, its subsequent assertion of identity 'takes on decidedly fictional overtones': op. cit. above ( $n, 47)$, p. 408. 
the dissolution of the Federation in December 1991 and which laid the ground for the subsequent recognition of the emergent Republics by other members of the international community. The determinants of dismemberment outlined by the Commission were arguably somewhat superficial and were applied in an unnecessarily formulaic manner. Little consideration was given to the formal continuance of the Federation and its organs (albeit in a mutilated form), or to their claim to sovereignty over the territory. Similarly, in the early stages, the absence of diplomatic recognition was effectively overlooked, it being considered to be strictly declaratory and therefore irrelevant to any determination as to a State's existence or demise. In the circumstances, this was patently unrealistic. The facts in question were never sufficiently clear to render any opinion as to the legal situation beyond doubt. The fact of diplomatic recognition was undoubtedly highly 'constitutive' as regards Bosnia-Herzegovina and also perhaps Croatia. Having said that, as a case of dismemberment, the significant factors in the case of Yugoslavia (that perhaps distinguish it from the USSR) appear to have been the extent of territory and population lost in virtue of the disassociation of the various Republics, the fact that the Federation and its organs had to be legally reconstituted as a result, and the widespread conviction that the FRY could not automatically assume the membership of the SFRY in international organizations.

\subsubsection{Dismemberment and the statehood of the emergent Republics}

As a brief comment before considering the Arbitration Commission's approach to the acquisition of statehood by the Yugoslav Republics, it is worth noting that in established doctrine, although a necessary link is made between the expiry of one State and the rights and obligations that arise for the emergent entities, it has rarely been recognized that there should be any necessary interrelationship between the legal extinction of one State and the acquisition of personality by another in its place. Crawford, for example, although briefly considering the question of extinction,,$^{24^{8}}$ does not directly address the implications of dismemberment on the acquisition of personality by the emergent entities. Rather he refers exclusively to two main processes-devolution and secessionboth of which apparently assume the continued existence of the parent State. ${ }^{249}$ Marek, by contrast, considers in depth the question of dismemberment, but does not address whether that fact has any impact upon the acquisition of statehood by an emergent entity. ${ }^{250}$

One does not have to go too far to find an explanation. Generally speaking, unless an explicit process of devolution is at work, the process

\footnotetext{
*4 Crawford, op. cit. above (n. 47), pp. 417-20.

$24 \%$ Ibid., pp. $215-70$.

250 . Marek, op. cit. above (n. 132), passin.
} 
by which an entity acquires or loses statehood is shrouded by doubt, both as regards the relevant factual circumstances and as to their legal significance. It is therefore only when nascent entities come to be recognized as States by other members of the international community that these issues will be presumptively resolved. Accordingly, the demise of one State and the emergence of another in its place involve a single set of events which cannot be conceptually separated. At the same time, as a matter of policy it is not convenient to admit the possibility of an 'interregnum', or a discontinuity in responsibility for a piece of territory, as might emerge between the extinction of one entity and the emergence of another in its place, not least because the rights and duties of third States might be put at risk during the intervening period. It is therefore the practice that the extinction of a State will only be signalled once a view has been taken as to its presumptive successors. ${ }^{251}$

The Arbitration Commission, by force of circumstances one might presume, appeared to reverse this natural sequence of events by identifying the dissolution of the Federation (albeit in the form of a process) before the acquisition of statehood of the emergent entities could clearly be established beyond doubt. ${ }^{252}$ It subsequently attempted to rationalize the decision by retroactively dating the time of succession (and a fortiori the date of acquisition of statehood) of most Republics some time before their recognition by the international community. ${ }^{253}$ This is certainly consistent with the declaratory approach to recognition, which the Commission itself endorsed, in which the date of commencement of statehood is to be divined by reference to the existence of factual criteria and not to the discretionary acts of the recognizing States. On this view, even if 'retroactivity' has no place in the context of statehood (to the extent that late recognition of an entity is essentially superfluous ${ }^{254}$ ), it may serve to give legal recognition to a factual situation which was only concretized by subsequent events. As Crawford notes:

[A]n entity whose status is doubtful at a particular time may well, if it becomes definitively established or generally recognized as a State, be regarded as having been a State also at that earlier time: in such cases, subsequent events are capable of giving form to a state of affairs which would otherwise have been equivocal. ${ }^{255}$

25. This is consistent with the view that States tend not to withdraw recognition from States (as distinct from governments) but rather merely to recognize the successor State: above, n. 251 .

${ }_{25 x}$ It is suggested that the 'doubt' was only removed once Croatia and Slovenia were recognized by the EC Member States on 15 January 1992: Keesing's, vol, 38, p. 38703 (1992).

25. Opinion No. 11, loc. cit. above (n. 8), p. 1589. Although it might be considered that the Arbitration Commission was creating problems for itself by identifying specific dates of succession, as indeed it recognized itself (ibid., p. 1588 ), it is nevertheless considered an undertaking that is suited to judicial determination: see Chen, op. cit. above (n. 176), pp. 176-7. See, e.g., decision of International Commission of Jurists in the Aaland Islands case, League of Nations Official Yournal, I920, Special Supplement No. 3 .

${ }_{25+}$ Brownlie, op. cit. above (n. $3^{8)}$, p. 95.

2ss Crawford, op. cit. above (n. 47), p. 389 . 
As Crawford explains, it is the 'relatively conservative' operation of rules relating to the acquisition of statehood by secession which have encouraged international tribunals to date the commencement of the State from the 'earliest date at which it could be said to have been effectively in control of its territory'. ${ }^{256}$ What is clear from the Yugoslav situation, however, is that the 'conservative' rules regarding secession were not applied, not least because there remained considerable doubt about the effectiveness of the control exercised by the Croatian and BosniaHerzegovinian Governments even at the time of their recognition. ${ }^{257}$ Only in the case of Macedonia, which was recognized following its admittance to the United Nations in April I 993, is there a strong case for retroactivity. ${ }^{25} 8$

The problems posed by the Commission's chronology are compounded by the fact that when the dates of succession provided by the Commission are analysed, they are not entirely consistent with the conclusions posited in its first opinion. According to the Commission, Croatia and Slovenia acquired statehood on 8 October r 991, Macedonia on 17 November 1991, Bosnia-Herzegovina on 6 March 1992, and Serbia-Montenegro on 27 April $1992 .{ }^{259}$ As it also determined that the process of disintegration started on 29 November $1991,{ }^{260}$ it is difficult to view Croatia's and Slovenia's declarations of independence as anything other than acts of secession. Indeed, ironically enough, it also appears that Macedonia's independence is the result of an act of secession. Only Bosnia-Herzegovina and the FRY can be seen to have emerged once the process of dismemberment was under way. Such problems underline the arbitrary and reductive nature of legal chronologies and demonstrate the difficulties of differentiating between cases of secession and dismemberment. That the Commission was apparently indifferent to the problems of chronology may be understandable, but its insistence on

256" Ibid., p. 390 . He cites as an example the practice of mixed arbitral tribunals of holding that the various States formed after the World War I came into existence prior to the relevant peace treaties, e.g. Deutsche Cominental Gas-Gesellschaft v. Polish State (r920), Anmual Digest, vol. 2, No. 5 .

*57 The EC Member States recognized Croatia on 15 January 1992: Keesing's, vol. 38, no. 1, p. 38703 (1992). At that time, the Serbian Republic of Krajina (formerly the two Autonomous Regions of Krajina and Slavonia, Baranja and Western Srem), which amounted to approximately. one third of Croatian territory, was effectively entirely independent. It was recognized by Serbia on 20 December 1991: Keesing's, vol. 37, p. 38685 (1991). Similarly Bosnia-Herzegovina was recognized on 6 April 1992 , despite the existence of the self-proclaimed Republic of the Serbian People of Bosnia-Herzegovina: Keesing's, vol. 38, pp. 38704, 38833 (1992).

${ }_{25}$ In Opinion No. 6, the Arbitration Commission opined that FYROMI had fulfilled the necessary requirements for recognition: loc. cit. above (n. 5), p. 1512. Although it was concerned primarily with compliance with the EC recognition guidelines, one might suppose that no such recommendation would be given if the Republic did not fulfil the basic criteria for statehood. FYROM was admitted to the UN on 8 April 1993 under a provisional name: Keesing's, vol. 39 , p. 39442 (1993)

24" Opinion No. I I, loc. cit above (n. 8), p. 1589 .

2to Ibid., p. 1587 
different dates for accession to independence undoubtedly complicates the issues of succession that arise. ${ }^{26_{1}}$

Leaving aside the Commission's asserted chronology of events, it may be argued that the significance of identifying the process as one of dismemberment was that it enabled the statehood of the Republics to be established with considerably greater ease. According to traditional doctrine, the normal requirements for statehood are applied more strictly in cases of secession, where the emergent entities have to show considerably higher levels of effectiveness, than would be required in a case of devolution. ${ }^{262}$ The primary distinguishing feature in cases of devolution is the consent of the parent State, which serves to confer territorial sovereignty upon the new entity and provides it with a prima facie right to govern its territory as a State. ${ }^{263}$ Thus, in 1960 , the Congo was admitted to membership of the UN primarily on the basis of the agreement of Belgium and despite the fact that its government was struggling to prevent the Katangese secession and can hardly be said to have been in effective control of the territory. ${ }^{26+}$ Where no such agreement is evident, the seceding entity has to struggle to establish effective control in face of a presumption in favour of the integrity and effectiveness of the parent State. ${ }^{265}$ For example, in the cases of Katanga and Biafra, even though the secessionist units exercised significant control over the disputed territory, the majority of States refused to accord them recognition out of deference to the sovereignty of the respective parent States (the Congo and Nigeria). ${ }^{266}$ Indeed, as Lauterpacht noted, in cases of secession, recognition will only be legitimate once it is clear that the parent State is unlikely to be able to reassert control. ${ }^{267}$

The emergence of the new States in Yugoslavia cannot be seen as the result of a process of devolution in that, throughout the operative period, the Federation consistently opposed the intended secession of the various

26. Below, n. 369

2f: Devolution can be either 'partial' or 'universal'. 'The former involves the 'consensual' secession of a territorial unit, leaving the State otherwise intact. The latter involves the voluntary unification of two States or the separation of a whole State (as opposed to merely parts of a State) to form a new international person, e.g., the merger of Egypt and Syria to form the United Arab Republic in 1958; the merger of the People's Democratic Republic of Yemen and the Yemen Arab Republic to form the Republic of Yemen in 1990; the separation of Czechoslovakia into the Czech and Slovak Republics on 1 January 1993.

${ }^{213}$ Crawford, op. cit. above (n. 47), pp. 44, 218 . He identifies a number of exceptions to this rule, however, particularly as regards grants of independence in violation of the principle of selfdetermination: ibid, pp. 219-22.

26, See Shaw, op. cit. above (n. 146), pp. 202-8.

2trs Ibid., pp. $214-16$.

abo Biafra was recognized only by Tanzania, Gabon, the Ivory Coast and 7ambia. Even then, recognition appears to have been accorded for 'humanitarian' reasons: see Shaw, ibid., pp. 200-10. Similarly, the General Assembly condemned the attempted secession of Mayotte as a violation of the sovereignty and territorial integrity of the Comoros: GA Resn. 31/4, 21 October 1971; GA Resn. 45/11, II November 1990.

2m7 Lauterpacht, op. cit. above (n. 176), p. 45. 
Republics. ${ }^{268}$ Equally, although the Constitution of the SFRY did explicitly embody a right to secession, ${ }^{269}$ that it served to provide legitimacy for the acts of the various Republics is extremely doubtful. Strictly speaking the constitutional right to self-determination and secession belonged to the respective 'nations' rather than to the Republics themselves. ${ }^{270}$ As none of the constituent Republics (with the possible exception of Slovenia) was nationally homogenous, it was questionable whether the right devolved upon the Republics themselves. Moreover, there was never any agreement as to the precise implication of the right to secession, ${ }^{271}$ there being doubt, for example, as to whether or not it could have been exercised by means of a unilateral act. ${ }^{272}$

Given the non-consensual nature of the acts of independence, one might have expected that a presumption would be operated in favour of the effectiveness of the federal government, and correspondingly against that of the seceding Republics. Nevertheless, the international community was willing to afford diplomatic recognition to Slovenia, Croatia, and Bosnia-Herzegovina at an early stage and in spite of an obvious lack of effectiveness in the latter two cases. ${ }^{273}$ To some extent, the advice of

264 On 24 June 1991 the Yugoslav Prime Minister warned that the Federal Government will use all means available to stop the republics' unilateral steps towards independence': cited in Weller, loc, cit. above (n. 13), p. 570. The FRY did eventually recognize Slovenia in 1992: Keesing's, vol. 38 , p. 39036 ( 1992 ).

260 The 1974 Yugoslav Constitution provided (Basic Principles 1, para. 1): "The nations of Yugoslavia, proceeding from the right of every nation to self-determination, including the right to secession, on the basis of their will freely expressed in the common struggle of all nations and nationalities... have, together with the nationalities with which they live, united in a federal republic of free and equal nations and nationalities and founded a socialist federal community of working people - the Socialist Federal Republic of Yugoslavia'.

270 This also excludes a right of secession on behalf of 'nationalities' (i.e. the Albanians in Kosoro and the Hungarians in Vojvodina): see Rich, loc. cit. above (n. 118), pp. $3^{8-9}$. Serbia adopted the position that the proper subjects of any political settlement are not the republics or provinces, but rather the South Slav nations. Accordingly, it considered the internal borders of Yugoslavia to be administrative rather than political, and therefore claimed the right to represent Serbs irrespective of where they lived. Serbia officially committed itself to the annexation of parts of Croatia, BosniaHerzegovina and Macedonia in the event of the federation being replaced by a looser State structure: Magas, op. cit. above (n. 193), pp. 275-6.

${ }_{271}$ 'The right to secede was set alongside a duty to ensure the 'unity of the political system' (Art. 244). As Singleton comments: "The legal theory behind the federal structure is that the separate South Slav peoples voluntarily acceded to the [SFRY] and have the right of self-determination .. . [However] the possibility that any of them should excrcise the right to secession is politically unthinkable': A Short History of the Yugoslav Peoples (1985), p. 210 . It is pertinent to note that Article 1 of the 1946 Yugoslav Constitution, which is the predecessor of the 1974 Constitution, described the Federal Republic as 'a community of peoples equal in rights who, on the basis of the right to self-determination, including the right of scparation, have expressed their will to live together in a federative State'. 'I'his apparently reflects the idea that self-determination has already been exercised in the creation of the Federation.

${ }_{272}$ See generally Bagwell, 'Yugoslavian Constitutional Questions: Self-Determination and Secession of Member Republics', Georgia Yournal of International and Comparative Lawo, 21 (1991), p. 489; Iglar, 'The Constitutional Crisis in Yugoslavia and the International Law of Self-Determination: Slovenia's and Croatia's Right to Secede', Boston College International and Comparatiz'e Lazv Review, 15 (1992), p. 213 , at pp. $218-21$.

27. Above, n. 257. 
the Arbitration Commission was ignored on this point. Despite the Arbitration Commission's concern that Croatia had not fully incorporated the provisions on the 'special status' of minorities, ${ }^{274}$ the EC Member States proceeded to afford it recognition. ${ }^{275}$ Similarly, although the Republic of Macedonia was found to have fulfilled the EC Guidelines on recognition, ${ }^{276}$ it was refused recognition by the EC Member States on the basis that 'more important issues' had to be resolved. ${ }^{277}$ That being said, it is clear that considerable deference was given to the Commission's view that the federation was in the process of dismemberment. Indeed, it may be directly as a result of that finding that the precipitous recognition of Bosnia-Herzegovina and Croatia is to be explained. If this reasoning is accepted, it could be suggested that once an entity asserts its independence as against a State which shows itself to be in the process of dismemberment (in virtue of the effective, simultaneous, disassociation of the majority of the constituent territorial units), no presumption will operate in favour of the sovereignty of the parent State and the nascent entity will be able to establish its statehood with relative ease. Such a case might in practice be assimilated to one in which the parent State had specifically consented to the act of independence, or perhaps even one in which the principle of self-determination was operative. ${ }^{278}$

\subsection{Self-Determination}

The fact that the various Republics attained statehood following acts of independence which recalled in no uncertain terms the principle of self-determination ${ }^{279}$ has prompted a number of commentators to consider the applicability of self-determination to the situation of Yugosla$\mathrm{via}^{280}$ and more generally to consider its relevance in the post-colonial

${ }^{27+}$ Opinion No. 2, loc. cit. above (n. 5), p. 1505.

275 Croatia was recognized by the EC Member States on 15 January 1992: Keesing's, vol. $3^{8}$, p. 38703 (1992). It was admitted to the U.V on 22 May 1992: Keesing's, vol. 38 , p. 38918 (1992). Weller suggests that recognition was accorded because the EC's insistence on constitutional guarantees exceeded the standard adopted among many EC Member States: loc, cit, above (n. I3), p. 593 .

${ }_{276}$ Opinion No. 6, loc. cit. above (n. 5), p. 1511 .

277 Keesing's, vol. 38, p. 38704 (1992). Macedonia was ultimately admitted to the UN in April 1993 under the provisional name 'the Former Yugoslav Republic of Macedonia': Keesing's, vol. 39, pp. 39328, 39422 (1993). Six States of the EC established diplomatic relations with Macedonia in December: Keesing's, vol. 39, p. 39785 (1993).

${ }^{278}$ 'The only obvious exception on this point being the case of Macedonia. It is considered, however, that Macedonia should be treated as having acquired independent Statehood in early 1992, the delay in recognition being solely due to Greek intransigence on the question of its name. Above, n. 258 .

${ }^{279}$ Above, n. I4I.

280 See, e.g., Mullerson, International Law, Rights and Politics (1994), pp. 58-91; Iglar, loc. cit. above (n. 272); Franck, 'Fairness to "Peoples" and their Right to Self-Determination', Recueil des cours, 240 (1993-111), p. 125; Koskenniemi, 'National Self-Determination Today: Problems of Legal 'Theory and Practice', International and Comparative Law Quarterly', 43 (1994), p. 24 I. 
era. ${ }^{2{ }_{1}}$ The Arbitration Commission did not directly consider the applicability of the principle of self-determination in relation to the acts of independence of the various Republics. Indeed, it appears to have implicitly rejected the relevance of self-determination as a determining factor in the acquisition of statehood. It did, however, make a number of broad pronouncements upon the subject which were a mixture of the cautious and the controversial.

In its first opinion, while discussing the question of the dismemberment of the SFRY, the Commission obliquely referred to self-determination by asserting that all successor States to the Federation would be bound by 'the peremptory norms of general international law and, in particular, respect for the fundamental rights of the individual and the rights of peoples and minorities'. ${ }^{2 x_{2}}$ Leaving aside the question of fundamental individual rights and the rights of minorities, both of which raise specific problems with respect to their status as 'peremptory norms', the first issue is what is meant by 'the rights of peoples'. Although a number of rights, such as the right to peace, the right to development and the right to a clean environment, have all been posited in the category of 'peoples' rights', it has rarely been suggested that they also have the status of norms of jus cogens to which the Commission referred. One can only assume that the Arbitration Commission specifically had in mind the right to self-determination for which there is greater, albeit somewhat equivocal, support as a norm of jus cogens. If this is the case, however, one might wonder why the Commission was not specific on the point.

The existence of a category of norms having the status of jus cogens, although relatively recent, is now widely accepted. ${ }^{283}$ Its classical statement is found in Article 53 of the Vienna Convention on the Law of Treaties, which provides:

${ }_{2 \mathrm{H}}$. See, e.g., Cassese, Self-Detemination of Peoples: A Legal Reappraisal (1995); McCorquodale, 'Self-Determination: A Human Rights Approach', International and Comparative Law Quarterly, 43 (1994), p. 857 .

${ }_{2 K_{2}}$ Opinion No. 1 , loc, cit. above (n. 5), p. 1496.

${ }_{24}$ See generally Verdross, 'Gus dispositivum and jus cogens in International Law', American Yournal of International Law, 60 (1966), p. 55; Virally, "Réfexions sur le "jus cogens" ", Annuaire franfais de droit international, 12 (1966), p. 5; Onuf and Birney, 'Peremptory Norms of International Law: Their Source, Function and Future', Denver fournal of International Law and Policy,4 (1974), p. 187; Hannikainen, Peremptory Norms (Fus Cogens) in International Law (1988). The International Law Commission's commentary notes: "The view that in the last analysis there is no rule of international law from which states cannot at their own free will contract out has become increasingly difficult to sustain... The Commission pointed out that the law of the Charter concerning the prohibition of the use of force in itself constitutes a conspicuous example of a rule in international law having the character of jus cogens. Moreover, if some governments in their comments have expressed doubts as to the advisability of the article . . only one questioned the existence of rules of jus cogens in the international law of today': Yearbook of the $I L C, 1966$, vol. 2 , p. 247. For a sceptical view, see Schwarzenberger, 'International "Jus Cogens"?', Tulane Law Review, 43 (1965), p. 455 . 
A treaty is void if, at the time of its conclusion, it conflicts with a peremptory norm of general international law, For the purposes of the present Convention, a peremptory norm of general international law is a norm accepted and recognized by the international community of States as a whole as a norm from which no derogation is permitted and which can be modified only by a subsequent norm of general international law having the same character. ${ }^{28_{4}}$

Without entering into a detailed discussion of the nature of norms of $j u s$ cogens, it is generally considered that the main difficulty attached to the notion is that of its content and field of application. ${ }^{28_{5}}$ This is nowhere more evident than in the debate over self-determination. ${ }^{286}$ A number of commentators have asserted the peremptory nature of self-determination, ${ }^{287}$ support for which is found in the work of the International Law Commission $^{288}$ and the separate opinion of Judge Ammoun in the Barcelona Traction case. ${ }^{28,}$ However, even if it is accepted that selfdetermination operates as a peremptory norm in the context of decolonization, ${ }^{200}$ it is not yet clear whether its application outside that limited

$2 x_{*}$ Vienna Convention on the Law of Treaties (1969). Article 64 also provides: 'If a new peremptory norm of general international law emerges, any existing treaty which is in contlict with that norm becomes void and terminates'. See Sztucki, Jus Cogens and the Vienna Convention an the Law of Treaties (1974); Rosenne, The Law of Treaties (1970), pp. 290-3; Sinclair, The Vienna Convention on the Law of Treaties (2nd edn., 1984), pp. 203-41.

2ns The ILC feit constrained to mention just three examples of jus cogens norms: '( $a)$ a treaty" contemplating an unlawful use of force contrary to the principles of the Charter, (b) a treaty contemplating the performance of any other act criminal under international law, and (c) a treaty contemplating or conniving at the commission of acts, such as trade in slaves, piracy or genocide, in the suppression of which every state is called upon to co-operate': Yearbook of the ILC, 1966, vol. 2, p. 248 .

2sh The 'legal' basis of the right to self-determination is founded in a range of legal texts including: UN Charter, Art. 1, para. 1; International Covenant on Civil and Political Rights, Art. 1; International Covenant on Economic, Social and Cultural Rights, Art. r; Helsinki Final Act 1975, Part VIII, International Legal Materials, 14 (1975), p. 59; African Charter on Human and Peoples' Rights 1981, Art. 20; G.A Resn. 1514, General Assembly Official Records, 15 th Session, Supplement No. 16, p. 66, UN Doc. A/4684 (1960); GA. Resn. 2625, ibid., $25^{\text {th }}$ Session, Supplement No. 28 , p. $12 \mathrm{t}$, UN Doc. A/8028 ( 1970 ). The ICJ has also recognized the right to self-determination: see advisory opinion on the Legal Consequences for States of the Contimed Presence of South Africa in Namibia (South West Africa) notwithstanding Security Council Resolution 276 (1970) (Namibia case), ICJ Reports, 1971, p. 16, at p. 31, and Western Sahara case, ICJ Reports, 1975, p. 12, at p. 31. See generally Cristescu, The Right of Self-Determination: Historical and Current Development on the Basis of United Nations Instruments (1981).

${ }^{2 H 7}$ Cassese, Self-Determination of Peoples (1995), pp. 133-40, 169-74; Gros Espiel, 'SclfDetermination as Yus Cogens', in Cassese (ed.), UN Law/Fundamental Rights (1 979), p. 168; Dugard, Recognition and the United Nations (1987), pp. 158-62; Hannikainen, op. cit, above (n. 283), Pp. 421-4; Salo, 'Self-Determination: An Overview of History and Present State with Emphasis on the CSCE Process', Finnish Yearbook of International Law, 2 (t99t), p. 307.

28* Yearbook of the ILC, 1966, vol. 2, p. 248; ibid., 1976, vol. 2, part 2, p. 95.

2k, ICJ Reports, 1970, p. 3, at pp. 304, 312. Judge Ammoun again referred to the imperative character of the right of peoples to self-determination" in the Namibia case, ICY Reports, 1971, p. 16, at pp. $72-5$.

290 The approach of the international community with respect to Southern Rhodesia, for example, might be considered to provide evidence that self-determination, as a norm of jus cogens, serves to vitiate statehood in cases where it is asserted in violation of an applicable principle of representativity: see Dugard, op. cit. above (n. 287), pp. 123-63; Hannikainen, op. cit. above (n. 283), 
context can be said to be peremptory in nature. ${ }^{29 t}$ This problem may be addressed either by severely limiting the definition of the entitlement holders (i.e. the 'peoples' to which the principle refers) or by accepting that it is an umbrella principle embodying a range of subsidiary rights and principles each of which might have differential status in international law (customary, conventional or peremptory). If the latter is the case, it is perhaps better to start speaking of discrete forms of selfdetermination, rather than using it as an all-encompassing notion.

As far as the Commission was concerned, in its first opinion it referred to self-determination as an operative principle for all successor States to the SFRY. As such, it was not apparently referring to self-determination as a principle governing the creation or modification of existing States or their borders, but rather to what has been termed the 'internal' dimension of self-determination ${ }^{29^{2}}$ which requires the creation, and operation, of participatory and representative mechanisms of government. ${ }^{20,3}$

pp. 357-424. Contra, Crawford, op. cit. above (n. 47), pp. 81-2. The principal problem in this context is whether or not the field of application of jus cogens is wider than the specific context of treaties: see Hannikainen, op. cit. above (n. 283), p. 9; Sztucki, op. cit above (n. 284 ), pp. 67-9.

Crawford argues that self-derermination is 'controversial even as jus dispositizum' and therefore the suggestion that it constitutes a norm of jus cogens is 'difficult to accept': op. cit. above (n. 47), p. 81; Sinclair, op. cit. above (n. 284), p. 217, n. 75 ; Pomerance, Self-Determination in Laz and Practice (1982), pp. 63-72. It is considered that such caution is no longer warranted. In the case concerning East Timor, the ICJ noted that the right of peoples to self-determination had an "erga ommes character' (loc. cit. above (n, 182), para. 29). While this suggests that it is more than merely part of the jus dispositivum, it does not resolve the question of its status as jus cogens. In tcrms of its scope of application, the court merely referred to self-determination as it evolved from the Charter and from United Nations practice' (ibid). 'This may argue in farour of its being limited broadly to the context of decolonization.

2w' Judge Dillard, e.g. in analy'sing the Namibia case concluded that self-determination as al norm of international law was "applicable to the decolonisation of those non-self-governing territories which are under the aegis of the United Nations': Western Sahara case, ICF Reports, 1975, p. 12, at p. I 2 I. Principle IV of GA Resn. 1541 (XV) defines non-self-governing territories as "a territory which is geographically separate and is distinct ethnically and/or culturally from the country administering it'. Crawford identities the following as units to which the principle of selfdetermination applies: (a) 'Trust and mandated teritories, and non-self-governing territories under Chapter XI of the Charter; (b) States, excluding those parts of States which are themselses selfdeternination units; $(c)$ (possibly) other territories forming distinct political-geographical areas, Whose inhabitants do not share in government with the result that they become non-self-governing; (d) all other territories or situations to which self-determination is applied by the parties as an appropriate solution or criterion: op. cit. above (n. 47), p. 101 .

21 See Cassese, 'Political Self-I Determination-Old Concepts and Vew Developments', in Cassese (cd.), UN Law/Fundamental Rights (1979), p. 1 37; Iliggins, Problems and Process (1994), pp. II $1-28$.

24,3 Principle VIII of the Helsinki Final Act, 1975 provides: 'By virtue of the principle of equal rights and self-determination of peoples, all people always have a right, in full freedom, to determine, when and as they wish, their internal and external political status, without interference, and to pursue as they wish their political, economic, social and cultural development': Intermational Legal Materials, $1+$ (1975), p. 1292. The Friendly Relations Declaration (GA Resn. 2625 (XXV), 24 Octuber 1970) implicity defines a self-determined State in a savings clause as one which is 'possessed of a government representing the whole people belonging to the territory without distinction as to race, creed or colour'. There is a possible connection here betwcen the Commission's approach to self-determination and its opinion as to the critcrion of effectiveness in the context of federal States: above, nn. 205-10. It can also be seen to have recognition in the EC guidelines on recognition: above, n. 205. 
Although this reflects an increasing preoccupation in the international community with the application of democratic principles both in terms of human rights treaty norms ${ }^{294}$ and more broadly in the practice of international relations, ${ }^{295}$ it may be questioned whether there is, as yet, sufficient evidence to suggest that a rule of internal self-determination is peremptory in nature. Such a conclusion is to some extent dependent upon the particular construction of jus cogens adopted. For example, it is probably not too difficult to accept the proposition that States must not derogate from a norm of internal self-determination in their conventional relations inter se. ${ }^{296}$ The suggestion that any derogation from the principle of internal self-determination is not only unlawful (as part of the jus dispositivum) but also amounts to an international crime, ${ }^{297}$ however, appears unsubstantiated in practice.

The Arbitration Commission came to consider the question of selfdetermination more directly in its second opinion. ${ }^{298}$ There, it was asked whether the Serbian population of Croatia and Bosnia-Herzegovina, 'as one of the constituent peoples of Yugoslavia', had the right to selfdetermination. ${ }^{299}$ The implications of this question were significant. At the time, Serbian populations in both Croatia and Bosnia-Herzegovina had declared their independence and had set up 'Serbian Autonomous Republics' in Krajina and Bosnia-Herzegovina, and like the other Republics were seeking international recognition as independent States. ${ }^{300}$ Although the Commission had decided that the SFRY was in the process of dismemberment, it had not identified how the new territorial entities were to be defined. In such circumstances, it was clearly the position of the Serbs that the principle of national selfdetermination should be the governing criterion and that it should be applied irrespective of the existing internal boundaries of the Federation. The Commission's response to this issue is in some respects quite remarkable.

Although it initially declared that international law as it currently stands does not spell out all the implications of the right to selfdetermination' ${ }^{301}$ the Commission went on to make two broad assertions

\footnotetext{
${ }^{294}$ e.g. Articles $I$ and 25 of the International Covenant on Civil and Political Rights, 1966, UN Treaty Series, vol. 999, p. 171.

${ }^{295}$ See Crawford, 'Democracy and International Law', this Year Book, 64 (1993), p. 113.

St Such a conclusion, however, is dependent upon acceptance of 'internal self-determination' as part of the jus dispositivum. For the argument that this is the proper understanding of selfdetermination, see Higgins, op. cit. above (n. 292), pp. I $18-21$.

297 It is in virtue of the distinction between 'crimes' and 'delicts' in international responsibility, that commentators have justified the application of jus cogens beyond the confines of treaty law: see Dugard, op. cit. above (n. 287), pp. 141-7. Cf. ILC Draft Articles on State Responsibility (Article 19), Yearbook of the $I L C, 1976$, vol. 2, pp. 95-122.

${ }^{204}$ Opinion No. 2, loc. cit. above (n. 5).

299 Ibid., p. 1498.

${ }_{300}$ Keesing's, vol. 37, p. $3^{8685}$ (1991).

3or Ibid.
} 
applicable respectively to the external and internal dimensions of selfdetermination. First, the Commission stated that 'whatever the circumstances, the right to self-determination must not involve changes to existing frontiers at the time of independence (uti possidetis juris) except where the States concerned agree otherwise'. ${ }^{302}$ Secondly, and by contrast, the Commission argued that in virtue of Article $I$ of the two International Covenants on Human Rights, the right to self-determination entailed a right of every individual 'to belong to whatever ethnic, religious or language community he or she wishes'. ${ }^{303}$ Neither of these assertions can be accepted in an unqualified form.

\subsubsection{External self-determination and uti possidetis}

As regards the first point, the Commission's line of thought is largely unexplained. Its argument that self-determination must not involve changes to existing frontiers at the time of independence can easily be accepted as regards established international borders. Most recent enunciations of self-determination have been accompanied by a corresponding confirmation of the integrity of existing international borders,${ }^{304}$ and there is little practice to suggest that the application of self-determination has justified the non-consensual re-drawing of such borders. In the context of Yugoslavia, for example, it was never suggested that the borders between Yugoslavia and Greece or Bulgaria could or should be redrawn on the basis of self-determination claims by peoples within Yugoslavia. One may note in that respect the considerable deference given to the Greek complaint that the Republic of Macedonia had irredentist designs over Northern Greece. The real question related to what were formerly the internal borders within the SFRY that demarcated the various Republics for administrative purposes. This matter was taken up by the Arbitration Commission in its third opinion (issued on the same day), in which it specifically addressed the question whether the internal boundaries between Croatia and Serbia and between BosniaHerzegovina and Serbia could be regarded as frontiers in terms of public international law. ${ }^{305}$ Expressly relying on the principles and rules of public international law, the Commission began by declaring that all external frontiers must be respected in line with the principle laid down in the UN Charter, in General Assembly Resolution 2625 (XXV) and in

.102 Ibid.

.10.3 Ibid.

304 Resolution 1514 (XV) provides that 'any attempt at the partial or total disruption of the national unity and the territorial integrity of a country is incompatible with the purposes and principles of the Charter of the UN": loc. cit above (n. 286). Resolution 2625 (XXV) provides that '[n]othing in the forcgoing paragraphs shall be construed as authorizing or encouraging any action which would dismember or impair, cotally or in part, the territorial integrity or political unity of sovereign and independent States': loc. cit. above (n. 286).

sos Opinion No. 3, loc. cit. above (n. 5). 
the Helsinki Final Act. ${ }^{306}$ It went on to state that the internal boundaries that were the subject of the question 'may not be altered except by agreement freely arrived at', and that they had become 'frontiers protected by international law'.307 In reaching this conclusion, the Commission invoked the principle of uti possidetis juris (which it took to be a general principle of international law) and quoted at length from the decision of the ICJ in the Burkina Faso and Mali Frontier Dispute case. ${ }^{308}$ In that case the Court had stated that the principle uti possidetis juris 'is a general principle, which is logically connected with the phenomenon of the obtaining of independence, wherever it occurs. Its obvious purpose is to prevent the independence and stability of new States being endangered by fratricidal struggles. '309 The Commission considered that this principle applied all the more readily to the Republics since Article 5(2) and (4) of the Constitution of the SFRY stipulated that the Republic's territories and boundaries could not be altered without their consent.

The decision of the Arbitration Commission on this point represents a novel extension of the uti possidetis principle outside the context of decolonization. Uti possidetis juris has arguably undergone a number of subtle changes in its evolution. ${ }^{310}$ As it was originally applied in the context of South America (a context to which some considered it to be restricted ${ }^{31}$ ), it was a means of establishing title to territory and of fixing boundaries in the unexplored hinterlands without having to wait for title to accrue through prescription. ${ }^{312}$ This was recognized in the Beagle Channel arbitration, ${ }^{313}$ where it was noted that $u t i$ possidetis encompassed two broad principles: first, a presumption that all territory is deemed to have been part of one of the former administrative divisions of colonial rule and that therefore that no territory would have the status of res nullius; and secondly, that the title to any given locality is deemed automatically to rest in whatever State took over the former administrative division in which it was situated. ${ }^{314}$ Accordingly it had a narrow

${ }_{104}$ Ibid., p. 1500 . It noted that this principle also underlies Article 1 i of the Vienna Convention on the Succession of States in respect of 'Treaties. That article provides that 'A succession of States does not as such affect: $(a)$ a boundary established by a treaty . . . : American Yournal of International Law, 72 ( 1978 ), p. 97 I.

307 Ibid.

108 ICY Reports, 1986, p. 554 .

son Ibid., p. $55^{6}$.

30 The principle originated in Roman Law in which it was used to denote an edict of the praetor used to preserve an existing state of possession pending litigation: see Fisher, 'The Arbitration of the Guatemalan-Honduran Boundary Dispute', American Fournal of Imternational Law, 27 (1933), p. 403, at p. 415. For its development in decolonization, see Frank, "Fairness to "Peoples" and their Right to Self-Determination', Receuil des cours, 240 (1993-III), p. 125, at pp. 129-34; Klabbers and Lefeber, 'Africa: Lost Between Self-Determination and Uti Possidetis', in Brolmann, Lefeber and Zieck (eds.), Peoples and Minorities in International Law (1993), p. 37.

"'Jessup, 'Diversity and Uniformity in the Law of Nations', American Journal of International Law, $58(1964)$, p. 341 , at p. 347 .

$3 \times 2$ O'Connell, op. cit. above (n. 125 ), p. 426.

$3: 3$ Beagle Channel arbitration (Argentina v. Chile), 52 ILR I2I.

w+ Ibid., p. I25. 
application in cases where the newly independent States had not in fact fully established effective control over the totality of the area of the former administrative division, and where the principle was used to prevent possible future conflict by laying down title to boundaries in advance. ${ }^{315}$ Even within this framework, however, problems arose with respect to the identification of the boundaries that were to be frozen. For example, in the Guatemala/Honduras arbitration the arbitrators were presented with two possible approaches, each advocated by one of the parties to the dispute. One party advocated the application of uti possidetis juris which relied upon the formal delimitation of frontiers by the colonial administrators; the other party advocated uti possidetis de jure which established title in virtue of actual possession as demonstrated in administrative practice. ${ }^{316}$ Although in that case greater emphasis was placed upon the fact of actual possession rather than the formal devolution of title, it is clear that practice in Latin America was not consistent on this point. ${ }^{317}$

In its application outside the Latin American context, the principle of uti possidetis (or what has been regarded as such) has taken on a number of different forms. On some occasions, it has been applied in the form of a doctrine of State succession to boundary treaties; ${ }^{318}$ on other occasions, it has been interpreted as reinforcing the notion of territorial integrity. ${ }^{319}$ Strictly speaking, both of these forms may be distinguished from the original notion of uti possidetis as employed in the process of decolonization, in which the existing administrative boundaries were transformed into boundaries protected by international law. ${ }^{320}$ That being said, it is clear that in Africa, the former colonial administrative borders have been largely preserved intact and have served to define the shape of subsequent independent States. ${ }^{321}$

"3. Cf. the defensive purpose and prevention purpose outlined by Abi-Saab (separate opinion) in Frontier Dispute case, loc. cit. above (n. 308), p. 659 .

"16 Reports of International Arbitral Awards, vol. 2, p. 1352. See Bloomfield, The British Honduras-Guatemala Dispute (1955); Fisher, loc. cit, above (n. 310 ).

317 See De Lapradelle, La Frontiere (1928), who, in light of the inconsistent practice, argues for the total abandonment of the concept. Hyde comments that 'the term uti possidetis was in reality a description of the practice that was being roughly followed. The Latin American States of Spanish origin did not at that time regard the phrase, despite its significance in Roman law or its place in the law of war, as expressive of a legal principle to which they owed deference or were endeavouring to conform in the establishment of new frontiers': International Law: Chiefly as Interpreted and Applied by the United States (1945), p. 501.

${ }^{3 \prime K}$ e.g. Guinea/Guinea-Bissau Maritime Delimitation case, 77 ILR 635, where it was stated that the 1886 boundary delimitation treaty 'remained in force between France and Portugal and became binding between the successor states by virtue of the principle of uti possidetis': p. 657; OAU Resolution on Border Disputes among African States,OAU Doc. AHG/Res. I6(1). Cf. Article I I, Vienna Convention on State Succession in Respect of Treaties (1978).

${ }^{319}$ e.g. as expressed in Article III(3) of the Charter of the OAU, 1963, UN Treaty Series, vol. 479,

p. 39; Principle IV, Helsinki Final Act (1975).

120 Frontier case, loc. cit. above (n. 308), p. 566.

${ }^{121}$ See generally Shaw, op. cit. above (n. 146). 
As far as the Arbitration Commission was concerned, in order to justify applying the principle uti possidetis in the context of Yugoslavia, it relied heavily upon the dictum of the ICJ in the Frontier case, to the effect that the principle was a general one 'logically connected with the phenomenon of obtaining of independence, wherever it occurs' (emphasis added). ${ }^{322}$ It should be noted, however, that however broadly-stated the proposition, the ICJ did not necessarily have in mind the application of uti possidetis to a situation such as that in Yugoslavia. Rather, its concern was merely to affirm that the principle was 'not a special rule which pertains solely to one specific system of international law', and could therefore apply to cases of decolonization other than those in Spanish America. In fact, later in the same judgment, when the Court reiterated the point, it specifically used the word 'decolonization' rather than the looser terms 'independence'. ${ }^{323}$ That some question remained as to whether uti possidetis was to be conceived properly as a principle of universal application is indicated in the separate opinion of Judge Luchaire, who warned that '[i]n legal discourse, the term "decolonization" should be used only with great caution and must above all not be confused with accession to independence' $.^{32}+\mathrm{He}$ continued: 'the colonial process must be regarded as finally over once the inhabitants of a colony have been able to exercise this right of self-determination'. ${ }^{325}$

However the judgment of the Court in the Frontier case is viewed, it is clear that the Arbitration Commission's determination that uti possidetis should apply to the case of Yugoslavia is significant and tends to reinforce a more expansive view of the principle's field of application. As a question of policy, there is a strong case for arguing that the application of uti possidetis to the Yugoslav situation was preferable, in the short term at least, to the delimitation of boundaries on the basis of unstable and shifting forces of nationalist sentiment, or on the basis of a strict application of the principle of effectiveness. One may question, nevertheless, whether in the long term it is a legal technique which will provide a permanent and pacific settlement to the underlying territorial disputes.

As a separate question of legal coherence, uti possidetis is only understandable when it is operated within an identifiable time-frame and with respect to identifiable units of statehood. As the Court in the Frontier case noted, '[i] t applies to the State as it is, ie. to the "photograph" of the territorial situation then existing. The principle of uti possidetis freezes the territorial title; it stops the clock, but does not

\footnotetext{
${ }^{12}$ Frontier case, loc. cit. above (n. 308 ), p. 565 .

123 Ibid., p. 566.

324 Ibid., p. 652 .

325 Ibid.
} 
put back the hands. ${ }^{326}$ In this regard, there are two particular problems that arise from its application in the context of Yugoslavia. First, the dismemberment of the SFRY as described by the Arbitration Commission did not, of itself, identify the units of government which were to be the presumptive States in the new territorial settlement. That would only be the case if the process were one of devolution or secession. Secondly, even if the original 'photograph of the territorial situation' were to be taken at the moment the Federation was proclaimed to be 'in the process of dissolution', that only effectively addresses the problem of border disputes that might arise between the various Republics. If uti possidetis is to apply to all cases of 'independence' there is nothing to preclude its further application within each of the Republics even after their statehood has been established.

Ultimately, two different processes are at work in each case. First, the identification of presumptive units of statehood, whether that be in virtue of the principle of effectiveness or self-determination, and secondly the determination of boundaries within which those entities are to be confined. ${ }^{327}$ The principle of uti possidetis, in its original guise, only serves to address the second question and does not provide a coherent basis for establishing the statehood of the emergent entities. The manner in which the Arbitration Commission addressed the issue, however, was to use uti possidetis as a tool for establishing the presumptive statehood of the entities to emerge from the dismemberment of the SFRY and to deny the autonomous Serbian Republics the benefit of that presumption.

If the Commission's first opinions are taken together as a coherent whole (which is not unreasonable given the fact that the first three were delivered on the same day), one is left with the view that owing to a collapse in central government the SFRY fell into a process of dismemberment in which, through application of the principle of uti possidetis, the succeeding entities were presumptively deemed to be the six Republics. This being the case, it is clear that the principle of selfdetermination had little overall influence on the territorial settlement. First, in terms of ethnicity, while Slovenia was relatively homogenous, all of the other Republics had significant ethnic minorities within their territorial borders which generally opposed the territorial settlement that

${ }^{326}$ Ibid., p. 568. Cf. Claims of Morocco over Western Sahara, Western Sahara case, ICY Pleadings, CR 75/8, pp. 11-16.

${ }_{327}$ This distinction is evident in the fact that in order to acquire statehood it is not necessary for the entity concerned to have its borders strictly determined, but rather that it should merely be in control of territory in an abstract sense. See Deutsche Continental Gas-Gesellschaft v. Polish State, Annual Digest, vol. 5, p. I , at p. I 5. It is arguable, however, that territory should not be 'excessively fragmented' as, e.g., in the case of Bophuthatswana: see UK position, Hansard, HC Debs., vol. 105. col. 100 (2 November 1986). 
emerged. ${ }^{328}$ Secondly, in so far as the FRY and, to a lesser extent, Bosnia-Herzegovina and Macedonia were unwilling partners in the dismemberment process, it is difficult to assert that they determined their own status; rather, their independence appears to have been thrust upon them by the fact of dismemberment. It is also apparent that in the view of the Arbitration Commission the principle of effectiveness had only a subordinate role-it being suggested that in virtue of the internationalization of their borders, each of the constituent Republics of the former SFRY enjoyed prima facie statehood irrespective of the effectiveness of their government. Ultimately, the principle of uti possidetis was employed a priori, to protect the integrity of the constitutionally-defined territorial units which were then, and only then, able or entitled to exercise some form of self-determination, whether that be full independence, or integration into a confederation of States. In other words, a principle of boundary delimitation was used as the primary determining tool not only of the shape of the new territorial entities, but also for their international personality as States.

\subsubsection{Internal self-determination}

The Arbitration Commission, perhaps aware of the limits of imposing a strict territorial settlement upon an ethnically diverse population where strong forces of nationalism were at work, sought to mitigate its effect by developing the substance of the internal dimension of self-determination. The first step in its argument was to assert that ' $[w]$ here there are one or more groups within a State constituting one or more ethnic, religious or language communities, they have the right to recognition of their identity under international law'. ${ }^{329}$ Further, the Commission argued that the rights of the minorities so recognized had the status of peremptory norms of international law. ${ }^{330}$ Therefore, the Serbian population in BosniaHerzegovina and Croatia 'must be afforded every right accorded to minorities under international conventions as well as national and international guarantees consistent with the principles of international law and the provisions of Chapter II of the draft Convention of 4 November 1991, which has been accepted by those Republics'. ${ }^{331}$

The position adopted by the Commission in this respect is quite ambitious. Although certain individual rights, and perhaps the right of

\footnotetext{
33* Apart from the Serbian populations in Croatia and Bosnia-Herzegovina, the Republic of Macedonia has a significant Albanian population and Bosnia-Herzegovina has a sizeable Croatian population. Albanians dominate Kosovo and Hungarians, Vojvodina. See generally Rusinow, 'Nationalities and the National Question', in Ramet (ed.), Yugoslavia in the I980's (1985), p. 131. 320 Opinion No. 3, loc. cit. above (n. 5), p. 1498.

330 Ibid., p. 1498. In this matter, the Commission referred back to its first opinion where it had first posited that the rights of minorities had the status of jus cogens.

3.3 Ibid.
} 
self-determination, may have the status of jus cogens, $^{332}$ it has rarely been suggested that the rights of minorities have that status. The ILC, for example, has frequently discussed the possible contenders for the category of norms of jus cogens, but has never even considered that the rights of minorities might be included. ${ }^{333}$ While it is commonly accepted that rules prohibiting slavery, genocide, and perhaps racial discrimination are peremptory norms, it is not easy to extend that reasoning to the whole corpus of human rights. ${ }^{33+}$ Having said that, as a category of human rights, minority rights have a long pedigree dating back to before the creation of the United Nations ${ }^{335}$ and have recently been the subject of considerable attention on the international plane. One may note, in particular, the recent European Framework Convention for the Protection of National Minorities ${ }^{33^{6}}$ and the UN Declaration on the Rights of Persons Belonging to National or Ethnic, Religious, or Linguistic Minorities. ${ }^{337}$ Much as these developments might suggest that the rights of minorities are developing into rules of customary international law, it is undoubtedly too early to suggest that they are now jus cogens norms. Two specific problems may attach to such a proposition. First, in conceiving of minority rights as norms of jus cogens, questions might arise as to the validity of certain individual human rights treaty norms (not having the status of jus cogens) that preserve interests which appear to conflict with those of minority groups. For example, the cultural practices of minority groups may well be incompatible with the right to non-discrimination on the grounds of sex. While much is dependent upon how the essence of the peremptory norm is defined, the differential status of the norms concerned will undoubtedly render more difficult the resolution of any inherent tensions and may ultimately undermine the very integrity of human rights in general.

A second difficulty with the Commission's approach is that although it advised that the Serbian population should be afforded 'every right accorded to minorities under international conventions', at the time of speaking there was no specific human rights convention dedicated to minority rights. The only universal human rights treaty that specifically

33 Above, nn. 286-91.

33 Sec Yearbook of the $I L C$, 1966 , vol. 2, p. 248 .

${ }^{3.3+}$ But see Verdross, 'Yus Dispositivum and jus cogens in International Law', American Journal of International Law, 60 (1966), p. 55, at p. 59.

3.15 See Capororti, 'Study on the Rights of Persons Belonging to Ethnic, Religious and Linguistic Minorities', UN Doc. E/CV.4/Sub.2/1979/384/Rev.1; Thornberry, International Law and the Rights of Minorities ( $199 \mathrm{I}$ ), pp. 25-54. Cf. Minority Schools in Albania, PCIY, Series A/B, No. 64, p. 4 .

13. Intermational Human Rights Reports, 2 (1995), p. 217. This was opened for signature on 1 February 1995 and therefore post-dates the Commission's opinion.

${ }_{3.37}$ GA Resn. 47/135, 8 December 1992, International Legal Materials, 32 (1993), p. 912. 
contained an article referring to minorities was the International Covenant on Civil and Political Rights (Article 27). ${ }^{33^{8}}$ However, the thrust of that article, as with the later Convention and Declaration, is upon the rights of individual members of minority groups rather than upon the rights of the minority per se, the two not being co-terminous.

What is interesting about the Arbitration Commission's approach is that it was not specifically asked to consider the question of minority rights, but rather to spell out the implications of the right to selfdetermination for the Serbian population in Croatia and Bosnia-Herzegovina. That it considered the question of minority rights to be relevant is indicative of its view that there could be some effective assimilation of the concepts. ${ }^{339}$ This it proceeded to make clear later in the same opinion. The Commission referred to common Article I of the two International Covenants on human rights (the International Covenant on Civil and Political Rights ${ }^{340}$ and the International Covenant on Economic, Social and Cultural Rights ${ }^{3+1}$ ) which, in its opinion, establishes that the 'principle of the right to self-determination serves to safeguard human rights'..$^{3+2}$ According to the Commission, by virtue of Article $I$, 'every individual may choose to belong to whatever ethnic, religious or language community he or she wishes'.$^{3+3}$ It continued by asserting that one possible consequence of this principle might be that the Serbian population of Bosnia-Herzegovina and Croatia should have the 'right to choose their nationality'. ${ }^{3+4}$

In general terms, there might be a case for arguing for a more synthetic approach to various categories of human rights (individual rights, group rights and people's rights) by drawing the necessary parallels between them and identifying their common elements. It is clear, for example, that certain minority rights can be framed in individual terms (like Article 27 ICCPR), and that individual rights themselves may be enjoyed on equal terms by members of minorities. Equally, it is apparent that the

\footnotetext{
${ }^{3{ }^{4}}$ Article 27 reads: "In those States in which ethnic, religious or linguistic minorities exist, persons belonging to such minorities shall not be denied the right, in community with the other members of their group, to enjoy their own culture, to profess and practise their own religion, or to use their own language'. See generally Thornberry, op. cit. above (n. 335), pp. 141-247.

330 Cf. Cassese, op. cit. above (n. 287), pp.348-59.

340 UN Treaty Series, vol. 999, p. 171 (1966).

$3+x$ Ibid., vol. 993 , p. 3 (1966).

3+2 Article $\mathrm{I}(1)$ of each Covenant reads: 'All peoples have the right of self-determination. By virtue of that right they freely determine their political status and freely pursue their economic, social and cultural development.' There is no mention here of the function that self-determination has with respect to 'safeguarding' other human rights.

343 Opinion No. 3, loc. cit. above (n. 5), p. 1498. One may wonder at the language employed in this phrase-is there, for example, a difference between the 'right to belong' to a particular community and the 'right to choose to belong' to a particular community?

int Ibid., p. 1499.
} 
internal dimension of self-determination may be reinforced by individual rights, such as the rights to take part in the conduct of public affairs and to vote, and be elected, at genuine periodic elections (Article 25 ICCPR). There are limits to the extent of assimilation, however, which are dictated by the independence and integrity of the rights themselves: the very existence of minority rights and people's rights assumes that the interests they preserve extend beyond those that may be expressed in individual terms. ${ }^{3+5}$

As far as the Arbitration Commission was concerned, it went beyond the traditional understanding of Article $I$ of the Covenants as interpreted by the Human Rights Committee ${ }^{3+6}$ and the Committee on Economic, Social and Cultural Rights, ${ }^{3+7}$ in that it drew from self-determination an individual right, namely, the right to choose to belong to whatever ethnic, religious or language community he or she wishes. It is not clear, however, what was intended by the Commission in this assertion. If it is taken as meaning a right not to be arbitrarily excluded from the benefits of membership in a particular ethnic, religious or language community, it might be acceptable as a general principle ${ }^{3+8}$ If, on the other hand, it entails an unqualified right on the part of an individual to join a community irrespective of the needs or interests of the community itself, it is deeply problematic.

In several cases pertaining to Article 27 ICCPR, the Human Rights Committee has come to consider the problems involved in maintaining a right of individual membership in minority communities. First in the Lovelace case,$^{349}$ and later in the Kitok case, ${ }^{35^{\circ}}$ complainants argued that they had been deprived of their rights under Article 27, namely the right to enjoy their own language or culture in community with other members of their group. In each case, the question related to the existence of legislation aimed at protecting the interests of a minority group which was defined in a way that excluded the individual complainant from enjoying the benefits of membership in that group. The general principle applied by the Human Rights Committee was the same in each case, namely, that 'a restriction upon the right of an individual member

${ }^{3+5}$ Cf. Higgins, op. cit. above (n. 292), pp. 120-1.

${ }^{3+6}$ See McGoldrick, The Human Rights Committee (1991), pp. 247-58; Cassese, 'The SelfDetermination of Peoples', in Henkin (ed.), The International Bill of Rights (1987), p. 92.

${ }^{3+7}$ The CESCR has made remarkably few comments in relation to self-determination. See generally Craven, The International Covenant on Economic, Social and Cultural Rights (1995).

${ }^{3+*}$ Cf. Article 27 ICCPR, above, n. 338.

${ }^{3+9}$ Selected Decisions (1985), p. 83 . See generally Bayefsky, 'The Human Rights Committee and the Case of Sandra Lovelace', Canadian Yearbook of Intemational Law, 20 (1982), p. 244.

${ }^{350}$ HRC Report, General Assembly Official Records, 44th Session, Supplement No, 40, p. 22 I (1989). 
of a minority must be shown to have a reasonable and objective justification and to be necessary for the continued viability and welfare of the minority as a whole'. ${ }^{351}$ In the Lovelace case, the Committee considered the exclusion of a female member of the Maliseet Band from the Tobique Indian Reserve on the basis that she had previously been married to a non-Indian was neither reasonable nor 'necessary to preserve the identity of the tribe' ${ }^{352}$ On the other hand, in the Kitok case, although the Committee did have reservations about the compatibility of certain provisions of the Swedish Reindeer Husbandry Act with Article 27, it did not consider the impediment suffered by the applicant sufficiently grave to outweigh the interests of the minority as a whole as protected by the legislation. ${ }^{353}$ What is clear from both of these cases is that an unqualified right of membership in minority groups is unsustainable if the minority interest is to be maintained intact. Minorities, by their nature, need to have some control over the conditions for membership even if those conditions are subject to other human rights principles such as non-discrimination on the grounds of sex. ${ }^{35+}$ Ultimately, a balance needs to be maintained between the need for a minority to maintain its own identity and the legitimate interests of individual members of that group.

The second principle attributed to the right to self-determination by the Arbitration Commission was that individual members of the minorities in Yugoslavia must be afforded 'the right to choose their nationality'. ${ }^{355}$ Here, the Commission was somewhat more cautious: this, it suggested was merely 'one possible consequence' of recognizing the right of individuals to choose to belong to whatever community they wish, ${ }^{35}$ " and was a principle that should be applied only 'where appropriate'. ${ }^{357}$ The reason for the Commission's caution is plain: not only does it involve the issue of whether there exists a right of expatriation in international law, but it also concerns a prior question as to whether the inhabitants of a territory will succeed to the nationality of the successor State. In general, practice suggests that in cases of State succession, the

15: Ibid., p. 230 , para. 9.8.

$15 \times$ Loc. cit. above (n. 349), p. 87, para. I6.

35.3 It was noted that although the statute restricted reindeer breeding to members of the Sami villages, the applicant (who was not a villager for the purposes of the Act) was nevertheless able to graze and farm his reindeer and to hunt and fish: loc. cit. above (n. 350), para. 9.8.

15. Although the HRC did not consider it necessary to go into the question of non-discrimination in the Loxelace case, it is apparent that one of the major considerations was the fact that the law applied differentially to men and women: see, e.g., individual opinion of Mr Bouriri, loc. cit. above (n. 349), p. 87 .

iss Opinion No. 3, loc. cit. above (n. 5), p. 1499.

15e Ibid., p. 1498.

is 7 Ibid., p. 1499. 
affected population will automatically acquire the nationality of the successor State. ${ }^{358}$ The only substantial difference in opinion is as to whether this occurs ipso jure under the rules of succession ${ }^{359}$ or whether it has merely been general practice as regards a matter which is otherwise exclusively a question for municipal law. ${ }^{360}$ It is considered that even if nationality should be considered primarily a matter within the domestic jurisdiction of the State, that does not preclude the operation of a rule of succession that requires the granting of nationality to residents of the territory concerned provided some genuine connection can be established. ${ }^{36}$ It is particularly clear in the context of Yugoslavia that the territorial settlement would be severely undermined were the Republics to deny nationality to sections of the population on the basis of ethnic origin. In light of that it may be said de lege ferenda that the granting of nationality should not be discriminatory on the basis of racial, religious, ethnic or political grounds. ${ }^{36 z}$ What is more doubtful, however, is whether in cases of succession the affected population have a right of option, ${ }^{363}$ or perhaps a right of expatriation..$^{36+}$ Although there is a certain amount of treaty practice in which a right of option has been provided for ${ }^{365}$ it is perhaps too early to suggest that international law imposes a duty upon the successor State to permit the inhabitants of the territory to opt for an alternative nationality..$^{36 t}$ Nevertheless, this principle may well be suited to the specific context of the Yugoslav situation in which a number of the minorities have ethnic affiliations with one of the other Republics or neighbouring States.

${ }^{35 *}$ Sce generally Weis, Nationality and Statelessness in Intermational Law (1956); Brownlie, op. cit. above (n. 38), pp. $555^{-9}$.

(s.) See Brownlic, who comments:

'Sovercignty denotes responsibility, and a change of sovereignty does not give the new sovereign the right to dispose of the population concerned at the discretion of the government. 'Ihe population goes with the territory: on the one hand, it would be illegal, and a derogation from the grant, for the transferor to try to retain the population as its own nationals, and, on the other hand, it would be illegal for the successor to take any steps which involved attempts to avoid responsibility for conditions on the territory, for example, by treating the population as de facto stateless or by failing to maintain order in the area': op. cit. abose (n. 38 ), p. 664 .

sho In the Nationality Decrees in Tunis and Morocco case, PCIJ, Series B, No. 4, p. 24 (1923), it Was stated that 'in the present state of international law, questions of nationality are . . in principle within the reserved domain' of a State's domestic jurisdiction. See also O'Connell, op. cit. above (n. 125), vol. 2, pp. 497-506; Weis, op. cit. above (n. 358), p. 149; Jones, British Nationality Law (1956), pp. 20-6; Oppenheim, op. cit. above (n. 121), p. 219.

it Cf. Nottebohm case (Liechtenstein v. Guatemala), ICY Reports, 1955, p. 4.

${ }^{3 / 2}$ Cf. UN Convention on Reduction of Statelessness, 1961, Article 9.

${ }_{3 \text { th }}$ Sec Kaufmann, 'Règles générales du droit de la paix', Recueil des cours, 54 (1935-IV), p. 373 .

int Article 15 UDHR provides that "No one shall be arbitrarily deprived of his nationality nor denied the right to change his nationality". 'The ICCPR provides somewhat less directly for a right to liberty of movement and freedom to choose one's residence, and a right to leave any country, including one's own (Article 12 ).

3ts e.g. Brest-Litowsk, I918. For practice until 1918, see Kunz, 'L'Option de Nationalité', Recueil des cours, 3 I (1930-1), p. 112.

sot Sec generally $O^{\prime}$ Connell, op. cit. above (n. 125 ), pp. 529-36. 


\subsection{Succession of States}

The majority of the Arbitration Commission's opinions related in some manner at least to the question of succession. As noted above, the approach adopted by the Commission in its first opinion essentially established the framework for all its subsequent opinions. This is particularly true with respect to the question of succession. The Arbitration Commission initially outlined the broad principles upon which problems of succession should be solved in its ninth opinion. Following that, the Co-Chairmen of the Steering Committee of the ICFY submitted a further six questions to the Arbitration Commission on 20 April 1993 which were addressed in Opinions $11-15 .^{367}$ It is beyond the scope of this article to address all the issues raised in the depth necessitated by a complex and difficult area of law, and for that reason, the general elements of the Commission's approach will be outlined and a number of issues selected for discussion. It is notable to begin with that the Commission was only called upon to address directly questions of succession to State property, archives and debts. In consequence, the issues of succession to membership in international organizations ${ }^{36 \mathrm{~B}}$ and

$3_{77}$ The six questions were as follow's:

'1) In light of the inventory in the report by the Chairman of the Working Group on Economic Issues, what assets and liabilities should be divided between the successor States to the former Socialist Federal Republic of Yugoslavia during the succession process?

2) On what date(s) did succession of States occur for the various States that have emerged from the Socialist Federal Republic of Yugoslavia?

3a) What legal principles apply to the division of State property, archives and debts of the Socialist Federal Republic of Yugoslavia in connection with the succession of States when one or more of the parties concerned refuse(s) to cooperate?

b) In particular, what should happen to property

- not located on the territory of any of the States concerned, or

- situated on the territory of the States taking part in the negotiations?

4) Under the legal principles that apply, might any amounts owed by one or more parties in the form of war damages affect the distribution of State property, archives and debts in connection with the succession process?

5a) In view of the dissolution of the Socialist Federal Republic of Yugoslavia, is the National Bank of Yugoslavia entitled to take decisions affecting property, rights and interests that should be divided between the successor States to the Socialist Federal Republic of Yugoslavia in connection with the succession of States?

b) Have the central banks of the States emerging from the dissolution of the Socialist Federal Republic of Yugoslavia succeeded to the rights and obligations of the National Bank of Yugoslavia deriving from international agreements concluded by the latter, in particular the 1988 Financial Agreement with foreign commercial banks?

6a) On what conditions can States, within whose jurisdiction property formerly belonging to the Socialist Federal Republic of Yugoslavia is situated, oppose the free disposal of that property or take other protective measures?

b) On what conditions and under what circumstances would such States be required to take such steps?' (International Legal Materials, 32 (1993), p. 1580 ).

${ }^{368}$ See generally Blum, loc. cit. above (n. 244); Lloyd, loc. cit. above (n. 244); Williams, 'State Succession and the International Financial Institutions: Political Criteria v. Protection of Outstanding Financial Obligations', International and Comparative Law Quarterly, 43 (1994), p. 776. 
succession to treaties (especially human rights treaties), ${ }^{369}$ although raising a number of interesting questions in the context, will not be considered here.

\subsubsection{The Vienna Conventions}

Throughout its opinions on succession, the Commission took as its starting point the 'principles of international law embodied in the Vienna Conventions of 23 August 1978 and 8 April r983'.370 The two Vienna Conventions were drafted as a result of the perceived lack of consistency in State practice and in particular the fear that such practice as existed gave 'undue prominence to the interests of the major imperial powers and not enough to those of the newer members of the international community'.37' The initial drafts of the Conventions were compiled by the International Law Commission in $1974^{372}$ and $1981,{ }^{373}$ the final text being completed at two conferences held in Vienna in 1977 and 1983 . It is clear, however, that neither Convention has acquired the I 5 ratifications or accessions necessary for them to enter into force and there is no prospect of their doing so in the near future. In that respect, one might question the Arbitration Commission's reliance upon the principles embodied therein.

Two factors might go to explain the position of the Commission on this point. The first, rather weak, justification is that the SFRY was one of the few States at that time to have ratified the two Vienna Conventions. It is abundantly clear, however, that the SFRY was not strictly bound by the terms of the Conventions before their entry into force, ${ }^{37+}$ and that even then, their application in the present situation was dependent either upon their having passed to the succeeding States in virtue of the rules of succession which they embody, or by reason of their embodying operative rules of customary international law. Secondly, and somewhat more significantly, all the Republics had agreed that the

$3^{\text {tho }}$ On this point see Shaw, 'State Succession Revisited', Finnish Yearbook of International Law, 6 (1995), p. 34; Mullerson, "The Continuity and Succession of States by reference to the Former USSR and Yugoslavia', International and Comparative Law Quarterly', 42 (1993), p. 473; id., 'Vew' Developments in the Former USSR and Yugoslavia', Virginia Journal of International Law, 33 (1993), p. 299; Williams, 'The Treaty Obligations of the Successor States of the Former Soviet Union, Yugoslavia and Czechoslovakia: Do they Continue?", Dencer Fournal of Imternational Laze and Policy, 23 (1994), p. I; Schachter, 'State Succession: The Once and Future Law', Virginia Journal of International Law, 33 (1993), p. 253; Williamson and Osborn, 'A US Perspective on Treaty Succession and Related Issues in the Wake of the Breakup of the USSR and Yugoslavia', ibid., p. 261 ; Martins, 'An Alternative Approach to the International Law of State Succession', Syracuse Law Review, 44 (1993), p. rorg.

370 Vienna Convention on Succession of States in respect of Treaties, 1978, American fournal of International Law, 72 (1978), p. 971; Vienna Convention on Succession of States in respect of State Property, Archives and Debts, 1983 , Intermational Legal Materials, 22 (1983), p. 306.

371 Oppenheim, op. cit. above (n. 121 ), p. 236.

"7x Yearbook of the $I L C, 1974$, vol. 2, part 1, p. 174.

37.1 lbid., 1981 , vol. 2, part 2, p. 20.

$37+$ Cf. Article 18 of the Vienna Convention on the Law of Treaties, 1969, UN Treaty Series, vol. 1155 , p. 331 . 
Conventions should form the 'foundation for discussions between them on the succession of states at the Conference for Peace in Yugoslavia' ${ }^{375}$ Whilst this falls considerably short of an agreement to be bound by the terms of the Conventions, it is entirely appropriate for the Conventions then to be used by the Arbitration Commission as the starting point for its consideration of the issues.

It is interesting to note that the Commission's appreciation of the precise status of the rules embodied by the Vienna Conventions appears to change through its opinions. In its first opinion it speaks of the Conventions having 'drawn inspiration' from the general principles of international law. ${ }^{376}$ Later, in its eighth and ninth opinions, it refers to the general principles that are embodied in the Conventions, but stops short of defining the provisions to which it refers. ${ }^{377}$ By the time it came to deliver its thirteenth opinion in July 1993, the Commission clearly took a more circumspect view. There, it noted that 'there are few wellestablished principles of international law that apply to State succession' and that application of those principles is largely to be determined case by case, depending on the circumstances proper to each form of succession'. In that respect, it suggested, rather lamely, that the Vienna Conventions 'do offer some guidance' ${ }^{378}$ It is undoubtedly the case that some provisions of the Vienna Conventions do reflect customary international law: one might suggest, inter alia, Articles I I, I $5(a), 16,24(\mathrm{I})$ of the 1978 Convention and Articles 12, 14(2)(a), 15(1)(a), 17(1)(a) and $18(\mathrm{I})(\mathrm{d})$ of the 1983 Convention. ${ }^{379}$ On the other hand a number of provisions, and especially those relating to 'newly independent States', ${ }^{380}$ do not draw upon established State practice and are therefore more in the nature of norms aimed at the progressive development of international law. ${ }^{381}$ What was perhaps overlooked by the Arbitration Commission in its reliance upon the Vienna Conventions was their limited scope. There are undoubtedly a number of questions that might arise in the context of succession on which the Vienna Conventions have nothing to say. It is clear, for example, that the Vienna Convention of 1983 does not deal with State debts owed to private individuals as distinct from other States, nor with questions or nationality, currency, or criminal, as opposed to

373 Opinion No. 8, loc. cit. above (n. 5), p. 1524.

$37^{6}$ Opinion No. 1, loc. cit. above (n. 5), p. 1495.

377 Opinion No. 8, loc. cit. above (n. 5), p. 1523; Opinion No. 9, loc. cit. above (n. 5), p. 1525

${ }_{378}$ Opinion No. 13, loc. cit. above (n. 8), p. 1592.

379 These are no more than examples-there are clearly a number of other provisions about which there would be little disagreement.

${ }^{380}$ e.g. Articles 15, 28, 38, Vienna Convention, 1983 .

${ }^{\mathrm{B}} \mathrm{H}$. The preambles of both Conventions refer to the need for the codification and progressive development of the rules relating to succession of States' (emphasis added). It was clearly acknowledged by members of the ILC that their role in drafting the Vienna Conventions was more legislative than codificatory: see Ago, Yearbook of the ILC, 1973, vol. 1, pp. 101-2. 
contractual, responsibility. ${ }^{382}$ One may only assume that the Commission considered that the broad principles it outlined would be equally operative in these areas.

\subsubsection{Broad principles}

The Commission dealt with the broad principles on which the succession of the various Republics should be based initially in its ninth opinion. ${ }^{8_{3}}$ There, it had been asked to outline 'on what basis and by what means should the problems of the succession of states arising between the different states emerging from the SFRY be settled'. According to the Commission, ' $\mathrm{t}$ ] $\mathrm{he}$ chief concern is that the solution adopted should lead to an equitable outcome, with the states concerned agreeing procedures subject to compliance with the imperatives of general international law and, more particularly, the fundamental rights of the individual and of peoples and minorities' ${ }^{3{ }^{8}+}$ From this rather brief statement of principle, the Commission then outlined a number of more detailed conclusions. The two main elements of its opinion were that, first, the successor States (of whom none could claim to be the sole successor) should settle all aspects of succession by agreement. ${ }^{3_{5}}$ Failing agreement, they must settle all disputes peacefully, 'in line with the principle laid down in the United Nations Charter' and in particular by means of inquiry, mediation, conciliation, arbitration or judicial settlement. ${ }^{386}$ Secondly, the successor States should try to achieve an equitable solution by drawing on the principles in the Vienna Conventions and general international law, taking into account the principle of equality of rights and duties between States. ${ }^{3{ }^{37}}$ It noted, in particular, that the assets and debts of the SFRY, together with its property located in third countries, must be divided equitably between the successor States. ${ }^{3 \mathrm{x}}$

\subsubsection{The obligation to negotiate, non-cooperation, and third States}

In its twelfth opinion, ${ }^{34}$ the Commission came to address an issue which had primarily arisen from the non-participation of the FRY in the Conference Working Group on Succession which was attempting to deal with the complex issues of dividing assets and debts. It was asked, in particular, to outline what principles were to apply to the division of State property, archives and debts in the face of a State's refusal to

\footnotetext{
${ }_{3} \mathrm{~K}_{2}$ The carlier title of the Vienna Convention of 1983 referred broadly to 'matters other than treaties'; this was changed in recognition of the narrow scope of the Convention: ibid., $198 \mathrm{r}$, vol. 2 , p. 21 .

${ }^{33_{3}}$ Opinion No. 9, loc. cit. above (n. 5), p. 1523.

$3^{x_{*}}$ Ibid.

${ }_{3} \mathbf{s}_{\mathrm{s}}$ Ibid.

${ }_{3 \mathrm{kt}}$ Ibid., p. 1525. Cf. Article 33, UN Charter.

${ }^{\text {N }} 7$ Ibid.

${ }^{3 \mathrm{kK}}$ Ibid.

3ky Opinion No. 12, loc. cit, above (n. 8).
} 
co-operate, and what protective measures could, and should, be taken by the remaining States. ${ }^{390}$

In response to the questions, the Commission reiterated its broad position that it was for the States concerned to achieve an equitable result by negotiation and agreement inter se. If a State refused to co-operate to that end, it would be in breach of that obligation and would be liable internationally for any loss suffered as a result. In such a case, the Commission considered that it would be open to those States sustaining such a loss to take non-forcible counter-measures in accordance with international law'. ${ }^{39}$ ' It added, however, that the fact of non-cooperation does not relieve the other States of their obligation to consult with each other to achieve a comprehensive equitable result whilst reserving the rights of the non-cooperating State(s). Any agreement arrived at by the remaining parties is res inter alios acta in relation to all third parties ${ }^{342}$ (including both third States upon which property of the SFRY is located and non-cooperating States), which are therefore not bound by its terms unless they specifically consent to be so bound. Finally, the Commission noted that third States may take such interim measures as may be necessary to safeguard interests of the successor States and that they would be under an obligation to do so if a competent international agency had so declared. ${ }^{3 \% 3}$

It is generally appreciated that the allocation of assets and debts among successor States should ideally be achieved by agreement among the parties concerned, and that the rules embodied in the Vienna Convention are generally operable only where no such agreement has been reached. It is less clear, however, whether it can be said that there is in fact an obligation to negotiate. The fact that in many cases States have resorted to negotiation to settle questions of succession ${ }^{30+}$ does not in itself provide evidence of any necessary obligation in that regard. It might be said, nevertheless, that such an obligation might flow from the fact that the issues involved relate not only to the rights and duties of successor States, but also to those of third parties, and that negotiation is a sine qua non for the equitable resolution to the problems. It is pertinent to note, as the Commission made clear, that even if a State should choose not to co-operate in the division of assets and liabilities, it would not lose the interest it had over the property concerned; it would merely be internationally liable for any loss incurred from its non-cooperation.

As regards its remarks on counter-measures, the Arbitration Commission was undoubtedly correct in asserting initially that States sustaining

300 Ibid., pp. $1589-90$.

191 Ibid., p. 1590.

342 Ibid. Cf. Article 34, Vienna Convention on the Law of Treaties.

19.. Ibid., p. 1591.

${ }^{304}$ e.g., Agreement on partition of debt of Czechoslovakia, 1939; Agreement on distribution of debt of Yugoslavia, 1941; sec O'Connell, op. cit. above (n. 125), vol. 2, pp. $389-90$. 
loss would be entitled to take non-forcible measures. In stressing that counter-measures could be taken 'in accordance with international law', it appears that the Commission had in mind the requirement that they be essentially 'proportionate' to the loss suffered and should be aimed at the restoration of equality between the parties. ${ }^{395}$ Although there might be some difficulty in determining the nature of the loss involved in absence of an agreement to that effect, the States affected are entitled to take some otherwise illegal measures to induce the non-cooperating party to return to negotiations. ${ }^{306}$

The Arbitration Commission appears to state this principle in too broad a manner, however, when it refers to the right of third States to take interim measures of protection in order to protect the interests of the successor States. ${ }^{397}$ As Pellet notes, this appears to give recognition to a form of 'collective counter-measures' that would only be conceivable in relation to obligations erga omnes. ${ }^{398}$ In essence, it is only those States that have suffered loss as a result of an illegal act by another State that are competent under international law to take counter-measures. In the circumstances, this might be the case with respect to third States which possess a financial interest in the property that has yet to be divided among the successor States. Third States, upon whose territory property relating to the succession of States is located, would not by that account suffer loss, and as such would not be entitled to take counter-measures. But in so far as they possessed an interest in the general settlement they might thereby be entitled to take retorsionary measures. This, however, falls considerably short of the 'interim measures of protection' envisaged by the Arbitration Commission.

\subsubsection{The division of assets and liabilities}

In its fourteenth opinion, ${ }^{3 \%}$ the Arbitration Commission was asked to indicate, in light of the inventory that had been drafted by the Working Group on Economic Issues, what assets and liabilities should be divided between the successor States to the SFRY. It is quite understandable that, in light of the continuing negotiations and the highly complex nature of the issues involved, the Arbitration Commission confined itself to stating the broad principles that were to apply. It noted first that the Working Group had divided the items on the inventory into two sections: agreed terms and non-agreed items. ${ }^{+\infty}$ With respect to the

\footnotetext{
195 Air Serices Agreement case (1978), Reports of International Arbitral Awards, vol. I8, p. 416. It might also be suggested that counter-measures are illegitimate in cases where procedures for peaceful settlement have already been agreed: Yearbook of the ILC, 1979, vol. 2, part 2, p. 118.

${ }_{306}$ Cf. Article 30, ILC Draft Articles on State Responsibility, Yearbook of the ILC, 1980, vol. 2, part 2, p. 33.

(1n) See, Pellet, loc. cit. above (n. 19) (1993), pp. 298-9.

sq* Ibid.

30" Opinion No. 14, loc. cit. above (n. 8).

too Ibid., p. 1593 .
} 
former, the Commission considered that they should be divided between the successor States. As regards the non-agreed items, the Arbitration Commission felt that it did not have sufficient information on which to base a decision and that in any case, it was not the type of issue it could readily resolve in its capacity as a consultative body. ${ }^{+01}$ It therefore resolved to confine itself to 'determining the general principles to be applied'.

The Commission proceeded to outline the applicable principle as follows:

3. The Commission would nevertheless draw attention to the well-established rule of state succession law that immovable property situated on the territory of a successor State passes exclusively to that State. Subject to possible compensation if such property is divided very unequally between the successor States to the SFRY, the principle of the locus in quo implies that there is no need to determine the previous owner of the property: public property passes to the successor State on whose territory it is situated. The origin or initial financing of the property and any loans or contributions made in respect of it have no bearing on the matter.

4. As regards other State property, debts and archives, a commonly agreed principle to be found in several provisions of the Vienna Convention of 8 April 1983 on the Succession of States in Respect of State Property, Archives and Debts requires that they be divided between the successor States to the SFRY if, at the date of succession, they belonged to the SFRY, and the question of the origin and initial financing of the property, debts and archives, or of any loans or contributions made in respect of them, is irrelevant.

5. To determine whether the property, debts and archives belonged to the SFRY, reference should be had to the domestic law of the SFRY in operation at the date of succession-notably to the 1974 Constitution..$^{402}$

The first point to be made here is that the Commission did not explicitly determine how the property, archives and debts should be divided, but rather confined itself to identifying which pieces of property should be so divided. ${ }^{+03}$ In doing so, it clearly excluded from division immovable public property situated in the territory of the successor State. That such property should in principle pass to the successor State upon whose territory it is located appears an inevitable conclusion and may as such be considered to be declaratory of customary international law. ${ }^{+0+}$ Rather

401 Ibid., p. 1594.

402 Ibid., p. 1594.

40.3 The ILC notes: 'the basic principle may be stated that in general, State property passes from the predecessor State to the successor State. It is through the application of a material criterion, namely, the relation which exists between the territory and the property by reason of the nature of the property or where it is situated, that the principle of the passing of State property can be deduced': Yearbook of the $1 L C, 198 \mathrm{r}$, vol. 2, part 2, p. 29.

10. Treaty between Netherlands and Belgium, 1839, Art. 15; Agreement between Pakistan and India, 1947. See also Articles 14, 15(1)(a), 16, 17, 18, Vienna Convention, 1983; Yearbook of the ILC, 1981, vol. 2, part 2, pp. 33-6; O'Connell, op. cit. above (n. 125), vol. 1, pp. 199-200, 204, 220 . 
more controversially, the Arbitration Commission proceeds to suggest that the principle of the locus in quo can be applied to all public property found on the State in question; in other words that any movable property found on a successor State's territory would automatically pass to that State. Here the Commission departs somewhat from the terms of the Vienna Convention, which provides that only 'movable State property of the predecessor State connected with the activity of the predecessor State in respect of the territory to which the succession of States applies shall pass to the successor State'. ${ }^{+05}$ What appears to be the main thrust of the Convention qualification is that property only accidentally located on the territory of a particular State should not pass to that State, but rather should move to the State with whose territory the property has some connection. ${ }^{+06}$ In that sense, the Arbitration Commission's rule would appear too broad. However, from a pragmatic point of view, given the problems that might be associated with defining what property is 'connected with the activity of the predecessor State', ${ }^{+07}$ the approach adopted by the Arbitration Commission, with the qualification that compensation may be payable if the rule results in the very unequal (or perhaps inequitable) division of property, would appear to be a more workable approach.

With respect to all other property (property, whether movable or immovable, located in territory abroad), debts, and archives, the Arbitration Commission determined that they should be divided among the successor States, but gave little indication as to the principles that should govern their division. All that it suggested was that the division should be broadly equitable and should not take into account the origin or initial financing of the property, debts, archives or any loans or contributions made in respect of them.

As regards the principle of equitable apportionment, ${ }^{+0 *}$ which clearly draws upon the notion of equity as employed in the context of maritime delimitation, ${ }^{+09}$ the Commission noted that Articles 18,31 and 41 of the Vienna Convention 'do not require that each category of assets or

+os See Article 17, also Articles $14(2)(b)$, I $5(1)(d), 18(1)(c)$. O'Connell defines the principle in the following manner: "only such property as is destined specifically for local use is acquired by the successor State': op. cit. above (n. 121), vol. 1, p. 204.

4on The ILC stated in its commentary that 'the mere fact that movable State property is situated in the territory to which the succession of States relates should not automatically entitle the successor State to claim such property': Yearbook of the ILC, 1981, vol. 2, part 2, p. 29. Cf. Oppenheim, op. cit. above (n. 121), p. 220, n. 7 .

to7 Problems would clearly arise with respect to items such as railway rolling-stock, other forms of public transport and military supplies.

tos Crawford notes that this concept may owe something to the notion of 'unjust enrichment' utilized by $O^{\prime}$ Connell: Crawford, loc. cit. above (n. I36), p. 46.

too 'The ILC explicitly drew upon the notion of equity as an "autonomous source of law". It referred in that context to the North Sea Continental Shelf cases, ICY Reports, 1969, p. 3, where it was stated that 'it is not a question of applying equity simply as a matter of abstract justice, but of applying a rule of law which itself requires the application of equitable principles': Yearbook of the $I L C$, $198 \mathrm{I}$, vol. 2 , part 2, p. 20 
liabilities be divided in equitable proportions but only that the overall outcome be an equitable division' ${ }^{410}$ There is some evidence from State practice that in cases of dismemberment, public property held abroad should be divided proportionately among the successors, ${ }^{41}$ as should the public debt. ${ }^{42}$ There is less evidence from practice that this should be strictly 'equitable'. As the ILC noted: '[e]quity cannot be assigned the main role, because there is also a material criterion concerning the connection between the property and the activity of the predecessor State in the territory. In fact, the principle of equity is more a balancing element, a correlative factor designed to preserve the "reasonableness" of the linkage between the movable State property and the territory.' +13 With respect to State archives, for example, the position is complex in so far as some archives will have especial relevance to a particular portion of territory or its administration, while others will retain their historical and cultural validity only by being maintained intact. As such, the 'equitable apportionment' principle could only be applied in a very general manner. ${ }^{+1+}$ Ultimately, while the 'equitable apportionment' principle would appear to be broadly sound, there is a need to establish the denominators that influence the application of equity in a particular context. ${ }^{415}$ In the apportionment of debt, for example, the relevant considerations might be the proportion of territory or population taken up by each State, the capacity to honour the debts, ${ }^{4+6}$ or even the extent to which the successor had already contributed to the debt. ${ }^{+17}$

Nevertheless, in the division of property, debts or archives, it would appear to be the case, as the Arbitration Commission asserts, that their origin and financing are broadly irrelevant. ${ }^{+18}$ The one exception pro-

\footnotetext{
to Opinion No. 13, loc. cit. above (n. 8), p. 1592. Cf. North Sea Continental Shelf cases, ICJ Reports, 1969, p. 3, where it was stated that '[e]quity does not necessarily imply equality'.

+11 e.g., division of diplomatic property abroad on dissolution of the Federation of Rhodesia and Nyasaland, 1963: O'Connell, op. cit. above (n. 12), vol. 1, p. 231; Yearbook of the ILC, 1981, vol. 2, part 2, pp. 46-7.

112 e.g., dissolution of Union of Colombia, 1829 ; dismemberment of Yugoslavia, 1941 ; dissolution of Federation of Rhodesia and Nyasaland, 1963: O'Connell, op. cit. above, (n. 121), vol. 1, pp. 388-94. Also dismemberment of Austria-Hungary, Treaty of St Germain, Art. 203. The key to apportionment is unclear and appears to have varied in each case. See generally Feilchenfeld, op. cit. above (n. 133), pp. 205-7, 219-599; Yearbook of the ILC, 1981, vol. 2, part 2, pp. 72-113.

413 Yearbook of the ILC, 1981 , vol, 2, part 2, p. 19.

${ }^{414}$ Cf. State practice in Yearbook of the ILC, 3981 , vol. 2, part 2, pp. 68-71.

1' Cf. dissenting opinion of Judge Gross in the Gulf of Maine case, ICY Reports, p. 246, at p. 386 .

+16 This was considered to be a particularly important factor in debt apportionment, but was excluded from the text of the draft Convention for fear that it might be considered the only relevant consideration: Yearbook of the ILC, 1981, vol. 2, part 2, p. 113 .

417 Cf. Article $14(1)(f)$, Vienna Convention.

4* Some State practice does point to the relevance of financing, however: see Agreement between Norway and Sweden, 1906, Article 6, cited in Yearbook of the ILC, 1981, vol. 2, part 2, p. 46. Cf. dispute over the application of principles of locus in quo or financial contribution in case concerning Cession of Vessels and Tugs for Navigation on the Danube (1921), Reports of International Arbitral Awards, vol. 1, pp. 97-212.
} 
vided by the Vienna Convention of $\mathrm{r}_{983}$ is that in the case of 'Newly Independent States' both movable and immovable property situated outside the territory of the State 'shall pass to the successor State in proportion to the contribution of the dependent territory' ${ }^{+19}$ It is clear, however, that this is a controversial provision and that in any case the former Yugoslav Republics do not fall within the category of 'Newly Independent States' as defined by the Convention. ${ }^{+20}$

The Arbitration Commission was faced with two problems in this context that related to the particular characteristics of the SFRY. The first, arising from the federal structure of the Yugoslav State, was that the 1974 Constitution transferred to the constituent Republics ownership of many items of property. These items of property, according to the Arbitration Commission, cannot be held to have belonged to the SFRY 'whatever their origin or initial financing'. ${ }^{21}$ What is confusing about the Arbitration Commission's position on this point is that it either appears to distinguish between public property held by the Federation and public property held by the various Republics; or it assumes that once property is handed over to the Republics it becomes private property for the purposes of succession. ${ }^{+2 z}$ Neither position appears particularly satisfactory: the first option assumes that despite the dismemberment of the SFRY, there was some de jure continuity of sovereignty at a regional level; the second option distorts reality by suggesting that the various Republics were essentially non-governmental or private entities during the life of the Federation. What the Arbitration Commission clearly had in mind was the fact that if property could be clearly attributed to a particular piece of territory, it should presumptively pass to the State which assumes responsibility for that territory. As such, it might have been better for the Commission to suggest that such property would pass to the successors by virtue of the locus in quo principle, rather than to exclude it a priori.

The second problem confronting the Arbitration Commission was that the SFRY had possessed a 'particularly highly developed' concept of 'social ownership' in which certain items of what might be considered 'public' property, debts and archives were held by 'associated labour organizations'- bodies with their own legal personality. With respect to those organizations that operated exclusively within the jurisdiction of one Republic, the Commission took a territorial approach in asserting that 'their property, debts and archives are not to be divided for the

40 Article 15.

${ }^{20}$ Article 2(1)(e) defines 'newly independent States' as successor States 'the territory of which immediately before the date of the succession of States was a dependent territory for the international relations of which the predecessor State was responsible '. See Yearbook of the ILC, 1974, vol. 2, pp. $175^{-6}$.

+31 Opinion No. 14, loc. cit. above (n. 8), p. 1594.

${ }^{422} \mathrm{Cf}$. the distinction between State debt, local debt, and localized debt: see Yearbook of the ILC, 1981, vol. 2, part 2, pp. 74-5; O'Connell, op. cit. above (n. 121), vol. 1, pp. $416 \mathrm{ff}$. 
purposes of state succession: each successor state exercises its sovereign powers in respect of them' ${ }^{423}$ In relation to those organizations that operated 'social ownership' at a federal level, or in two or more republics, the position was a little more complex. The Commission determined that where the organizations "exercised public prerogatives on behalf of the SFRY or of individual republics' their property, debts and archives should be divided between the successors. ${ }^{+2+}$ On the other hand, 'organizations operating at a federal level or in two or more republics but not exercising such prerogatives should be considered private-sector enterprises to which state succession does not apply'..$^{425}$

Essentially, this was a classic example in which resort to the municipal law of the predecessor State failed to clarify for the purposes of succession whether the property in question was either public or private. ${ }^{+26}$ The Arbitration Commission resorted therefore to a functional division in which the test was whether or not the organization concerned exercised 'public prerogatives' on behalf of the SFRY or individual republics. This test appears to be an appropriate and pragmatic response to a question which cannot easily be resolved by resort to rules of universal application. ${ }^{+27}$

The Arbitration Commission came to address a similar problem in its fifteenth opinion in which it was asked to consider, first, whether the National Bank of Yugoslavia (NBY) was entitled to take decisions relating to property, rights and interests that should be divided among the successor States; and secondly, whether the central banks of the successor States succeeded to the rights and obligations of the NBY deriving from international agreements with the latter ${ }^{428}$ The Commission began by noting that '[a]lthough municipal laws are merely facts in international law (Certain German Interests in Polish Upper Silesia, 1926 PCIJ, Ser. A, No. 7, 12), account must nevertheless be taken of the structure and responsibilities of the NBY as set out in the SFRY Constitution of 21 February 1974 and in the NBY Statute of November $1989^{\prime} .^{+29}$ It then confirmed that '[a]s the bank of issue of the SFRY, the NBY participated in the exercise of the prerogatives of sovereignty' and was responsible for carrying out common currency issue, credit and foreign exchange policy as a 'composite of banking institutions'. As the NBY 'partook of the State power of the SFRY', and as its collective

423 Opinion No. 14, loc. cit. above (n. 8), p. 1594.

424 Ibid.

425 Ibid., p. 1595.

${ }^{426}$ Cf. Article 8, Vienna Convention, 1983.

27 Cf. Peter Pázmány University case, PCIJ, Series A/B, No. 61, p. 237. It should be noted that many treaties specifically provide definitions of State property, e.g. Annexes to Treaty of 1960 establishing the Republic of Cyprus. Cf. also GA Resn. 388(V), 15 December $195^{\circ}$ (in respect of Libya); GA Resn. 530 (VI), 29 January 1952 (in respect of Eritrea).

424 Opinion No. 15. loc. cit. above (n. 8), pp. 1595-6.

+29 Ibid., p. 1596. 
structure subsequently disintegrated with the SFRY, none of its organs 'can take legitimate decisions in respect of property, rights and interests that should be divided between the successor States of SFRY'. The Arbitration Commission added that the only legitimate role for the NBY in such circumstances would be as a 'coordinating agency' acting on behalf of the central banks of the successor States for the purposes of 'jurisdictio inter volens to effect-rather than obstruct-the division of the property, rights and interests of the former SFRY'.

As regards the second question, the Arbitration Commission distinguished between those rights and obligations that attach to the NBY as an organ of the SFRY, and those which it has assumed 'acting as a bank with its own legal personality'. The former are subject to State succession but 'do not pass automatically to the central banks of the States emerging from the dissolution of the SFRY' in that 'it is for each of the successor States to determine, by virtue of its sovereign constitutional powers, how these rights are to be exercised and these obligations discharged'. On this point, the Arbitration Commission clearly had in mind the doctrine of 'acquired rights' that underlies the notion of succession in the Vienna Convention, ${ }^{+30}$ namely that rights and obligations are not 'inherited' as in municipal law, but rather that the interests they embody are 'acquired' in virtue of the succession. As the Vienna Convention points out, " $[t]$ he passing of State debts entails the extinction of the obligations of the predecessor State and the arising of the obligations of the successor State in respect of the State debts which pass to the successor State' ${ }^{+3 '}$ 'Accordingly, debts, property, and archives, are 'transferred' to, or 'assumed' by, the successor State, which merely inherits a state of fact over which it, or another party, has an equitable interest. ${ }^{432}$ As the ILC explained:

Succession of States in respect of State debts can create a relationship between the predecessor State and the successor State with regard to debts which linked the former to the third State, but . . . it cannot, in itself, establish any direct legal relationship between the creditor third State and the successor State, should the latter 'assume' the debt of the predecessor. ${ }^{433}$

It follows that although the third parties retain their legal interest in the property formerly held by the NBY, they cannot enforce that interest vis$\grave{a}$-vis the successor States in virtue of the original agreement. ${ }^{+3+} \mathrm{By}$ the same token the successor States, while not 'inheriting' any rights and obligations under the original agreement, are obliged under international

\footnotetext{
${ }^{+30}$ The question of 'acquired rights' was particularly controversial in the work of the ILC: see Yearbook of the ILC, 1969, vol. 2, p. 69.

43 Vienna Convention, 1983 . Article 34 . Cf. also Articles 9 and 21.

t12 O'Connell, op. cit. above (n. 121), vol. 1, pp. $237-9$.

+1. Yearbook of the $I L C, 1981$, vol. 2, part 2, p. 81 .

$\$ 1+$ Ibid., p. 83 .
} 
law to discharge any obligations owed to third parties to which they have succeeded.

As regards the ordinary commitments undertaken by the NBY 'acting as a bank with its own legal personality', the Arbitration Commission offered no direct opinion-it merely asserted that any such rights and obligations do not pass to the successor State. The matter is also left open by the Vienna Convention of 1983 , which specifically provides that nothing in the Convention should be considered 'as prejudging in any respect any questions relating to the rights and obligations of natural or juridical persons'. ${ }^{435}$ The position adopted by the Arbitration Commission may be interpreted in two ways: either that private rights and obligations became bona vacantia with the extinction of the SFRY, or that they remained intact, entirely unaffected by the change in sovereignty. It has to be assumed, given the palpable need for stability and certainty in legal relations, that the Arbitration Commission considered the second interpretation to be the case.

\subsubsection{War damages}

In one of the more straightforward questions, the Commission was asked whether any amounts owed by one or more parties in the form of war damages should affect the distribution of State property, archives and debts in connection with the succession process. ${ }^{436}$ The Commission began by pointing out that the rules applicable to State succession were distinct from those relating to State responsibility. ${ }^{+37}$ Accordingly, the division of assets and liabilities of the SFRY must be effected without the question of war damages being allowed to interfere in the matter of State succession. However, it admitted that 'the possibility cannot be excluded ... of setting off assets and liabilities to be transferred under the rules of State succession on the one hand against war damages on the other'. ${ }^{+38}$

In essence the Commission was probably correct in suggesting that in the equitable apportionment of the assets and liabilities of the SFRY, it would not be appropriate to bring into account the question of responsibility of one Republic vis-à-vis another. It might well be asked, however, whether it is correct to distinguish categorically between the principles relating to State succession and those of State responsibility. In that respect one might recall the definition adopted by the Arbitration Commission in its first opinion, namely that succession entails the 'replacement of one State by another in the responsibility for the international relations of territory' (emphasis added). ${ }^{+39}$ On one view at least,

\footnotetext{
4.15 Vienna Convention, 1983 . Article 6.

$+3^{\text {th }}$ Opinion No. I3, loc, cit, above (n. 8).

+17 Ibid., p. 1592 .

+3 Ibid.

1.1) Opinion No. 1, loc. cit above (n. 5).
} 
questions of State succession can be seen to be merely a specific species of problems that lie within the genus of issues of State responsibility. The point of distinction to which the Arbitration Commission appeared to refer is that whereas State responsibility primarily concerns the existence and consequence of illegal acts in international law, State succession is concerned with the 'transfer' of that responsibility or its 'assumption' by a successor State. When looked at from the point of view of successor States, however, one might question whether there is a great difference between the attribution of responsibility following a rule of succession and its attribution directly in virtue of the principle of pacta sunt servanda or other principles of customary international law.

The obvious point in the context of war damages was whether, and to what extent, the various Republics were responsible for the damage caused in the months of conflict that started in mid-199I and continued thereafter. Although it was clearly preferable, from a pragmatic point of view, to separate the question of war damages from that of the more general question of succession, in so far as the identity of the various parties in that period was unclear the question would clearly arise as to whether any one of the Republics could be held responsible for the tortious acts committed in the name of the SFRY. That this is not merely a remote possibility is highlighted by the fact that the SFRY was not, in the opinion of the Arbitration Commission at least, defunct until July 1992, by which time a considerable amount of fighting had already taken place. A point that the Arbitration Commission might have made, however, is that it is a general principle in the law of succession that a successor State is not liable for the delicts of its predecessor. ${ }^{+40}$ Accordingly, if the claims for war damages in question were of a strictly unliquidated nature, even if they were attributable to an act of the SFRY itself, they would not pass to the successor State and would therefore not be relevant as regards the division of assets and liabilities. In essence, this would render the same conclusion as that offered by the Arbitration Commission, but would achieve it by a more consistent line of reasoning.

\section{CONCLUSIONS}

It is undoubtedly the case that the opinions of the Arbitration Commission, taken as a body, represent a unique and important examination of the legal issues that attach to the dismemberment of a State. It has rarely been the case that an independent body of legal experts has been asked to consider the whole range of issues relating to statehood,

t+o Robert E. Broun case, Annual Digest, vol. 2, No. 35. There is some doubt whether the principle can be strictly applied: see Lighthouses arbitration, 23 ILR 81 ; O'Connell, op. cit. above (n. 121 ), vol. 1, pp. $482-6$. 
recognition, self-determination, territorial integrity, and succession, in relation to the break-up of a single State, and to map their development as events unfold. It is equally rare for a quasi-judicial body to play such an active part in the process of dismemberment itself. As has been noted, even if the opinions of the Arbitration Commission were delivered in a consultative capacity (a point which was not entirely clear in the early stages) and for that reason are not to be regarded as res judicata, they nevertheless played an influential part in creating the necessary framework within which subsequent State practice developed. It is particularly clear, for example, that the Arbitration Commission's first opinion, in which it found the SFRY to be 'in the process of dissolution', not only set the scene for the subsequent recognition of the emergent Republics, but also provided the impetus for the subsequent exclusion of the FRY from automatic membership in international organizations.

The precise role and terms of reference of the Arbitration Commission was particularly unclear in the early stages of its work. It was created pursuant to an agreed statement adopted at the opening session of the International Conference for Peace in Yugoslavia, at which it was determined that an arbitral procedure should be established to which the relevant authorities would be competent to submit their differences. Thereafter, however, it did not undertake a normal process of arbitration: no compromis was agreed for the submission of disputes to the Commission, and no awards were delivered. Instead, the Commission delivered a series of 'opinions' as an advisory, or consultative, body to the Chairman (or later the Steering Committee) of the Conference. It also delivered a number of opinions relating to questions of recognition that had been submitted to it by the Council of Ministers of the EC.

Although its terms of reference were later revised and made more explicit, the jurisdiction of the Arbitration Commission was still challenged on two occasions by the FRY. On each occasion, the Arbitration Commission dismissed the challenge and continued to deliver the opinions as requested. In doing so, it drew heavily upon the case law of the $I C J$ in respect of its advisory jurisdiction. It has been argued that there are cogent reasons for distinguishing between the advisory jurisdiction of the ICJ and that of the Arbitration Commission or other bodies similarly positioned. With respect to all permanent tribunals which operate an advisory jurisdiction as part of their participation in the activities of the Organization to which they are responsible, it is clear that that jurisdiction is materially related to the object and purpose of the Organization as a whole. If, as in the case of the ICJ, there is a close, 'organic', relationship between the Court and the Organization, it is acceptable to presume that member States have consented to the jurisdiction of the Court to the extent to which the role of the Court is concerned with the purposes of the Organization. If, however, there is no clear organic relationship (as in the case of the PCIJ), or the object and 
purpose of the organization (or indeed the tribunal itself) are obscure, the chain of consent cannot lightly be presumed. In other words, it would be highly inappropriate for an institutional tribunal to offer an opinion on a question that related to the substance of a dispute between States without their explicit consent, unless it was apparent that consent could be imputed through the existence of a clear institutional interest. Whether or not that is the case is dependent both upon the terms of the constituent instrument and the extent to which the organization has international personality in its own right in which its interest may be developed. In the case of the Arbitration Commission, it is doubtful whether the independent interest of the Conference could be materially demonstrated as regards questions relating to the statehood of the FRY, particularly in so far as the distinct identity of the Conference could scarcely be discerned.

Notwithstanding the possible doubts regarding its jurisdiction, the Arbitration Commission produced a series of opinions which have important implications for the development of public international law. Some of the main points that can be drawn from an analysis (and in some instances a development) of its conclusions are as follows:

I) When a State loses the majority of its population and territory through the involuntary disassociation of one or more territorial units, so that the remaining entity is forced to reconstitute itself constitutionally, it may be presumed to have suffered dismemberment. Despite the suggestions of the Arbitration Commission, it is considered that the determinants of this process do not (and should not) change according to the type of government that is exercised over the territory, whether that be unitary or federal. Equally, it is considered that whether or not the material facts point towards the dismemberment or continuation of the State may ultimately be confirmed or denied by the individual appreciation of the States concerned, and that of other members of the international community. It cannot be sustained, particularly in light of the case of Bosnia-Herzegovina, that the legal function of diplomatic recognition is 'purely' declaratory.

2) If a State is identified as being in the process of dismemberment (i.e. that a majority of the constituent territorial units, which embody the majority of the population, have undertaken to disassociate themselves from the parent State), no presumption will be operated in favour of the continued effectiveness of the parent State. Accordingly, the entities that emerge therefrom will be able to establish their sovereignty and statehood with greater ease than would be the case if they had merely seceded. Whilst this does not mean that the parent State has technically transferred its sovereignty over the territory concerned to the emergent entities, it may otherwise be assimilated to a case of devolution, at least as far as the emergent States are concerned. 
3) Whereas in cases of secession, the identity of the nascent State will be relatively clear, that is not necessarily the case with respect to dismemberment which, as a process, does not identify per se the presumptive units for future statehood. That, however, is to be determined not by resort to the principle of self-determination, nor by a strict application of the principle of effectiveness, but rather in virtue of the principle of uti possidetis juris. In this context, uti possidetis operates not merely to seal the boundaries of the emergent entities, but also serves to distinguish between those entities that have a right to territorial sovereignty and those that do not. In other words, independent territorial units that exist within the borders of a former administrative unit have to establish their statehood as against the presumptive effectiveness of the unit as a whole. This rule is not affected by the application of the principle of self-determination.

4) All successor States are bound by peremptory norms of international law relating to the rights of peoples, individuals and (possibly) minorities, and the principle of self-determination requires all successor States to allow every individual a right to choose to belong to the ethnic, religious or language community of his or her choice (subject to the necessary interests of the community). More doubtfully, it may also entail a right of individual members of minorities to choose their nationality.

5) All States emerging from a process of dismemberment are equal successors in title, and a fortiori, none of them can be considered to be the continuation of the former parent State. All successor States are under an obligation to enter into negotiations with a view to achieving an equitable distribution of the assets and liabilities of the parent State. Failure to co-operate to that end may invoke the international responsibility of the State concerned, and any State suffering loss is entitled to take nonforcible counter-measures in accordance with international law.

6) In the distribution of assets and liabilities, immovable property on the territory of the successor States is subject to the principle of the locus in quo. This is also, but more doubtfully, the case in respect of movable property. As regards other State property, archives and debts, including that on the territory of third States, they should be distributed among the successor States according to the principle of equitable apportionment. That principle itself does not require division according to equal proportions, but merely that the division should be broadly equitable.

These broad principles, which form the heart of the Arbitration Commission's opinions, are by no means without their problems and in places are obscured by some of the Commission's own reasoning. The approach of the Commission, on occasion, tended to be excessively rigid and deterministic, particularly as regards its findings in respect to statehood. On other occasions it adopted an over-ambitious approach, as for example in its views in respect of the content of jus cogens. In many 
instances, however, the Commission was attempting to deal with the very difficult and specific problems that arose in relation to the events in Yugoslavia, and for that reason, even if its views cannot always be accepted as general, and universal, propositions, they may nevertheless provide an indication as to the direction in which the various aspects of international law are developing. 